\title{
FRUITS OF THE AMAZONIAN FOREST. PART II: SAPOTACEAE
}

\section{Marc G.M. VAN ROOSMALEN' ${ }^{\prime}$, Olímpia Maria da Cruz Gomes GARCIA'}

\begin{abstract}
Descriptions and line drawings of fruits and seeds from 153 woody species of the family Sapotaceae occurring in Amazonia are presented, along with their preferred habitat, distribution, habit and seed dispersal.
\end{abstract}

Key words: Amazonia; Sapotaceae; fruits; morphology; ecology; seed dispersal.

Frutos da Floresta Amazônica. Parte II: Sapotaceae

RESUMO - Descrições e desenhos de frutos e sementes de 153 espécies da familia Sapotaceae na Amazônia Legal são apresentadas, com informações sobre o hábito, habitat, distribuição geográfica e dispersão de sementes de cada espécie.

Palavras-chave: Amazônia; Sapotaceae; frutos; morfologia; ecologia; dispersão de sementes.

\section{INTRODUCTION}

This is the second contribution to a series of articles in which we pretend to describe and illustrate the fruits of all woody plants occurring in the Amazonian forest. The first article treating the fruits of the family Myristicaceae was published in December 1996 (Van Roosmalen et al., 1996). It is estimated that at least 10,000 species of trees, shrubs, lianas, twiners and hemi-epiphytes occur in lowland Amazonia, five times as many as have been included in the Field Guide to the Fruits of the Guianan Flora (Van Roosmalen, 1985).

Each contribution contains detailed descriptions of fruits and seeds, and information on geographical distribution, habit, preferred habitat, seed dispersal and seed predation. Moreover, when data on zoochory and feeding habits are available, the animals are mentioned which are involved in seed dispersal, seed predation and seedling browsing of the plant species.
Simple descriptions of leaves and inflorescences are included which may add to identification of the fruits in the field.

\section{METHODS}

The descriptions and drawings of fruits and seeds are based on plant material from various herbariums, most importantly of the National Institute for Amazon Research (INPA), Manaus, Brazil, the University of Utrecht, Holland, the University of Paramaribo, Suriname, and the collection of fruits preserved, either dry or in spirit, FAA or glycerol, kept by the first author at INPA.

With respect to the taxonomy, the authors follow the specialist on the Sapotaceae, Dr. T.D. Pennington, who revised the family in 1990 . Descriptions of leaves, inflorescences and flowers are generally taken from his revision and from the Field Guide to the Fruits of the Guianan Flora (Van Roosmalen, 1985).

For representative collections examined for these descriptions we

1 Instituto Nacional de Pesquisas da Amazônia - INPA, Av. André Araujo, 1756-Aleixo, 69083 Manaus, AM. e-mail roosmale@internext.com.br 
refer to both authors mentioned here. References for the collections used for illustrating the fruits and seeds are given in the legends of each plate.

The main collecting areas in the vicinity of Manaus were: Rio TarumãAçú, the Anavilhanas Archipelago, Marchantaria Island, the cattle ranches where the WWF/Smithsonian/INPA project is taking place $(80 \mathrm{~km}$ north of Manaus), the Adolfo Ducke Forest Reserve (AM-010, km 25), and the Rio Cuieiras Nature Reserve (BR-174,

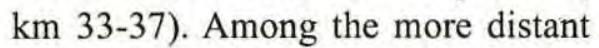
areas where fruits were collected, are: Rio Tefé, Rio Juruá, Rio Urucú, Rio Negro, Rio Jauaperí, Rio Cauaburi (Pico da Neblina National Park), Rio Abacaxis, Rio Maués-Açú, Rio Madeira, Rio Aripuanã, and Rio Uraricuera (Maracá Island). Illustrations of fruits were made preferably from fresh material or from fruits collected fresh and preserved in FAA, $70 \%$ ethanol, $10 \%$ formol or $50 \%$ glycerol.

Many hitherto unpublished data are included from fieldwork carried out by the first author on the ecology of primates and other vertebrates in Suriname (1976-1979), French Guiana (1983-1985) and Brazil (1987- ).

All illustrations of fruits and seeds are drawn natural size (1:1).

For a glossary of botanical terms, please refer to the appendix published in Van Roosmalen et al. (1996). For abbreviations, please refer to the introduction of Van Roosmalen et al. (1996).

\section{SAPOTACEAE A.L. de Jussieu}

Leaves spirally arranged, or al- ternate and distichous, sometimes opposite or verticillate, simple, entire, with large caducous stipules in all species of Ecclinusa and Chromolucuma, leaving an obvious scar. Inflorescences fasciculate, axillary, ramiflorous or cauliflorous, often being densely clustered on twigs, branches or trunk, or occasionally several arranged along short leafless axillary shoots; flowers bisexual or unisexual (the plant monoecious or dioecious), small, regular, 36(-7)-merous, the calyx with a single whorl of (4-)5(-6) free, imbricate sepals (as in most Pouteria spp.), or with 6-12 spirally arranged sepals (as in Pouteria section Aneulucuma), or biseriate, consisting of 2 whorls, each with (2-)3-4 sepals (as in Manilkara); petals more or less connate, cyathiform or shortly tubular, usually with included stamens (as in most Pouteria spp.), or with widely spreading lobes (rotate) and exserted stamens (as in Pradosia); ovary superior, 1-15locular with uniovulate loculi, but reduced to 3,2 or 1 locule in many Pouteria spp. (Diploön has 1 locule with 2 basal ovules); styles 1 . Fruit a berry with an undifferentiated endocarp, or, as in Pradosia, a drupe with a cartilaginous endocarp, globose, ovoid, obovoid, or ellipsoid, the small-fruited species often with a soft pericarp, the larger-fruited species often with a leathery and hard pericarp, with the innermost 1-3 mm surrounding the seed being a succulent sweet watery jelly, the fleshy part always edible and sweet-tasting, the pericarp indehiscent (only dehiscent in some Chrysophyllum spp.); seeds 1-several, 
very distinctive, the family characteristic being the smooth shining brown testa contrasting with the conspicuous pale rough scar (hilum) by which the seed is attached to the rest of the fruit, the seed shape, position of the scar, and extent of the scar provide useful taxonomic characters; many species have strongly laterally compressed seeds (e.g., Chrysophyllum spp., Manilkara spp.), or broadly ellipsoid seeds with a narrow or broad adaxial scar ( many Pouteria spp.), or broadly ellipsoid, subglobose or obovoid seeds with a small or large basal or basi-ventral scar (Diploön, some Chrysophyllum spp.).

Notes. Small to large trees, with a cylindrical bole (in all Manilkara spp.) or fluted bole (as in many Pouteria spp.), the base of the trunk often buttressed, the bark rarely smooth, often fissured or scaling, with white, rarely yellow, rather thick, sticky or at least milky latex in trunk, branches and young fruit; pollination by bats (as in Manilkara spp.), small bees and other insects (in Pouteria spp.), and flies and maybe larger vertebrates (such as Caluromys) in Pradosia spp.; seed dispersal, at least in the small-fruited species with a soft pericarp, by birds (cotingids, toucans, guans), and monkeys (the family is probably the most important food-supplier for most of the 16 genera of Neotropical primates), the smaller and larger seeds swallowed and endochorically dispersed by spider monkeys (Ateles), woolly spider monkeys (Brachyteles), woolly monkeys (Lagothrix), howling monkeys
(Alouatta), capuchin monkeys (Cebus), titi monkeys (Callicebus), the small seeds also dispersed by small monkeys such as night monkeys (Aotus), squirrel monkeys (Saimiri), lion tamarins (Leontopithecus), tamarins (Saguinus and Callimico), marmosets (Callithrix), and pygmy marmosets (Cebuella), furthermore coatis (Nasua), kinkajous (Potos), marsupials (Didelphis and Caluromys), fish (some igapó and várzea species might be dispersed by fish), tortoises (Geochelone), and bats (only some soft skinned, sweet fruited species with a seed easily removed from the pericarp); predation of the immature seeds of almost all Sapotaceae is common in parakeets, parrots, and macaws, and very common in pithecine monkeys, such as bearded sakis (Chiropotes), sakis (Pithecia), and uacaries (Cacajao), often leaving very few seeds to mature and to be dispersed.

\section{Chromolucuma Ducke}

Leaves spirally arranged, stipules present, large, leaving a conspicuous scar. Flowers unisexual, pedicellate; sepals 5 . Fruit containing one seed, testa dull and rough, scar broad adaxial covering up to two thirds of the seed.

Notes. Trees with yellow latex.

Distribution. Two species in South America.

\section{Chromolucuma baehniana Monachino}

Leaves sericeous below, with 1326 pairs of secondary veins. Fascicles 2-6-flowered, axillary and below the leaves; pedicels $0.5-0.9 \mathrm{~cm}$ long; flow- 
ers unisexual. Fruit velvety-chestnut when young.

Notes. Tree to $30 \mathrm{~m}$ high, trunk diameter to $70 \mathrm{~cm}$, buttresses to $3 \mathrm{~m}$ high, bole fluted, with scaling reddishbrown bark; dry evergreen forest over white sand, also along creeks.

Distribution. Brazil (NW Amazonas: Pico da Neblina National Park), Guyana, Venezuela (Amazonas).

\section{Chromolucuma rubriflora Ducke}

abiurana-do-chavascal, abiuranagrande-de-igapó, majá, sapota-brava (B) Pl. 1, fig.1

Leaves glabrous, with 17-40 pairs of secondary veins. Fascicles many-flowered, below the leaves; pedicels $1.5-3.7 \mathrm{~cm}$ long; flowers unisexual. Fruit broadly ellipsoid to ovoid, $5.5 \times 4.5 \mathrm{~cm}$, to $8 \mathrm{~cm}$ long, rounded at base and apex, smooth or rugose (when immature dried strongly and irregularly ribbed and furrowed), ferrugineous brown shortly velutinous, becoming subglabrous at maturity; seed ellipsoid, sometimes 2-seeded and then planoconvex, $2.5-5.5 \mathrm{~cm}$ long, or $3.5 \times 2.9 \mathrm{x}$ $2.0 \mathrm{~cm}$, rounded at base and apex, apex with stout prickle, testa caniculately furrowed, scar $3.5 \times 2.7 \mathrm{~cm}$.

Notes. Tree to $30 \mathrm{~m}$ high, trunk diameter to $40 \mathrm{~cm}$, buttressed; immature seeds were seen eaten by Humboldt's black-headed uacaris (Cacajao melanocephalus melanocephalus) along R. Cauaburi (Pico da Neblina National Park, Brazil)(Boubli, 1997), mature fruits were seen eaten and the seeds dispersed by woolly monkeys (Lagothrix lagotricha lagotricha) along $\mathrm{R}$. Apaporis, Colombia (Defler, pers. comm.); periodically flooded forest along riversides, and dry evergreen forest over white sand.

Distribution. Brazil (Amazonas, Pará), Colombia, Venezuela (Amazonas).

\section{Chrysophyllum Linnaeus}

Leaves spirally arranged, or alternate and distichous. Inflorescences axillary, ramiflorous or cauliflorous; flowers unisexual or bisexual, fasciculate, rarely solitary, calyx a single whorl of (4-)5(-6) sepals, sometimes accrescent in fruit. Fruit a 1 - to manyseeded berry, sometimes dehiscent; seeds laterally compressed, with a narrow adaxial scar, sometimes extending around the base of the seed, or not laterally compressed and then the scar broader, basi-ventral or adaxial, testa smooth and shining, or rough and then adherent to the pulp.

Notes. Trees or shrubs.

Distribution. Pantropical genus with ca. 43 species in the Neotropics.

Chrysophyllum section 1.

\section{Chrysophyllum}

Leaves spaced, usually alternate and distichous. Fascicles mostly axillary; flowers bisexual; sepals not accrescent in fruit. Seed not or only rarely laterally compressed, usually with a broad basi-ventral or adaxial scar, testa smooth, shining, free from pericarp.

Chrysophyllum argenteum Jacquin subsp. auratum (Miquel) Pennington

sururuburuen(A); pinto-boletri

(S); rosada-brava, abiurana-batinga

(B) Pl. 1, fig. 2

Leaves golden sericeous below, 
with (8-)10-16(-25) pairs of secondary veins. Fascicles (2-)5-15(-25)-flowered; pedicels (0.2-)0.3 cm long; sepals 5 ; fruits solitary or in pairs on $0.4-0.5 \mathrm{~cm}$ long pedicels. Fruit ellipsoid, $2-2.5 \times 1.5-2 \mathrm{~cm}$, smooth, glabrous, at first green to yellow, eventually reddish to purplish-black, shining; pericarp fleshy, sweet-tasting; seeds 1 , slightly to strongly laterally compressed, scar usually heartshaped, basi-ventral, about half the length of the seed.

Notes. Tree to $35 \mathrm{~m}$ high, trunk diameter to $65 \mathrm{~cm}$, with small rounded buttresses and fluted bole, slash pink or reddish, exuding copious sticky white latex; in Suriname, the author saw the mature fruits being eaten and the seeds dispersed by golden-handed tamarins (Saguinus midas midas), red howling monkeys (Alouatta seniculus) and black spider monkeys (Ateles paniscus), whereas the immature seeds were heavily predated upon by black bearded sakis (Chiropotes satanas chiropotes); lowland tropical rainforest, montane and cloud forest, along riverbanks and sometimes in flooded forest (igapó).

Distribution. Brazil (Acre, Amapá, Amazonas, Pará, Roraima), Colombia, Guianas, Peru, and Venezuela.

Chrysophyllum argenteum Jacquin subsp. nitidum (G.F.W. Meyer) Pennington

\section{kokeritiballi (A)}

Leaves glabrous below, with (8) 10-16(-25) pairs of secondary veins. Fascicles (2-)5-15(-25)-flowered; pedicels (0.2-)0.3-0.7(-1) cm long; sepals (4-)5. Fruit violet when ripe, with copious latex in pericarp.

Notes. Tree to $25 \mathrm{~m}$ high with fluted bole; seasonal semi-evergreen forest, pioneer vegetation, high mixed wallaba forest, and dry Mora forest.

Distribution. Brazil (Pará), Guianas, Venezuela.

\section{Chrysophyllum cainito Linnaeus}

sterappel, starápra (S); caimito (B) Pl. 1, fig. 3

Leaves golden(- ferrugineous) sericeous below, with 14-26 pairs of secondary veins. Fascicles dense, 520(-30)-flowered; pedicels $0.6-1.2 \mathrm{~cm}$ long; sepals (4-)5(-6), sometimes persistent in fruit, red-sericeous. Fruit broadly ellipsoid to globose, to 7.5 (12) $\times 6.5(-8) \mathrm{cm}$, green to purplish, apex and base obtuse to rounded, smooth, glabrous; pulp white, translucent, sweet-tasting; seeds 3-10 (some abortive), $1-1.8 \mathrm{~cm}$ long, usually laterally compressed, brown, with a smooth shining testa, scar adaxial, 0.6$1.3 \mathrm{~cm}$ long, always more than half the length of the seed, about equalling the width of the seed, often with a small rounded beak near the apex; cross section of fruit shows stellately arranged locules, hence the name 'starapple'.

Notes. Tree to $15(-25) \mathrm{m}$ high, with eventually slightly fluted bole, the bark deeply and narrowly fissured; lowland, riverine and montane forest.

Distribution. Widely cultivated and naturalized throughout Central and South America, probably native only in the Greater Antilles.

Chrysophyllum section 2.

Villocuspis A. de Candolle 

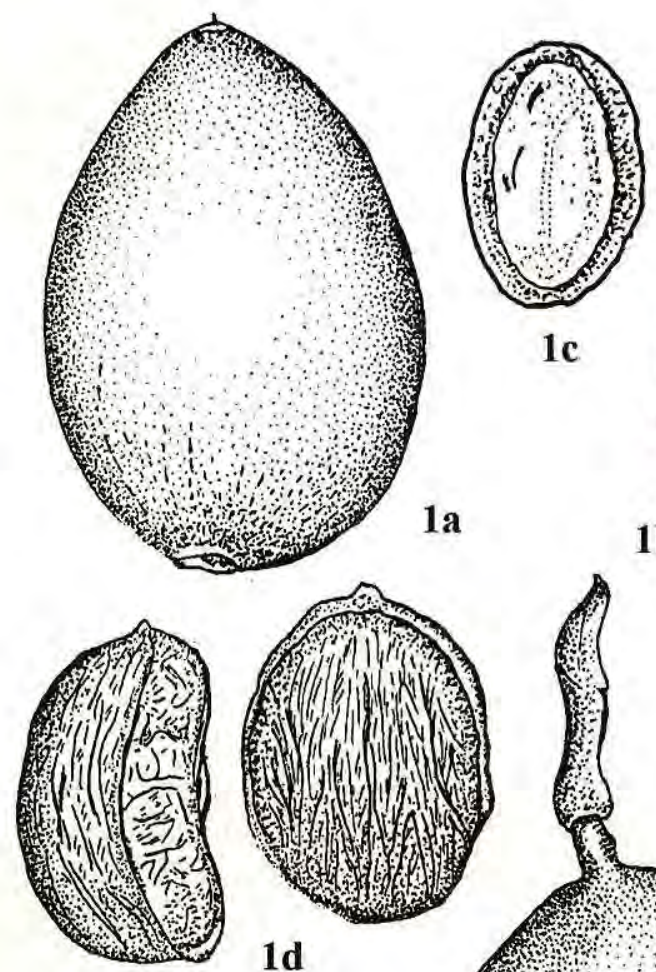

1d
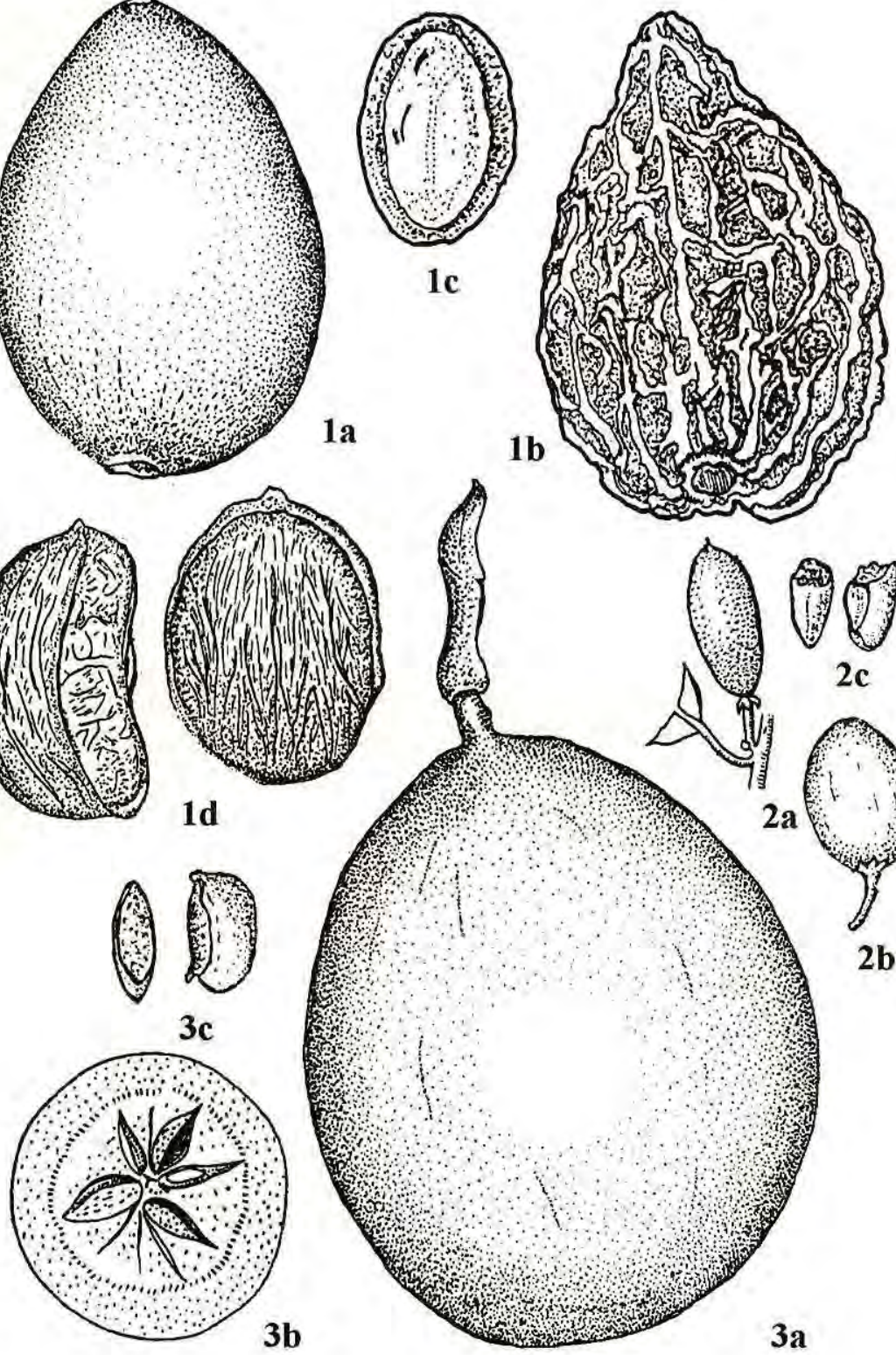
Leaves spaced, alternate and distichous. Fascicles axillary; flowers bisexual, only unisexual in $C$. sparsiflorum; sepals not accrescent in fruit. Seed not laterally compressed, scar broad, adaxial or basi-ventral, testa smooth, shining, free from pericarp.

\section{Chrysophyllum sparsiflorum}

Klotzsch ex Miquel in Martius fig. 1

abiurana, mangabarana (B) Pl. 2,

Leaves at first pale sericeous below, glabrescent, with 11-16 pairs of secondary veins. Fascicles $2-6$-flowered, sepals (4-)5, in fruit $0.15 \mathrm{~cm}$ long; pedicels $0.15-0.5 \mathrm{~cm}$, in fruit $0.5-1.0 \mathrm{~cm}$ long. Fruit ellipsoid or obovoid, to $3.0 \times 2.2 \mathrm{~cm}$, apex rounded, apiculate, base rounded or slightly tapered; smooth, glabrous, maturing yellow; pericarp fleshy; seed solitary, ellipsoid, plano-convex, $1.3 \mathrm{~cm}$ long to $2.0 \times 1.2 \mathrm{~cm}$, testa smooth, shining, very hard and woody, scar broad, covering the adaxial face, 1.1-2.0 $\times 0.8$ $0.9 \mathrm{~cm}$.

Notes. Tree to $25 \mathrm{~m}$ high and 75 $\mathrm{cm}$ diam., bark containing white milky latex; terra-firme lowland rain and savanna forest.

Distribution. Bolivia, Brazil (Mato Grosso, Pará, Rondônia), Guyana, Venezuela.

\section{Chrysophyllum Section 3. Ragala}

(Pierre) Pennington

Leaves spaced or clustered at the shoot apex, spirally arranged. Fascicles ramiflorous; flowers bisexual or unisexual; sepals usually accrescent in fruit. Fruit with moderately to strongly laterally compressed seeds, scar usually narrow, extending along the adaxial face and around the base, testa smooth, shining, free from pericarp.

\section{Chrysophyllum bombycinum}

\section{Pennington}

coquirana (B) Pl. 2, fig. 2

Leaves tightly clustered, very big, with 25-30 pairs of secondary veins. Fascicles ramiflorous on older branches, 1-20-flowered; flowers bisexual; sepals 5, accrescent and thickened in fruit, to $1.2 \mathrm{~cm}$ long; pedicels $0.5-1 \mathrm{~cm}$ long. Fruit globose or obovoid, ca. $4 \times 3.5 \mathrm{~cm}$, apex truncate or rounded, base tapered, yellow to orange, smooth, glabrous; seeds several, ca. $2 \mathrm{~cm}$ long, strongly laterally compressed, scar ca. $0.15 \mathrm{~cm}$ wide.

Notes. Tree to $25 \mathrm{~m}$ high, with cylindrical bole, no buttresses; terrafirme forest, usually on white sand.

Distribution. Brazil Amazonas), Peru (Loreto).

\section{Chrysophyllum sanguinolentum}

(Pierre) Baehni subsp. balata

(Ducke) Pennington

abiurana, balata, coquirana, ucuquirana-brava (B) Pl. 2, fig. 3

Leaves very large, appressed ferrugineous or silvery puberulous below, with 15-21 pairs of secondary veins. Fascicles 10-20-flowered; flowers bisexual; sepals 5 , rounded, in fruit strongly accrescent and thickened (woody), two smaller sepals to $1 \times 1.2$ $\mathrm{cm}$, three larger ones to $1.5 \times 1.8 \mathrm{~cm}$; fruiting pedicels to $0.2 \mathrm{~cm}$ long. Fruit subglobose, to $3 \times 4 \mathrm{~cm}$, apex truncate or depressed, base rounded or truncate, yellow to pale brown, woody, longitudinally striate, with sunken prickle, 
smooth, glabrous or brown-sericeous; seeds 4-5, 1.4-2.5 cm long, laterally compressed, scar $0.1-0.15 \mathrm{~cm}$ wide.

Notes. Tree to $40 \mathrm{~m}$ high and 60 $\mathrm{cm}$ diam., sometimes with narrow twisted buttresses, bark greyish, fissured, with abundant white or creamcolored latex; commonly found in periodically flooded forest (várzea), but also in terra-firme forest; the tree is the source of an inferior 'balata' (rubber).

Distribution. Am. Colombia, Brazil (Amazonas, Pará), Guyana, Am. Peru, Am. Venezuela.

\section{Chrysophyllum sanguinolentum}

(Pierre) Baehni subsp.

\section{sanguinolentum}

barataballi (A); swit'anini (S); switi-amini (P); balata, ucuquirana verdadeira (B) Pl. 2, fig. 4

Leaves glabrous, with 8-10 pairs of secondary veins, petioles less than $2 \mathrm{~cm}$ long. Fascicles 10-20-flowered; flowers bisexual; sepals 5, rounded, in fruit weakly accrescent, less than $1 \mathrm{~cm}$ long, not or weakly thickened; fruiting pedicels $0.2-0.5 \mathrm{~cm}$ long. Fruit globose or ovoid, $4 \times 5$ to $6 \times 7 \mathrm{~cm}$, pale brown, brown-sericeous, epicarp hard, finally 5-valved dehiscent, pulp tough, pale greenish-cream, edible, sweettasting; seeds 4-5, ca. $1.8 \times 1 \times 0.7 \mathrm{~cm}$.

Notes. Tree to $40 \mathrm{~m}$ high and 60 $\mathrm{cm}$ diam., with steep, stout, simple buttresses to $75 \mathrm{~cm}$ high, trunk sometimes fluted, bark reddish or rustybrown, scaly, slash pink to red, exuding copious sticky white latex; in the past, the latex was employed as a substitute for rubber; in French Guiana (R. Arouany), the author saw black spider monkeys (Ateles paniscus) feeding frequently on the ripe fruits of this subspecies and these monkeys seemed to be the principal seed dispersers; terra -firme lowland forest and hill forest on brown sand.

Distribution. Brazil (Amapá), Guianas, S Venezuela.

\section{Chrysophyllum sanguinolentum}

(Pierre) Baehni subsp. spurium

(Ducke) Pennington

abiú, balata-brava, ucuquiranabrava, coquirana-brava (B) Pl. 3, fig. 1

Leaves medium-sized, glabrous, with $10-16$ pairs of secondary veins, petiole 2-4 cm long. Fascicles 10-20flowered; flowers bisexual; sepals 5 , rounded, in fruit weakly accrescent, less than $1 \mathrm{~cm}$ long, not or weakly thickened, three sepals coalescent, 0.3$0.5 \times 0.8-1.2 \mathrm{~cm}$, two smaller ones $0.2-0.3 \times 0.6-0.7 \mathrm{~cm}$; fruits on wartlike outgrowths on leafless branches and twigs, pedicels stout, $0.3-0.5 \mathrm{~cm}$ long. Fruit obovoid, $5 \times 3.5$ to $8.5 \times 7.3 \mathrm{~cm}$, yellowish to brown, with light brown indumentum, apex sunken with minute prickle, longitudinally striate to obscurely ribbed; seeds $2-5,1.8 \times 1 \times 0.7$ $\mathrm{cm}$ to $2.7 \times 1.3-1.5 \times 1 \mathrm{~cm}$, glossy brown-black, scar linear, to $2.1 \mathrm{~cm}$ long, extending to $0.7 \mathrm{~cm}$ around the base.

Notes. Tree to $35 \mathrm{~m}$ high and 50 $\mathrm{cm}$ diam. with small buttresses, the slash exudes copious thick white or yellowish latex; immature seeds are seen eaten by parrots and pithecine monkeys (Pithecia pithecia chrysocephala and Chiropotes satanas chiropotes), the black bearded sakis heavily predating on the young seeds from June to November in the vicinity of Manaus, Amazonas, whereas 


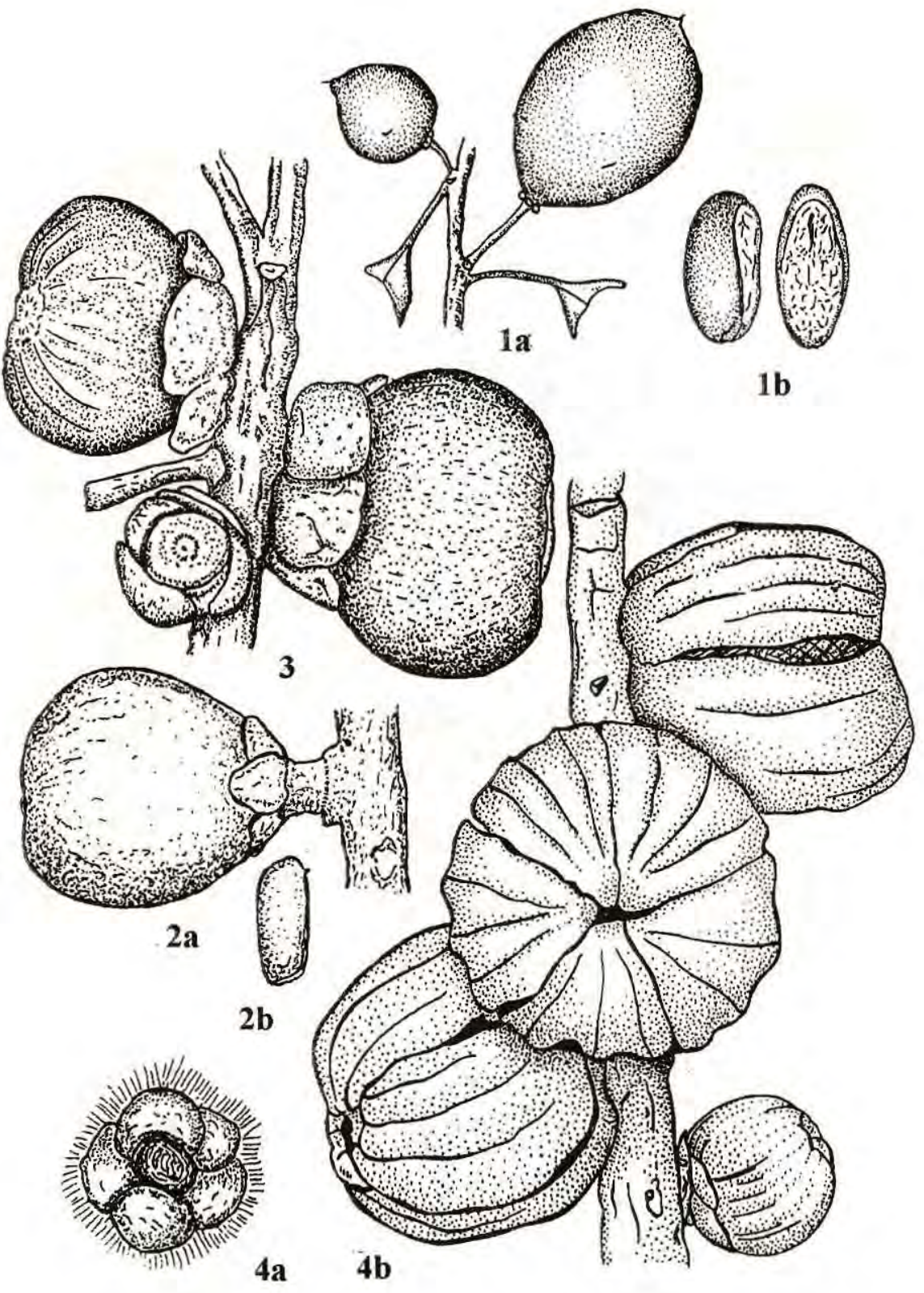

PI. 2. Figs. 1-4. SAPOTACEAE. 1. Chrysophyllum sparsiflorum, a. young and mature fruit; b. seed, lateral and frontal view (Steyermark 60975). 2. C. bombycinum, a. fruit; b. seed (Gentry \& Aronson 25302). 3. C. sanguinolentum subsp. balata, infructescence (Van Roosmalen 47), 4. C. sanguinolentum subsp. sanguinolentum, a. fruiting calyx from below; $b$. infructescence, the mature fruits dehiscing (Van Roosmalen 2320). 

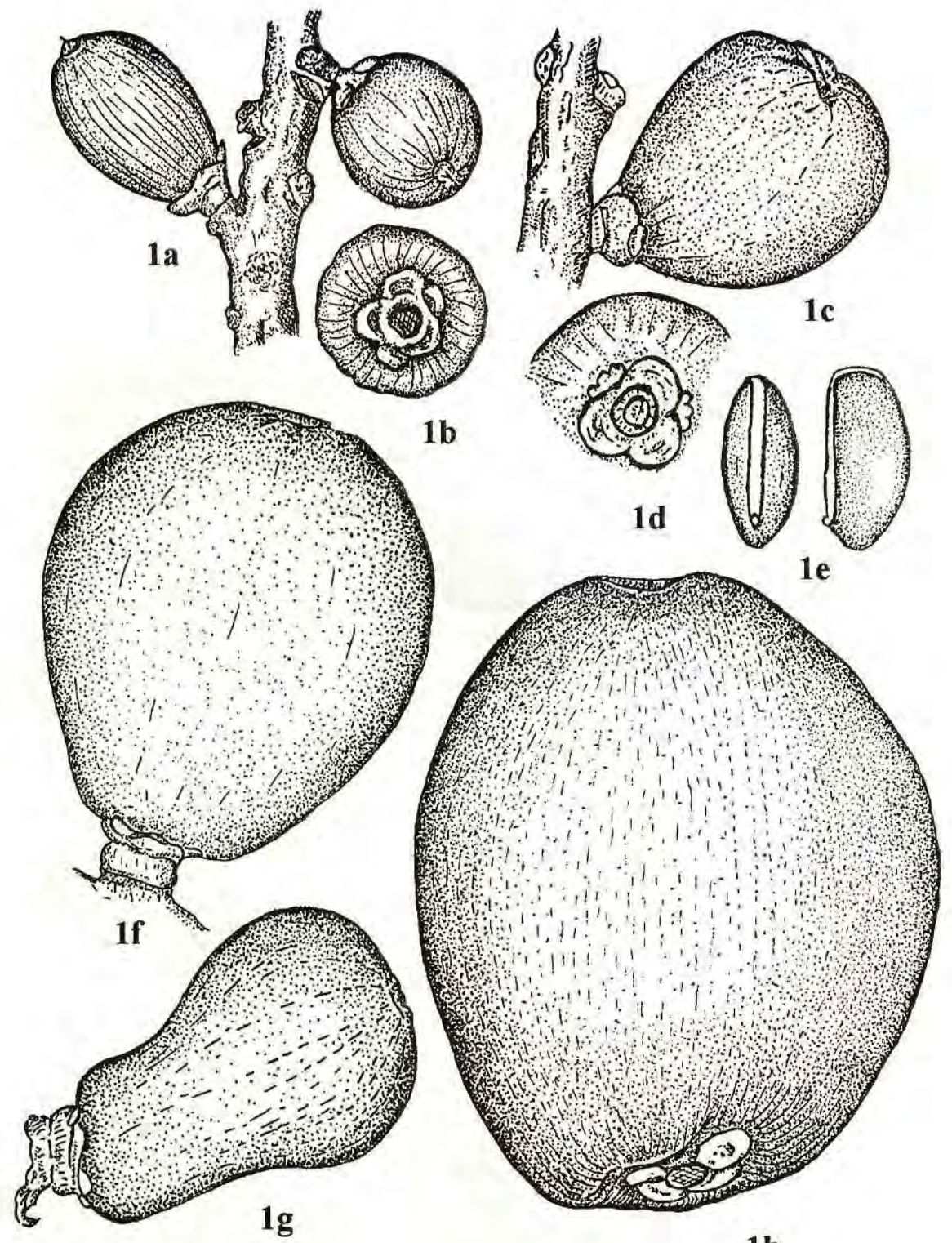

1h

Pl. 3. Fig. 1. SAPOTACEAE. 1. Chrysophyllum sanguinolentum subsp. spurium, a. young infructescence; b. young fruit from below; c. young fruit; $d$. fruit from below; e. seed, frontal and lateral view; f. mature fruit; g. mature fruit; h. mature fruit (Peres 513, 471, 473). 
capuchin monkeys (Cebus albifrons) were observed eating the ripe pulp of this subspecies, dominating the forest on the lower slopes of the Pico da Neblina (Boubli, pers. comm.); in the R. Urucú region (Amazonas, Brazil), Geoffroy's woolly monkeys (Lagothrix lagotricha cana) are reported to feed on mature fruits, dispersing the seeds endochorically, but also predating on the immature seeds (Peres, 1994), whereas capuchin monkeys (Cebus apella) and buffy sakis (Pithecia albicans) were seen eating the ripe fruits, and buffy sakis also the immature seeds (Peres, pers. comm.); ripe fruits weigh 85-102 grams; frequently present in periodically flooded lowland forest (várzea), but also in terra-firme, savanna and montane forest.

Distribution. Brazil (Acre, Amazonas), Am. Colombia, Am. Peru, S. Venezuela.

\section{Chrysophyllum ucuquirana-branca}

(Aubréville \& Pellegrin) Pennington

balata -brava, coquirana-branca, coquirana-rocha (B) Pl. 4, fig. 1

Leaves large, densely clustered at the shoot apex, spirally arranged, densely and persistently ferrugineous tomentose mixed with short crisped hairs below, with 17-18 pairs of secondary veins. Fascicles many-flowered, flowers (sub)sessile, unisexual; sepals $5,0.5 \mathrm{~cm}$ long, densely villose, in fruit accrescent, three larger ones rounded, to $1.7-2 \times 1.8-2.2 \mathrm{~cm}$, two smaller ones $0.6-0.9 \times 1-1.2 \mathrm{~cm}$, thickcoriaceous, glabrescent; fruits sessile, clustered below leaves on old branches and twigs. Fruit subglobose, $3.8 \times 4.7$ to $5.5 \times 6.0 \mathrm{~cm}$, apex depressed, densely rufous-villose, the pubescence easily falling off, the pericarp ca. 0.7 $\mathrm{cm}$ thick, hard-woody; fruits weighing on average 55 grams; seeds 5 , often a few abortive, ovoid or ellipsoid, moderately laterally compressed, 1.7-2.5 x 1-1.4 x 0.7-1 cm, obtuse, lightbrown, shining, irregularly grooved, scar narrowly oblong or linear, 1.2-2.4 x 0.2 $0.4 \mathrm{~cm}$, extending around the base; seeds weighing on average 2 grams.

Notes. Tree to $28 \mathrm{~m}$ high and 43 $\mathrm{cm}$ diam., slash exuding white latex; golden-faced sakis (Pithecia pithecia chrysocephala) predate on the immature seeds north of Manaus, Amazonas (Setz, 1993); in the R. Urucú region, Brazilian Amazon, Geoffroy's woolly monkeys (Lagothrix lagotricha cana), buffy sakis (Pithecia albicans), and Amazona parrots were seen feeding on the immature pulp and seeds, whereas tufted capuchins (Cebus apella) and white-fronted capuchins (Cebus albifrons) fed on the mature pulp (Peres, 1994); terra-firme lowland forest, also on sandy soil.

Distribution. Brazil (Amazonas), Venezuela (Amazonas).

Chrysophyllum section 4. Prieurella (Pierre) Pennington

Leaves nearly always clustered at the shoot apex, spirally arranged. Fascicles ramiflorous or cauliflorous; flowers unisexual, sepals not accrescent in fruit. Fruit with moderately to strongly laterally compressed seeds, scar usually narrow, adaxial, testa rough, not shining, adherent to the pulp.

Chrysophyllum amazonicum

Pennington

abiú-da-mata, abiurana-massa- 
randuba (B) Pl. 4, fig. 2

Leaves glabrous, with 10-13(-16) pairs of secondary veins. Fascicles ramiflorous, 5-many-flowered; pedicels $0.5-0.8 \mathrm{~cm}$ long, in fruit ca. $1.2 \mathrm{~cm}$ long, stout; fruiting calyx 5 merous, sepals $0.2 \times 0.3 \mathrm{~cm}$, apex rounded. Fruit obliquely obovoid (when 1-seeded), $3 \times 2 \mathrm{~cm}$, or obscurely 2-3-lobed ellipsoid (when 2-3-seeded), $3.5 \times 3.7 \times 3 \mathrm{~cm}$ to $4.5 \times 3.8 \times 3.5 \mathrm{~cm}$, apex rounded, base rounded to acute, greenish-brown to yellow to orange brown, smelling after almond, smooth, glabrous, covered with conspicuous pale lenticels, prickle oblique; ripe fruits weigh on average 7.5 grams $(n=7)$; seeds 1-2(-4), laterally compressed ellipsoid, to $2.6 \times 1.5 \times 0.9 \mathrm{~cm}$, testa not shining, adherent to pulp, scar narrow, $2.1 \times 0.2-0.3 \mathrm{~cm}$, extending most of the length of the seed.

Notes. Tree to $45 \mathrm{~m}$ high and 54 $\mathrm{cm}$ diam., with up to $2 \mathrm{~m}$ high buttresses and fissured bark; in Colombia (R. Apaporis), ripe pulp seen eaten by Humboldt's woolly monkeys (Lagothrix lagotricha lagotricha) and seeds dispersed endochorically (Defler, pers. comm.); crops superabundant, one tree produced 10,700 mature fruits (Defler, pers. comm.); in the R. Urucú region, Amazonas, Brazil, tufted capuchins (Cebus apella) fed on ripe pulp (Peres, pers. comm.); immature seeds were seen eaten by pithecine monkeys (Chiropotes satanas chiropotes and Pithecia pithecia chrysocephala) north of Manaus, Amazonas (Frazão, 1992; Setz, 1993); terra-firme lowland forest and savanna forest on sandy soil.
Distribution. Brazil (Acre, Amazonas, Pará), Am. Colombia and Peru, S Venezuela.

\section{Chrysophyllum cuneifolium}

(Rudge) A. de Candolle

kwatabobi, atakamara (S); wilapele (P) Pl. 4, fig. 3

Leaves with 12-19 pairs of secondary veins. Fascicles cauliflorous on trunk and ramiflorous, many-flowered; pedicels $0.8-1.5 \mathrm{~cm}$, in fruit $1.5-2 \mathrm{~cm}$ long; fruiting calyx lobes $4-5$, recurved, $0.3-0.5 \mathrm{~cm}$ long. Fruit ellipsoid, obovoid or obconical, 2.8-4 x $2.5-3.2 \mathrm{~cm}$, sometimes to $5 \times 4 \mathrm{~cm}$, apex rounded or obtuse, apiculate, base tapered, mature yellowish to orange, smooth, glabrous or with some golden-yellow residual indumentum; seeds (3-)4-5, ellipsoid, $1.9-2.5 \mathrm{~cm}$ long, laterally compressed, brown, testa not shining, adherent to the pulp, scar extending most of the length of the seed, $0.15-0.2 \mathrm{~cm}$ wide.

Notes. Tree to $20 \mathrm{~m}$ high and 30 $\mathrm{cm}$ diam., bark greyish-brown and scaling, slash exuding white latex, buttresses inconspicuous; tree flowering and fruiting on the trunk from ground level to crown; wet lowland forest and savanna forest, often along riverbanks.

Distribution. Brazil (Amapá, Amazonas, Pará), Fr. Guiana, Suriname.

\section{Chrysophyllum manaosense} (Aubréville) Pennington PI. 5, fig. 1

Leaves with $16-32$ pairs of secondary veins. Fascicles on branches and on trunk from ground level to crown, 5-15-flowered; pedicels 0.4-1 $\mathrm{cm}$, in fruit to $2(-4) \mathrm{cm}$ long; fruiting calyx (4-)5-merous, 0.2-0.5 cm long, 


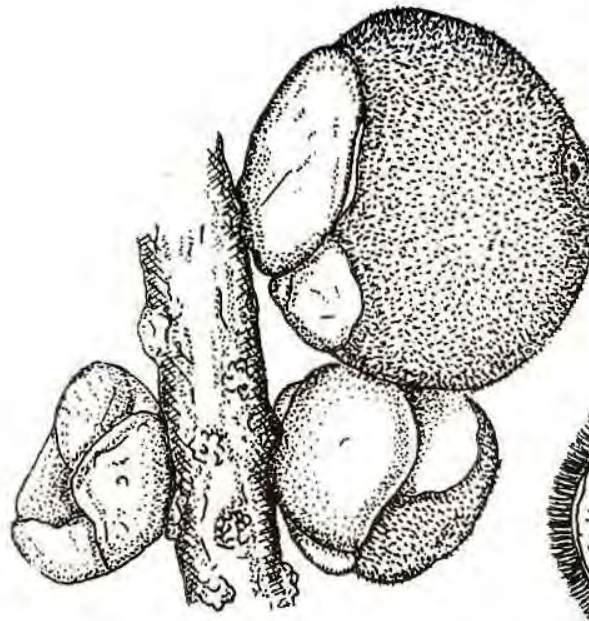

1a

Ic

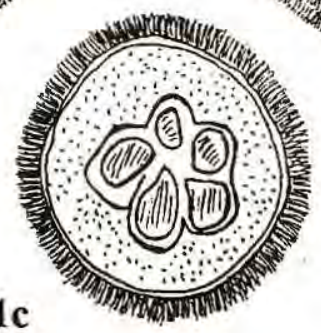

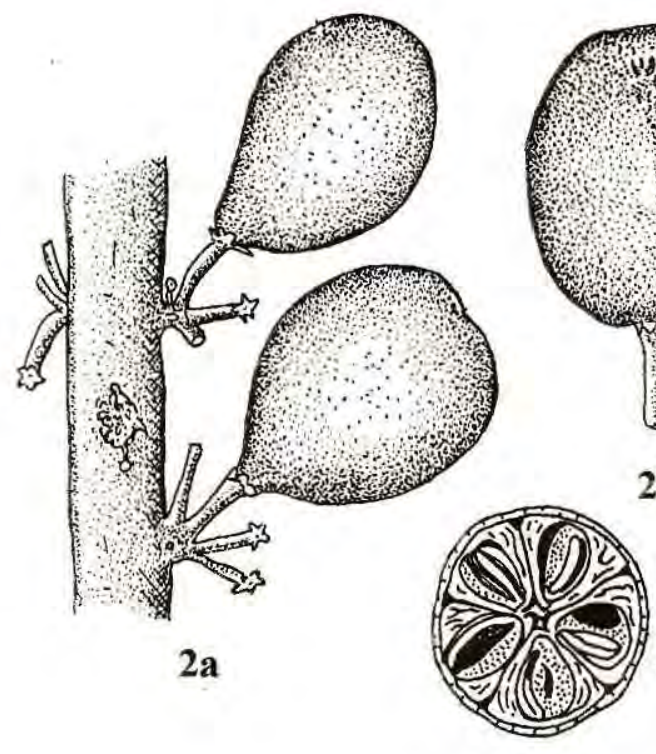

3b

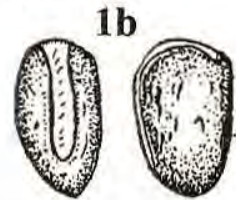

Id

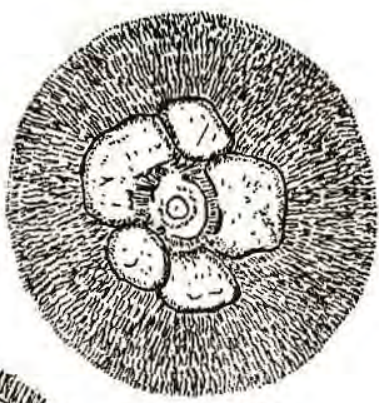

b 
corolla lobes 5 , persistent in fruit, 0.2 $0.3 \mathrm{~cm}$ long. Fruit ellipsoid or broadly obovoid, $2.5-4.2 \times 2.5-3.5 \mathrm{~cm}$, apex rounded to truncate, apiculate, base obtuse, smooth, golden-brown velutinous, maturing yellow to orange; seeds 2-5, 2.2-2.6 x 1.0-1.5 cm, laterally compressed, apex rounded, base acute, testa rough, adherent to the pulp, dull brown, scar adaxial and basal, extending most of the length of the seed, $0.1-0.15 \mathrm{~cm}$ wide.

Notes. Tree to $25 \mathrm{~m}$ high and 45 $\mathrm{cm}$ diam., sometimes with buttresses, bark reddish, shallowly fissured, latex white; mature pulp seen eaten by golden-faced sakis (Pithecia pithecia chrysocephala) north of Manaus, dropping the seeds intact (Setz, 1993), and by red-cap moustached tamarins (Saguinus mystax pileatus) in the $\mathrm{R}$. Urucú region, Amazonas, Brazil, swallowing the seeds and pulp and dispersing the seeds endochorically (Peres, 1993); mixed wallaba (Eperua falcata) forest and terra-firme forest on white sand or clay.

Distribution. Brazil (Amazonas, Pará), Am. Colombia and Peru, Suriname.

\section{Chrysophyllum prieurii $\mathrm{A}$. de Candolle}

abiurana, abiú, mocambo, castanha-vermelha, massaranduba (B); pepre-bortri, kwatabobi (S); malobi, pepeboiti (P) PI. 5, fig. 2

Leaves with 7-14 pairs of secondary veins, rufous-brown sericeous below. Fascicles ramiflorous, 5-15flowered; sepals 5, persistent in fruit, $0.2 \mathrm{~cm}$ long; pedicels $0.5-1 \mathrm{~cm}$, in fruit to $3 \mathrm{~cm}$ long, firm, brown. Fruit subglobose, broadly ellipsoid or oblong-ellipsoid, usually rounded at apex and base, to $4.5 \times 5-6 \mathrm{~cm}$, maturing yellow to orange, epicarp hard, almost smooth and puberulous to glabrous, to verrucose or echinate-muricate, pulp white or yellowish, sweet-tasting; seeds $1-5$, ellipsoid, slightly to strongly laterally compressed, 2.3-2.7 x 1.6-1.8 x $1.1 \mathrm{~cm}$, testa brownish, dull, smooth, adherent to the pulp; scar narrow, extending most of the length of the seed, $2-2.3 \times 0.15-0.4 \mathrm{~cm}$.

Notes. Tree to $40 \mathrm{~m}$ high and $120 \mathrm{~cm}$ diam., with a cylindrical bole and steep branched, to $2 \mathrm{~m}$ high buttresses; bark reddish brown, finely vertically cracked or shallowly fissured, scaling; slash pink or cream, exuding little yellow or white latex; in Suriname, golden-handed tamarins (Saguinus midas midas) fed on the mature pulp, dropping the seeds intact; in Brazil ( $R$. Urucú region), Geoffroy's woolly monkeys (Lagothrix lagotricha cana) and tufted capuchin monkeys (Cebus apella) were seen feeding on the mature pulp, swallowing and dispersing the seeds endochorically (Peres, 1994), and Pionites parrots feeding on ripe fruits (Peres, pers comm.); north of Manaus, golden-faced sakis (Pithecia pithecia chrysocephala) were seen predating on the immature seeds (Setz, 1993), and black spider monkeys (Ateles paniscus) and Guianan brown capuchins (Cebus apella apella) feeding on mature pulp, dispersing the seeds endochorically; in Colombia ( $\mathrm{R}$. Apaporis), Humboldt's woolly monkeys (Lagothrix l. lagotricha) fed on 
the immature green, and ripe orange fruits (Defler, pers. comm.); terrafirme rainforest on clay or sand, also found in savanna forest on white sand.

Distribution. Brazil (Amapá, Amazonas, Pará), Colombia, Guianas, Peru, Venezuela.

Chrysophyllum section 5. Aneuchrysophyllum Engler

Leaves spaced or clustered at the shoot apex, spirally arranged. Fascicles axillary or on the smaller branches; flowers bisexual or unisexual, sepals not accrescent in fruit. Fruit with strongly laterally compressed seeds with a narrow adaxial scar, and a smooth, shining testa, not adherent to the pulp.

\section{Chrysophyllum durifructum} (Rodrigues) Pennington Pl. 5, fig. 3

Leaves with 12-16 pairs of secondary veins. Fascicles axillary or below the leaves, few-flowered; pedicels $0.5-1 \mathrm{~cm}$ long, in fruit stout, $0.7 \times 1.3$ $\mathrm{cm}$, somewhat sunken in base of fruit. Fruit subglobose, $5-6.5 \times 5.2 \mathrm{~cm}$, green, epicarp hard, somewhat rough, glabrous; seeds up to 5 , often 2 or 3 abortive, $3.3-4.3 \times 1.5-1.7 \times 0.9 \mathrm{~cm}$, with an abaxial keel at base and apex, lightbrown glossy, scar 2.3-3.3 x 0.3$0.6 \mathrm{~cm}$, dull.

Notes. Tree to $28 \mathrm{~m}$ high and 50 $\mathrm{cm}$ diam., trunk cylindrical, bark thick, scaling, slash exuding scant white latex; north of Manaus, black bearded sakis (Chiropotes satanas chiropotes) were seen predating on the immature seeds (Frazão, 1992), whereas in the R. Urucú region, Geoffroy's woolly monkeys (Lagothrix lagotricha cana) were seen feeding on the ripe pulp, swallowing the seeds and dispersing them endochorically (Peres, 1994.); terra- firme rainforest.

Distribution. Brazil (Central Amazonas).

Chrysophyllum eximium Ducke

cuquirana, guajara-rana, massaranduba-rana (B) Pl. 6, fig. 1

Leaves with 7-12 pairs of secondary veins, with a dense persistent golden or ferrugineous indumentum below. Fascicles ramiflorous, born just below the leaves, 5-10-flowered; pedicels $0.1-0.5 \mathrm{~cm}$, in fruit $0.2-0.5 \mathrm{~cm}$ long; sepals 5, persistent in fruit. Fruit ovoid or subglobose, $4.5-7 \times 5-6 \mathrm{~cm}$, apex slightly depressed or obtusely acuminate over $1 \mathrm{~cm}$, base truncate, the pedicel somewhat sunken, green to yellow, eventually brown, epicarp hard, $1.3-1.5 \mathrm{~cm}$ thick, smooth, glabrous; seeds 2-5, to $3.5 \times 1.3 \times 1.0 \mathrm{~cm}$.

Notes. Tree to $20 \mathrm{~m}$ high and 35 $\mathrm{cm}$ diam., slash exuding white latex; in French Guiana (Arouany River), red-faced black spider monkeys (Ateles paniscus) were seen feeding on the ripe fruits and exclusively dispersing the large seeds, in Suriname, both Guianan brown capuchins (Cebus apella apella) and red-faced black spider monkeys (Ateles paniscus) were seen feeding on the mature pulp, the spider monkeys being locally the only and exclusive dispersal agents for this species, whereas black bearded sakis (Chiropotes satanas chiropotes) predated on the immature seeds over more than a 4-month period (Van Roosmalen, 1981, 1985, 1988); lowland rainforest, sometimes on periodi- 


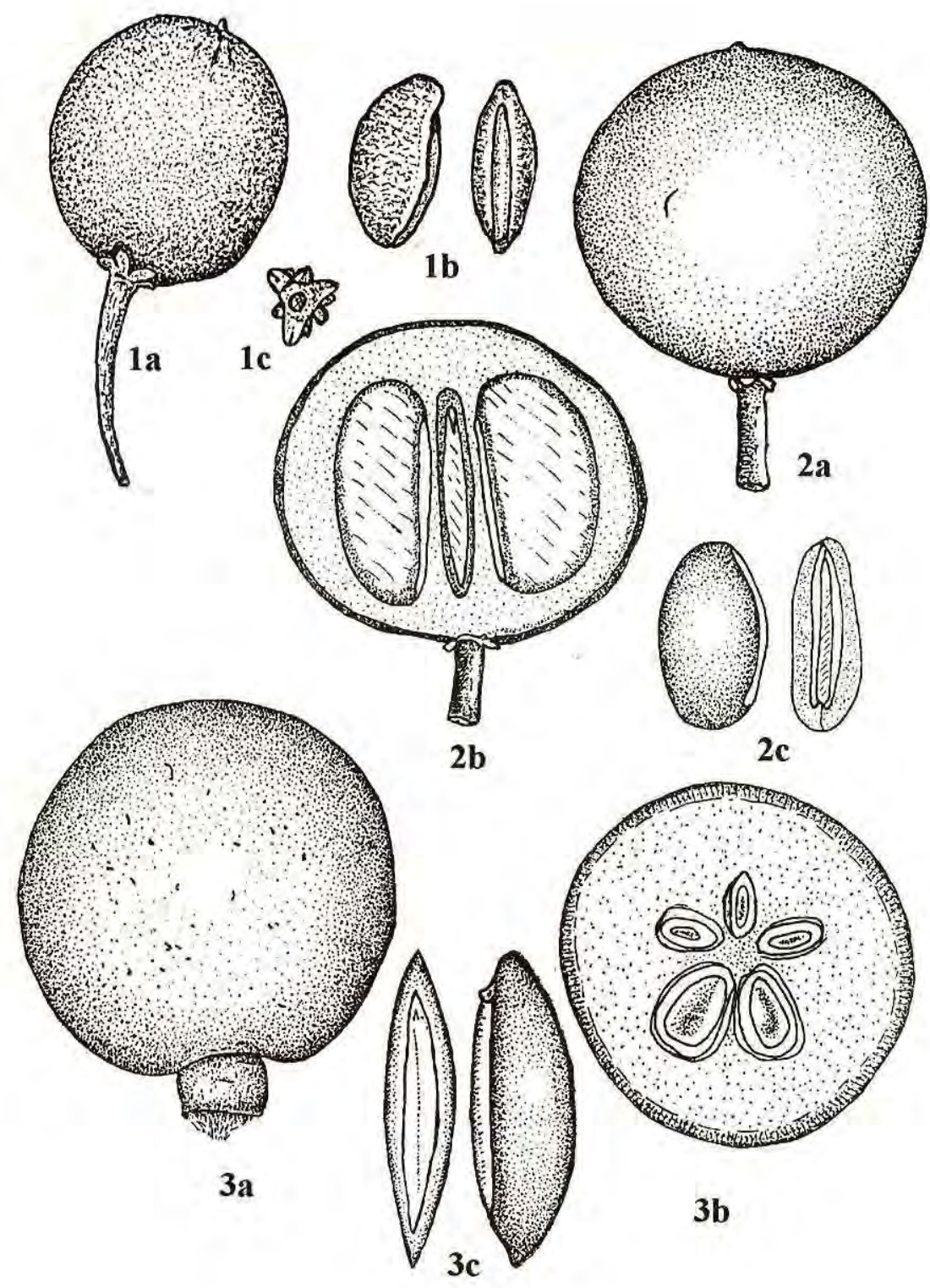

PI. 5. Figs. 1-3, SAPOTACEAE. 1. Chrysophyllum manaosense, a. fruit; b, seed; c. fruiting calyx from below (Setz 204, 206; Peres 805, 643). 2. C. prieurii, a. fruit; b. fruit, longitudinal section showing three seeds; seed, lateral and frontal view (Van Roosmalen 21). 3.C. durifructum, a. fruit; b. cross section of fruit; c. seed, frontal and lateral view (Frazão 250, 341; Peres 618). 
cally flooded land.

Distribution. Brazil (Amapá, Amazonas), Suriname.

\section{Chrysophyllum lucentifolium subsp. \\ pachycarpum Pires \& Pennington}

abiú-branco, guajara (B) PI. 6, fig. 2

Leaves with (8-)13-20 pairs of secondary veins. Fascicles axillary and ramiflorous below the leaves, 2-10flowered; pedicels $0.2-0.6 \mathrm{~cm}$ long. Fruit ovoid, subglobose or obovoid, $3.5-5 \mathrm{~cm}$ long, apex acute to rounded or truncate, base rounded or truncate, yellow, epicarp thick, smooth or irregularly and coarsely tuberculate, glabrous; seeds several, 1.4-2.5 cm long, scar extending most of the length of the seed and sometimes along the base, $0.15-0.3 \mathrm{~cm}$ wide.

Notes. Tree to $40 \mathrm{~m}$ high and 80 $\mathrm{cm}$ diam., bole cylindrical, when old with small buttresses, slash cream, exuding little white latex; lowland rainforest.

Distribution. Brazil (Amazonas, Pará, Rondônia, Roraima), Bolivia, Colombia, Ecuador, Peru, Venezuela.

\section{Chrysophyllum pomiferum (Eyma)}

\section{Pennington}

abiurana (B); limonaballi, paripiballi (A); laurierkers (SD); kimboto (S); boesisoke, monkisoki (P) Pl. 6, fig. 3

Leaves with 7-10 pairs of secondary veins. Fascicles axillary and ramiflorous, below the leaves, 3-10flowered, flowers unisexual; fruiting sepals 5 , broadly ovate, $0.2-0.3 \mathrm{~cm}$ long; pedicels $0.1-0.2 \mathrm{~cm}$, in fruit 0.3 $\mathrm{cm}$ long and $0.4 \mathrm{~cm}$ thick, fruits solitary or in pairs. Fruit obovoid when young, (sub)globose when mature, 2.3-4.0 x 2.0-3.5 cm, apex and base rounded, yellow, apiculate, often with a brown circular patch at the apex ca. $0.4 \mathrm{~cm}$ diam., epicarp thin leathery, smooth, glabrous, pulp fleshy, firm, sweet-tasting; seeds to $5,1.3-1.5 \times 0.8$ $x 0.7 \mathrm{~cm}$, scar extending most of the length of the seed, $0.1 \mathrm{~cm}$ wide.

Notes. Tree to $45 \mathrm{~m}$ high and 90 $\mathrm{cm}$ diam., sometimes with to $1.5 \mathrm{~m}$ high buttresses, that extend out to 3(10) $\mathrm{m}$, bark greyish to redbrown, fissured or scaling, slash light orange, exuding white latex; in Am. Colombia (R. Apaporis), Humboldt's woolly monkeys (Lagothrix lagotricha lagotricha) were seen feeding on the ripe fruits, dispersing the seeds via the gut, while depleting a particular tree with a huge crop over 3 or more days (which is unusual for woolly monkeys)(Defler, pers. comm.), in W Brazil (Pico da Neblina National Park), Humboldt's black-headed uacaries (Cacajao m. melanocephalus) were seen feeding on the mature pulp, dropping the seeds (Boubli, 1997), and north of Manaus, golden-faced saki monkeys (Pithecia pithecia chrysocephala)(Setz, 1993) and black bearded sakis (Chiropotes satanas chiropotes)(Frazão, 1992) predated on the immature seeds, whereas in Suriname (Voltzberg/Raleighvallen Nature Reserve), black bearded sakis (Chiropotes satanas chiropotes) were seen feeding both on the immature seeds and the mature pulp (Van Roosmalen et al., 1988), and red howling monkeys (Alouatta s. seniculus) and red-faced black spider monkeys 


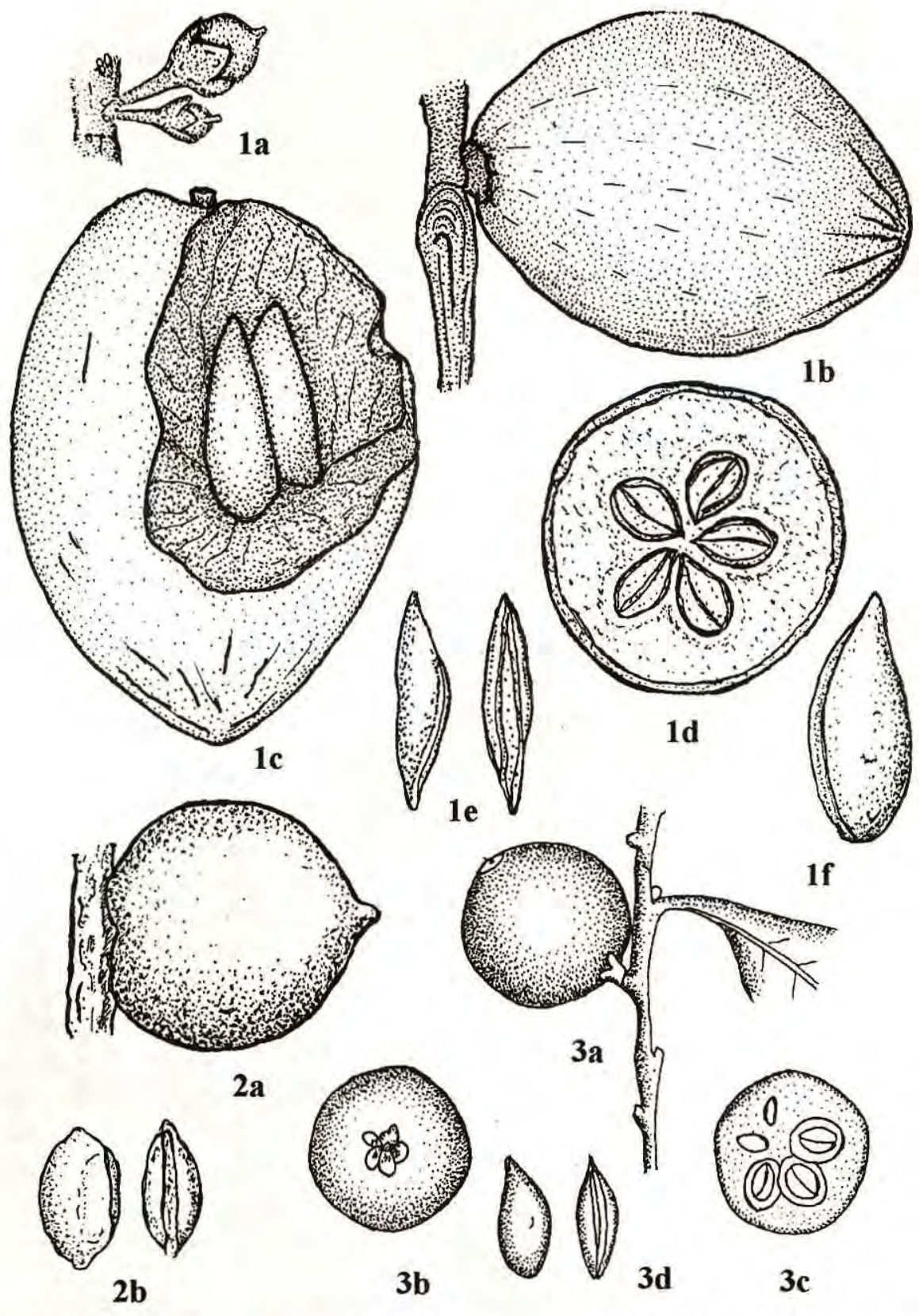

PI. 6. Figs. 1-3. SAPOTACEAE. 1. Chrysophyllum eximium, a. young fruits; b. mature fruit; c. fruit partly opened by monkeys showing two seeds; d. cross section of fruit; e. seed, lateal and frontal view; f. larger seed, lateral view (Van Roosmalen 3359). 2. C. lucentifolium subsp. pachycarpum, a. fruit; b. seed, lateral and frontal view (Liesner \& González 11125; Williams 12911). 3. C. pomiferum, a. fruit; b. fruit from below; c. cross section of fruit; d. seed, lateral and frontal view (Frazão 250; Defler 94, 100, 273; Peres 789). 
(Ateles paniscus) frequently consumed the ripe fruits, during November and December, dispersing endochorically large quantities of seeds; lowland rain and savanna forest over clay or sand, along creeks, on forested slopes and in mountain savanna forest on granite.

Distribution. Brazil (Amazonas, Pará, Roraima), Colombia, Guianas, Peru, Venezuela.

\section{Chrysophyllum venezuelanense}

(Pierre) Pennington

guajara, sorva-do-Peru (B); zolive (FrG) Pl. 7, fig. 1

Leaves with 8-12(-16) pairs of secondary veins. Fascicles axillary and in the axils of fallen leaves, 3-10-flowered, flowers unisexual; sepals $5,0.2$ $0.4 \mathrm{~cm}$ long; pedicels $0.2-0.7 \mathrm{~cm}$ long. Fruit ovoid or globose, 4.5-5.5 x 4.5-5.5 $\mathrm{cm}$, apex rounded, base truncate or depressed, greyish or pale brown when dry, smooth, covered with innumerous scalelike small lenticels, glabrous; seeds to 5 , 2.5-3 cm long, scar extending the length of the seed, $0.2-0.4 \mathrm{~cm}$ wide.

Notes. Tree to $40 \mathrm{~m}$ high and 50 $\mathrm{cm}$ diam., already flowering and fruiting when 3-4 $\mathrm{m}$ high, sometimes with small buttresses; wet lowland rainforest, also in more seasonal forest types and in montane rainforest and cloud forest.

Distribution. Brazil (introduced and possibly naturalized), Colombia, Ecuador, French Guiana, Peru, N Venezuela.

\section{Diploön Cronquist}

Leaves spaced, alternate and distichous, or weakly spirally arranged. Inflorescences fasciculate, axillary and below the leaves; ovary 1-locular.
Fruit a berry; seeds 1, with a small broad basal or basi-ventral scar.

Notes. Trees; one species in South America.

\section{Diploön cuspidatum (Hoehne) Cronquist \\ batinga-roxa, abiurana-seca (B) \\ Pl. 7, fig. 2}

Leaves with 17-20 pairs of secondary veins. Fascicles 3-10-flowered; flowers bisexual, sepals 4-5; pedicels 0.4- $0.5 \mathrm{~cm}$ long. Fruit broadly ellipsoid or globose, $1.8-2 \mathrm{~cm}$ long, apex and base rounded, maturing reddish to black, epicarp tough, smooth, glabrous, pulp thin, fibrous-fleshy, adherent to the seed; seed broadly ellipsoid, ca. $1.5 \mathrm{~cm}$ long, rounded at apex and base, testa smooth, shining, scar cordate, ca. $0.7 \times 0.5 \mathrm{~cm}$, rough.

Notes. Tree to $30 \mathrm{~m}$ high and 50 $\mathrm{cm}$ diam., with a slightly fluted bole and buttresses, bark reddish-brown, scaling, slash exuding white latex; mature pulp together with seed swallowed by monkeys and birds (Hoehne, 1933); lowland terra-firme rainforest.

Distribution. Brazil (Amazonas, Pará, Rondônia), Guyana (component of Ocotea rodiaei dominated rainforest), Am. Peru, Venezuela.

\section{Ecclinusa Martius}

Leaves spirally arranged, usually loosely clustered at the shoot apex. Inflorescences axillary or in the axils of fallen leaves; flowers sessile, usually unisexual; sepals (4-)5. Fruit a thin-walled berry, often constricted between the seeds; seeds 1 to several, globose or ellipsoid, sometimes slightly laterally compressed or shaped 
like the segment of an orange, testa smooth, shining, and thin, scar adaxial and nearly always extending around the base of the seed, usually narrow.

Notes. Trees, rarely shrubs, with 11 species in the Neotropics.

\section{Ecclinusa bullata Pennington} coquirana-de-pelo (B) Pl. 7, fig. 3

Leaves with 20-26 pairs of secondary veins, coriaceous, strongly bullate, densely pubescent below mixed with erect two-branched hairs. Fascicles ramiflorous, 5-15-flowered; flowers unisexual, sepals 5, persistent in fruit; fruits sessile. Fruit depressed globose, $2.2 \times 4 \mathrm{~cm}$ to globose, $5-6 \mathrm{~cm}$ in diam., apex rounded and sunken, base truncate or sunken, maturing tawny-orange, epicarp thick, smooth, golden-brown and densely longvelutinous; seeds to 5 , laterally compressed, to $2.3-2.4 \times 1.2 \times 1.0 \mathrm{~cm}$, light brown, rounded at apex and base, scar extending around the base of the seed, $0.3-0.5 \mathrm{~cm}$ wide, widening toward base.

Notes. Tree to $25 \mathrm{~m}$ high and 50 $\mathrm{cm}$ diam., without buttresses, bole cylindrical, bark rather smooth, brown, slash soft, exuding abundant white latex; in the R. Urucú region, Geoffroy's woolly monkeys (Lagothrix lagotricha cana) were seen feeding on the ripe pulp, dispersing the seeds endochorically (Peres, 1994), whereas, in Pico da Neblina National Park, Humboldt's black-headed uacaries (Cacajao m. melanocephalus) predated on the immature seeds (Boubli, 1997); high terra-firme rainforest.

Distribution. Brazil (W. Amazonas), Venezuela (Amazonas).
Ecclinusa dumetorum (Baehni)

Pennington Pl. 7, fig. 4

Leaves coriaceous, with 6-9 pairs of secondary veins. Fascicles 25-flowered, axillary and ramiflorous; flowers bisexual, sepals 5. Fruit ellipsoid, ca. $1.7 \mathrm{~cm}$ long, apex and base rounded, epicarp yellow, thin, smooth, subglabrous, pulp fleshy; seeds 1 , ellipsoid, slightly laterally compressed, ca. $1.3 \mathrm{~cm}$ long, rounded at apex and base, scar extending around the base of the seed, ca. $0.2 \mathrm{~cm}$ wide.

Notes. Shrub to $3 \mathrm{~m}$ high; sandstone savannas on table mountains (tepuis).

Distribution. C Suriname (only found on Tafelberg).

Ecclinusa guianensis Eyma

bartaballi (A); batambali (S,P); abiurana-abiú/bacuri/cajú, bacurí, caucherama (B) Pl. 7, fig. 5

Leaves coriaceous, glabrous, with (12-)14-30 pairs of secondary veins. Fascicles mostly axillary, 4-6flowered; flowers unisexual, sepals 5; fruits sessile. Fruit subglobose, 2.7-2.9 x $2.1-2.4 \mathrm{~cm}$, sometimes to $3.5 \mathrm{~cm}$ diam., apex and base truncate or rounded, epicarp yellow to brownishorange, thin, contracting between the seeds on drying, smooth, brown- or grey-puberulous, pulp fleshy; seeds (1)2-4(-5), narrowly ellipsoid, 1.1-1.8 $\mathrm{cm}$ long to ca. $2.6 \times 1.3 \times 1.1 \mathrm{~cm}$, rounded at apex and base, sometimes slightly laterally compressed, scar extending around the base of the seed, $0.2-0.3 \mathrm{~cm}$ wide in several-seeded fruits, up to $0.9 \mathrm{~cm}$ wide in singleseeded fruits. 
Notes. Tree to $30 \mathrm{~m}$ high and 50 $\mathrm{cm}$ diam., bole cylindrical, bark reddish-brown to dull grey-brown, smooth or scaling in small rectangular pieces, slash pale brown, exuding copious white latex; in the R. Urucú region, Amazonas, Brazil, ripe fruits were frequently eaten by buffy sakis (Pithecia albicans), tufted brown capuchin monkeys (Cebus apella), Geoffroy's woolly monkeys (Lagothrix lagotricha cana), red-cap moustached tamarins (Saguinus mystax pileatus) and Avila-Pires saddle-back tamarins (Saguinus fuscicollis avilapiresi) (Peres, 1991, 1993, 1994), in terra firme forest north of Manaus, black bearded sakis (Chiropotes satanas chiropotes) (Frazão, 1992) and golden-faced sakis (Pithecia pithecia chrysocephala) (Setz, 1993) were seen predating on the immature seeds, in Suriname (Voltzberg/Raleighvallen Nature Reserve) this species was a preferred fruit for 6 of the 8 primates, the ripe pulp being eaten by golden-handed tamarins (Saguinus midas midas), Guianan brown capuchin monkeys (Cebus apella apella), white-faced sakis (Pithecia pithecia pithecia), red howling monkeys (Alouatta seniculus seniculus) and red-faced black spider monkeys (Ateles paniscus), the immature seeds being heavily predated upon by black bearded sakis (Chiropotes satanas chiropotes) and parrots (Van Roosmalen, 1981, 1985, 1988); the seeds of this species are endochorically dispersed by spider, woolly, howling, tufted and brown capuchin monkeys, and by yellow-footed tortoises
(Geochelone denticulata); high rainforest and riverine forest on nonflooded land, also found in semi-deciduous forest, rocksavannas, savanna forest and mountain savanna forest on bauxite or granite.

Distribution. Brazil (Amazonas, Pará, Roraima), Guianas, Venezuela.

Ecclinusa lanceolata (Martius \&

Eichler) Pierre

coquirana braba do igapó, abiurana (B) PI. 7, fig. 6

Leaves coriaceous, glabrous, with 20-33 pairs of secondary veins. Fascicles axillary and ramiflorous, 510-flowered; flowers unisexual, sepals five, $0.25-0.4 \mathrm{~cm}$ long, circular, persistent in fruit; fruits sessile on wartlike outgrowths. Fruit transversely ellipsoid to globose, $2.5 \times 3.3 \times 2.5 \mathrm{~cm}$ to $3.4-3.8 \times 3-3.2 \mathrm{~cm}$, sometimes up to $5-6 \mathrm{~cm}$ diam., apex rounded or obtuse, apiculate, base truncate, epicarp orange-yellow, thick coriaceous, smooth, minutely puberulous to glabrous, mesocarp rather spongy, pulp white, sweet-tasting; seeds 4-5, broadly ellipsoid or shaped like the segment of an orange, $2.3 \times 1.5 \times 1 \mathrm{~cm}$, sometimes to $3 \mathrm{~cm}$ long, scar extending around the base of the seed, $0.5-0.9 \mathrm{~cm}$ wide.

Notes. Tree to $35 \mathrm{~m}$ high and 50 $\mathrm{cm}$ diam., without buttresses, bole cylindrical, bark dark brown or blackish, strongly dappled, slash cream to orange, exuding copious sticky white latex; in Amazonas, Brazil (R. Urucú region), tufted capuchin monkeys (Cebus apella) were seen feeding on the mature fruits (Peres, pers. comm.), and north of Manaus, black bearded sakis (Chiropotes satanas chiropotes) 

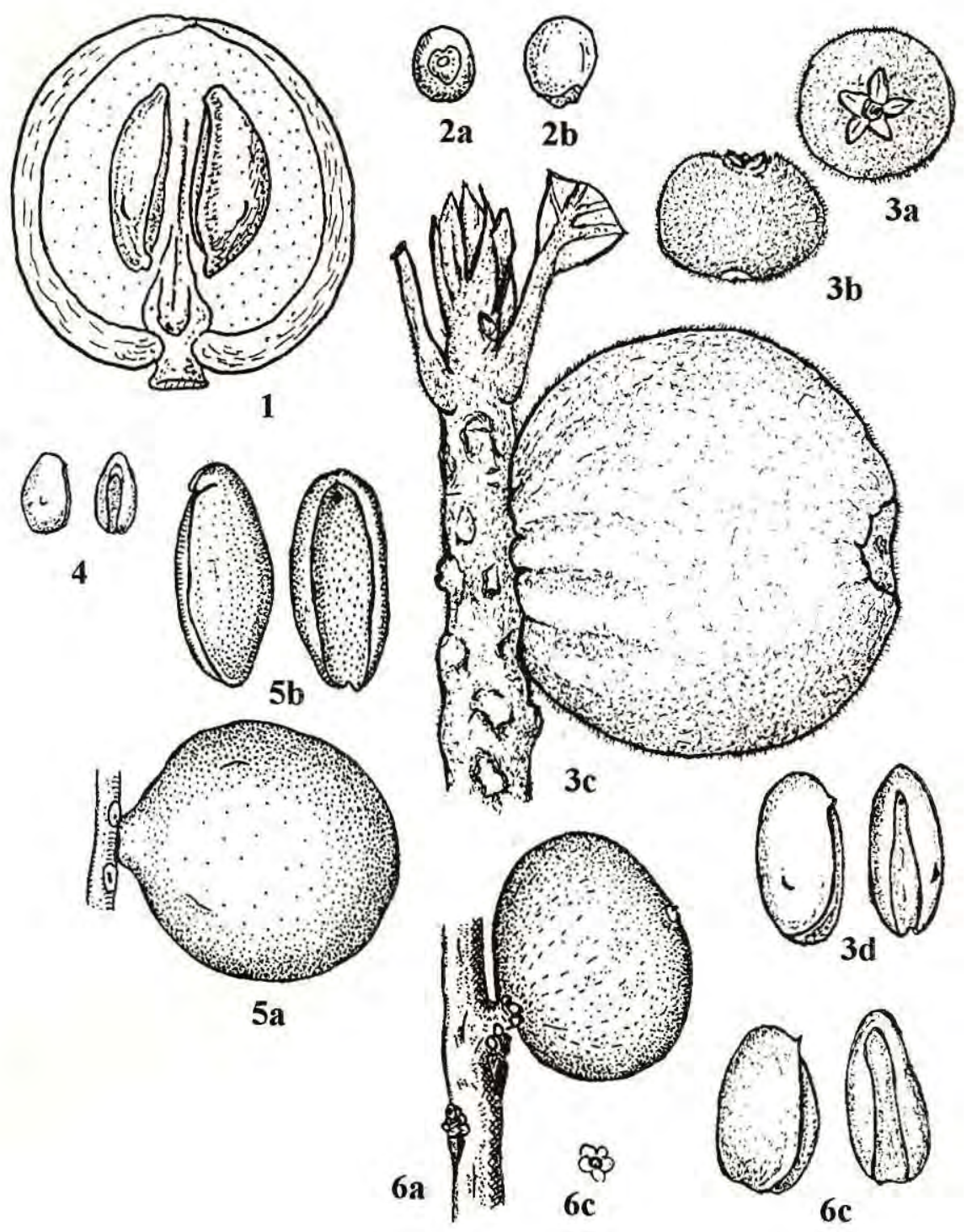

PI. 7. Figs. 1-6. SAPOTACEAE. 1. Chrysophyllum venezuelanense, fruit opened longitudinally showing two seeds (Pennington 10669). 2. Diploön cuspidatum, a. seed from below showing the basal cordate scar; b. seed, lateral view (Hatschbach 19595). 3. Ecclinusa bullata, a. young fruit from below; b. young fruit, lateral view; c. mature fruit; $d$. seed, lateral and frontal view (Boubli 57; Peres 522). 4. E. dumetorum, seed, lateral and frontal view (Maguire 24412). 5. E. guianensis, a. fruit; b. seed from 1-seeded fruit, lateral and frontal view (Van Roosmalen 2453). 6. E. lanceolata, a. fruit; b. fruiting calyx; c. seed, lateral and frontal view (Frazão VII; Peres 434, 466). 
were seen predating on the immature seeds (Frazão, 1992); terra-firme and periodically flooded lowland rainforest.

Distribution. Brazil (Amapá, Amazonas, Rondônia), Colombia, Fr. Guiana, Guyana, Peru, Venezuela.

Ecclinusa lancifolia (Martius \&

Eichler) Eyma Pl. 8, fig. 1

Leaves slender, lanceolate, coriaceous, glabrous, with 25-40 pairs of secondary veins giving a striate appearance as in some Manilkara and Micropholis species. Fascicles 3-4flowered, fruiting sepais $4-5,0.4 \mathrm{~cm}$ long; fruits sessile. Fruit globose or transversely ellipsoid, to $4 \times 5 \times 4 \mathrm{~cm}$, constricted between the seeds when 2or 3-seeded, epicarp greenish, maturing bright orange, thin, irregularly sulcate, appressed puberulous to subglabrous; seeds 1-3, broadly ellipsoid to subglobose, not laterally compressed, 1-1.2 cm long, base and apex rounded, scar extending around the base of the seed, 0.2-0.4 cm wide.

Notes. Shrub or small tree to 6 $\mathrm{m}$, bark with milky latex; in Pico da Neblina National Park, Brazil, along the R. Cauaburi, Humboldt's blackheaded uacaries (Cacajao $\mathrm{m}$. melanocephalus) were seen predating on the immature seeds (Boubli, 1997); permanently black-water flooded forest (igapó).

Distribution. Brazil (C and W Amazonas).

Ecclinusa psilophylla Sandwith barata (A) PI. 8, fig. 2

Leaves coriaceous, glabrous, with 10-14 pairs of secondary veins.
Fascicles 4-6-flowered, ramiflorous on the smaller branches, and cauliflorous; sepals 5. Fruit subglobose, ca. $2 \mathrm{~cm}$ long, apex and base rounded, constricted between the seeds, maturing red, epicarp thin, glabrous, smooth; seeds 1-4, ellipsoid, ca. $1.2 \mathrm{~cm}$ long, apex and base rounded.

Notes. Tree to $15 \mathrm{~m}$ high, slash exuding white latex; white sand savanna forest, sometimes abundant in dry evergreen wallaba (Eperua falcata and $E$. grandiflora dominated) forest.

Distribution. Guyana, Suriname. Ecclinusa ramiflora Martius coquirana-brava (grande)(B); doekali (S) PI. 8, fig. 3

Leaves coriaceous, tomentose or pubescent below, with 16-30 pairs of secondary veins. Fascicles mostly ramiflorous, 5-10-flowered; fruits sessile, solitary on wart-like outgrowths of $1 \mathrm{~cm}$ diam.; flowers unisexual, sepals $4-5$, persistent in fruit, triangular, $0.2-0.3 \times 0.2-0.3 \mathrm{~cm}$. Fruit obovoid or (sub)globose, 2.3-3.3 x $2.2-3.6 \mathrm{~cm}$ to $3.8-4.5 \times 3.4-4.1 \mathrm{~cm}$, sometimes to $5.2 \mathrm{~cm}$ diam., apex rounded or depressed, prickle sunken, base often constricted over up to 0.4 $\mathrm{cm}$, maturing yellow to orange or red, epicarp rather thin coriaceous, tending to contract between the seeds when dried, smooth, densely brown pubescent to velutinous, indumentum easily to remove, pulp tasting after apple; seeds 1-2(-5), ellipsoid, 1.8-2.7 $\times 1.1$ $1.5 \times 0.9-1.2 \mathrm{~cm}$, laterally compressed or shaped like the segment of an orange, blackbrown, shining, scar extending around the base of the seed, 

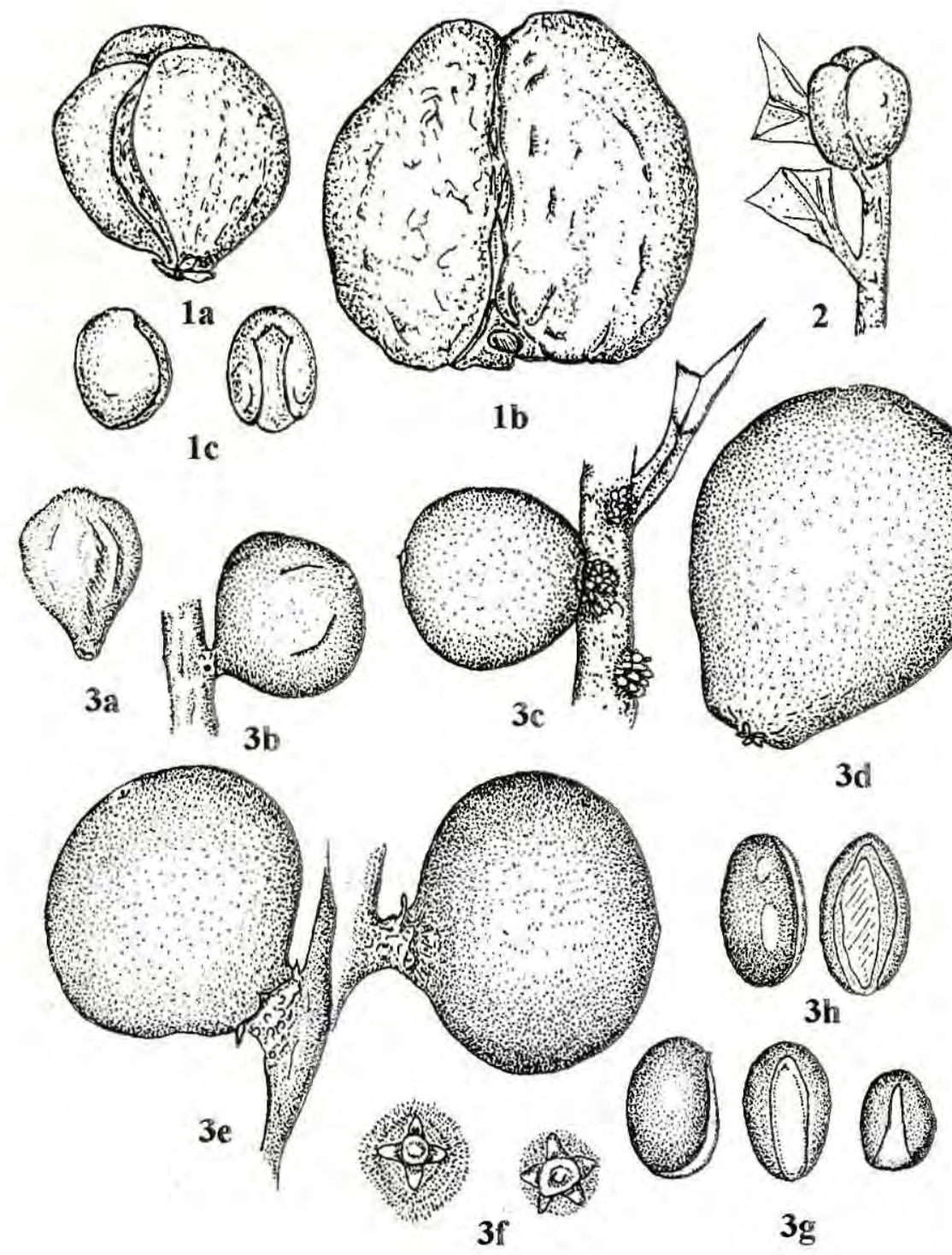

P1. 8. Figs. 1-3. SAPOTACEAE. 1. Ecclinusa lancifolia, a. 3-seeded fruit; b. 2-seeded fruit; c. seed, lateral and frontal view (Boubli 70). 2. E. psilophylla, fruit (Tutin 258). 3. E. ramiflora, a, b , c. young fruit; d, e. fruit; f. 4- and 5-merous fruiting calyx; g. seed, lateral, frontal, and basal view; h. other seed, lateral and frontal view (Van Roosmalen 10, 60, 61, 63). 
0.3-0.6 cm wide, dull; fruits weighing 138 grams ( $n=6)$, seeds 7 grams.

Notes. Tree to $40 \mathrm{~m}$ high and $100 \mathrm{~cm}$ diam., bole cylindrical with low buttresses, bark blackish-grey to reddish-brown, scaling, with conspicuous dapple marks, slash yellow to pinkish-brown exuding abundant white or cream-colored latex; in Brazil, Amazonas, north of Manaus, the immature seeds were eaten by golden-faced sakis

(Pithecia pithecia chrysocephala)(Setz, 1993) and black bearded sakis (Chiropotes satanas chiropotes) (Frazão, 1992), and in the R. Urucú region, Amazonas, Avila Pires saddle-back tamarins (Saguinus fuscicollis avilapiresi) and red-cap moustached tamarins (Saguinus mystax pileatus) together, tufted capuchins (Cebus apella), and Geoffroy's woolly monkeys (Lagothrix lagotricha cana) were seen feeding on the mature pulp (Peres, 1993, 1994), whereas only capuchins and woolly monkeys swallowed and dispersed the seeds of this species; lowland rain forest and seasonal evergreen forest, always on non-flooded land, also in cloud forest (Venezuela).

Distribution. Bolivia, Brazil (Acre, Amazonas, Pará, Rondônia), Colombia, French Guiana, Suriname, Venezuela.

\section{Elaeoluma Baillon}

Leaves spirally arranged. Inflorescences mostly axillary; flowers unisexual; calyx a single whorl of (4 or) 5 imbricate sepals. Fruit a broadly ellipsoid to subglobose, single-seeded berry; seed broadly ellipsoid, not or slightly laterally compressed, testa smooth or slightly wrinkled, shining, scar adaxial, the length of the seed, narrow or broad.

Notes. Trees or shrubs; four species in the Neotropics.

\section{Elaeoluma glabrescens (Martius \&}

Eichler) Aubréville

abiurana, jarai, lombrigueira, pau-de-rato (B) Pl. 9, fig. 1

Leaves with (6-)9-12(-14) pairs of secondary veins. Fascicles 3-25flowered, axillary and below the leaves; sepals 5 , infundibular, 0.25-0.4 $\mathrm{cm}$ long, in fruit $0.5 \mathrm{~cm}$ long; pedicels $0.3-1.2 \mathrm{~cm}$ long. Fruit broadly ellipsoid, to $2.5(-3) \times 2.1 \mathrm{~cm}$, rounded at both ends, apex with stout, to $0.2 \mathrm{~cm}$ long prickle, epicarp green to brown or red, soft, smooth (shrinking when dry), glabrous; seed ellipsoid, 1.3-1.6 $\mathrm{x} 1.1 \mathrm{~cm}$, plano-convex, light brown, with an irregular projecting fringe around the edge of the scar, scar 0.8$1.1 \mathrm{~cm}$ wide, verrucose.

Notes. Tree to $25 \mathrm{~m}$, sometimes to $38 \mathrm{~m}$ high and $60 \mathrm{~cm}$ diam., slash exuding copious sticky white latex; entire fruits were found in the stomachs of 'tambaqui' fishes (Colossoma macropomum) collected in the várzea of the R. Solimões; found along riversides and in periodically or permanently flooded forests (igapó, várzea), occasionally in white sand savannas.

Distribution. Brazil (Amazonas, Pará), Colombia, Peru, Venezuela (Amazonas).

Elaeoluma nuda (Baehni)

Aubréville PI. 9, fig. 2

Leaves coriaceous, with 7-12 pairs of secondary veins. Fascicles 37-flowered, axillary and below the leaves; sepals (4 or) 5; pedicels 0.4-1.2 
$\mathrm{cm}$ long. Fruit obovoid or broadly ellipsoid, 1.8-2.5 cm long, apex rounded with prickle, base rounded or broadly tapered, epicarp ripening bluish or purple, smooth, glabrous; seed 1.4-1.8 $\mathrm{cm}$ long, slightly laterally compressed, with obtuse apex and base, testa smooth or slightly wrinkled, scar about $3 / 4$ the length of the seed, $0.1-0.3 \mathrm{~cm}$ wide.

Notes. Tree to $25 \mathrm{~m}$ high and 30 $\mathrm{cm}$ diam., sometimes a small tree, slash exuding copious white latex; montane and dwarf forest on sandstone, at altitudes of 1,000-2,300 m.

Distribution. Brazil (NW Amazonas), Suriname (Tafelberg), Venezuela (Bolivar, Amazonas).

\section{Elaeoluma schomburgkiana}

(Miquel) Baillon Pl. 9, fig. 3

Leaves with 5-7(-9) pairs of secondary veins. Fascicles mostly axillary, 1-10-flowered; sepals 5, 0.2-0.3 cm long; pedicels $0.1-0.5 \mathrm{~cm}$ long. Fruit broadly ellipsoid, 1.2-1.4 x 1-1.2 $\mathrm{cm}$, apex rounded, with prickle, base rounded to slightly tapered, epicarp thin, ripening purple or black, smooth, glabrous; seed broadly ellipsoid, $0.9 \mathrm{x}$ $0.7 \mathrm{~cm}$, rounded at both ends, sometimes with a small beak at the apex of the scar, testa brown, scar $0.9 \times 0.5$ $\mathrm{cm}$, dull, rugose or verrucose.

Notes. Many-branched shrub or crooked tree to $10 \mathrm{~m}$ high and $30 \mathrm{~cm}$ diam., slash exuding copious white latex; in wet savannas, flooded forest (igapó) and on sandy beaches.

Distribution. $\mathrm{N}$ and $\mathrm{C}$ Brazil (Amazonas, Roraima), Guyana, S Venezuela.

\section{Manilkara Adanson}

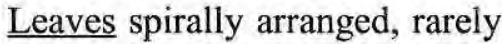

opposite or whorled, often densely clustered at the apex of the stem. Inflorescences axillary or in the axils of leaf scars; flowers solitary or fasciculate, bisexual, calyx consisting of two whorls of (2-)3(-4) free or slightly united sepals, the outer whorl valvate or slightly imbricate. Fruit with one to several seeds, smooth or scaly, glabrous, with fleshy pulp; seeds ellipsoid to obovoid, strongly laterally compressed, testa hard, woody, shining, scar narrowly elongate, basi-ventral or extending along most of the adaxial surface.

Notes. Pantropical genus with 30 species in the Neotropics, mainly trees, rarely shrubs, the shoot apex often covered with a transparent varnish-like wax.

Manilkara bidentata (A. de Candolle) Chevalier subsp. bidentata balata (B,S); boeroewe (S) PI. 9 , fig. 4

Leaves with (10-)12-25 pairs of secondary veins; stipules present, leaving an obvious scar. Fascicles with (2) 5-20 flowers; sepals 0.4-0.6 cm long; pedicels $0.9-2.5 \mathrm{~cm}$ long, usually subtended by small bracts. Fruit ellipsoid or globose, 1-3(-4) cm long, apex and base rounded or truncate, maturing yellow to reddish-orange, smooth, glabrous; seeds $1-2,0.9-2.6 \mathrm{~cm}$ long, often narrow, with an abaxial crest, testa brown, smooth, scar narrow, basi-ventral or adaxial, $0.4-1.2 \mathrm{x}$ $0.1-0.2(-0.4) \mathrm{cm}$.

Notes. Tree to $40 \mathrm{~m}$ high and $130 \mathrm{~cm}$ diam., bole straight cylindrical, with buttresses, bark deeply fissured, greyish- or reddish-brown, slash deep red with copious white latex, the dark red heartwood is extremely hard and heavy; lowland savanna and high 
terra-firme rainforest.

Distribution. Brazil (Pará, Roraima), W Colombia, Guianas, Am. Peru.

Manilkara bidentata (A. de Candolle) Chevalier subsp. surinamensis (Miquel)

Pennington

balata, burue (A); bortri, boletri (S); boiti (P); caramuxy, maparajuba, massaranduba, pendaria (da serra) (B); chicle (V,C) Pl. 9, fig. 5

Leaves with (10-)12-25 pairs of secondary veins; stipules absent. Fascicles with (2-)5-20 flowers; sepals $0.15-0.6 \mathrm{~cm}$ long; pedicels $0.9-2.5 \mathrm{~cm}$ long, usually without small subtending bracts, in fruit to $3.7 \mathrm{~cm}$ long and thickened towards fruit. Fruit ellipsoid or (depressed-)globose, 1-3(-4) cm long, often 1.9-2.2 x 1.6-1.8 cm, apex and base rounded or truncate, with stout prickle, maturing orange or reddish purple to black, smooth, wet weight from two different trees 85.5 grams $(\mathrm{n}=30)$ and 90 grams $(\mathrm{n}=28)$; seeds 1(2), 0.9-2.6 cm long, often 1.2-1.6 x 0.6$0.9 \times 0.3-0.5 \mathrm{~cm}$, narrow, with an abaxial crest, testa brown, smooth, scar narrow, basi-ventral or adaxial, 0.4-1.2 $x$ 0.1-0.2(-0.4) cm.

Notes. Shrub to $2 \mathrm{~m}$ high or small tree in savanna forest, or, in high forest, large tree to over $45 \mathrm{~m}$ high and $65 \mathrm{~cm}$ diam., often with to $1 \mathrm{~m}$ high and wide buttresses, bark deeply fissured, greyish-brown, slash pink or reddish, exuding copious white sticky latex; almost mature greenish-brown fruits were seen eaten by Humboldt's woolly monkeys (Lagothrix $l$. lagotricha), in E Colombia (lower R. Apaporis), swallowing and dispersing the seeds (Defler, pers. comm.), whereas Peres (pers. comm.) saw the following monkeys feeding on the mature fruits in the R. Urucú and R. Juruá (Lago Curapé, west bank) region, Amazonas, Brazil: squirrel monkeys (Saimiri sciureus macrodon), brown capuchin monkeys (Cebus apella), white-faced capuchin monkeys (Cebus albifrons unicolor), Novaes' baldheaded uacaries (Cacajao calvus novaesi), white or buffy sakis (Pithecia albicans), Geoffroy's monk sakis (Pithecia m. monachus), blackfaced black spider monkeys (Ateles chamek), Poeppig's woolly monkeys (Lagothrix lagotricha poeppigii), Geoffroy's woolly monkeys (Lagothrix lagotricha cana), and red howling monkeys (Alouatta seniculus), the larger monkeys swallowing the seeds and dispersing them; in the terra firme forests north of Manaus, golden-faced sakis (Pithecia pithecia chrysocephala) were observed to predate upon the immature seeds (Setz, 1993); fruit crops size in the R. Urucú region was estimated over 9,000 per tree (Peres, pers. comm.); found in periodically flooded lowland forest (igapó and várzea), non-flooded forest and dry savanna forest on white sand; tree sheds its leaves for a short period prior to flowering, the new leaves and flowers developing together.

Distribution. Brazil (Amapá, Amazonas, Pará, Roraima), Am. Colombia, Guianas, Am. Peru, S Venezuela.

Manilkara cavalcantei Pires \& Rodrigues ex Pennington mapajaruba, massarandubajacaré-folha-miuda), pendaria (B) 

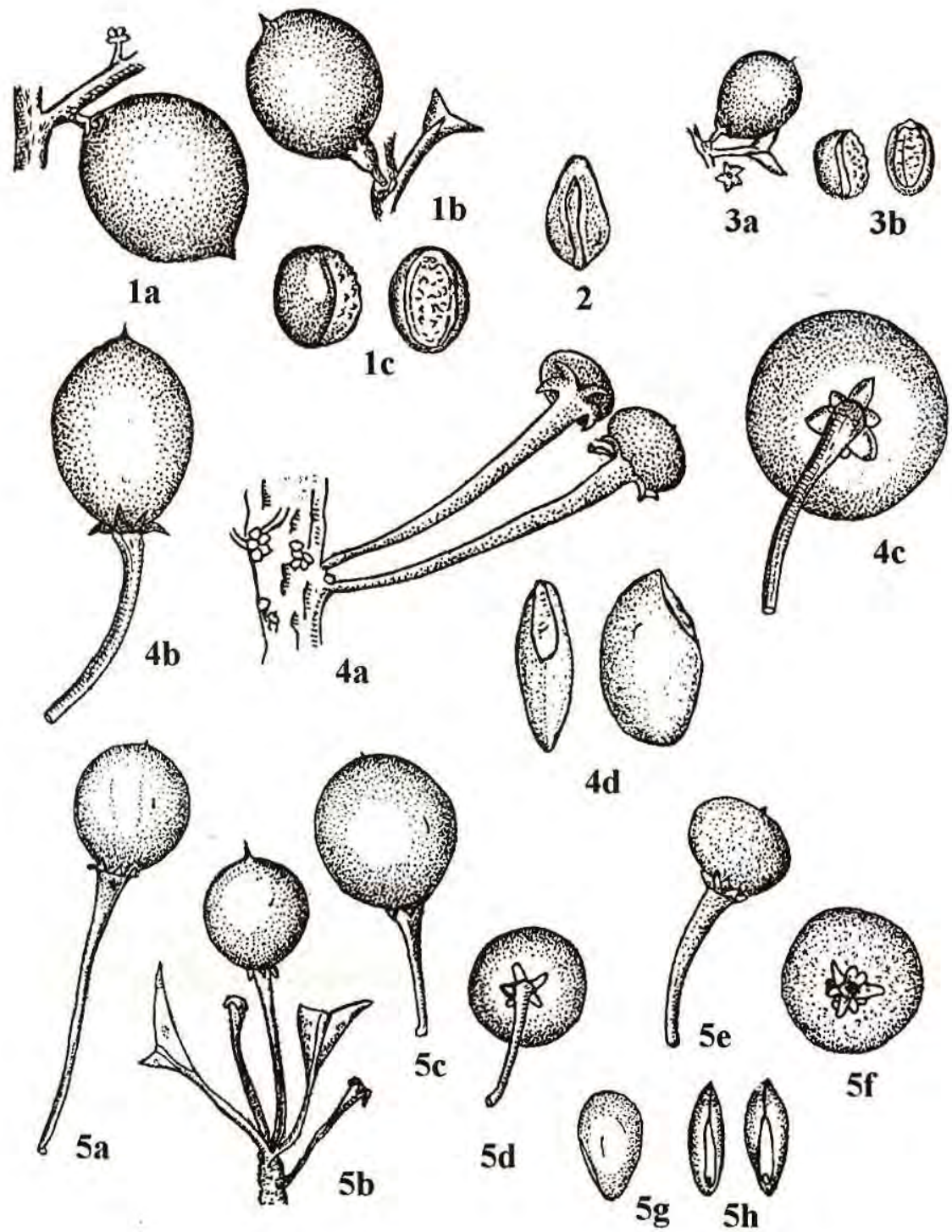

PI. 9. Figs. 1-5. SAPOTACEAE. 1. Elaeoluma glabrescens, a. fruit; b. fruit with different fruiting calyx; c. seed, lateral and frontal view (Van Roosmalen 100). 2. E. nuda, frontal view of seed (Amaral 1545). 3. E. schomburgkiana, a. fruit and fruiting calyx; b. seed, lateral and frontal view (Van Roosmalen 101). 4. Manilkara bidentata subsp. bidentata, a. young infructescence; b. fruit; c. fruit from below; d. seed, lateral and frontal view (Prevost 1072). 5. M. bidentata subsp. surinamensis, a,b,c. different fruits; d. fruit from below; e,f. different fruit, lateral and basal view; g. seed; h. seed, frontal view (Peres 319, 328, 343, 369; Defler 6, 83). 
Leaves thinly coriaceous, lower surface with dense, yellowish-brown indumentum, with ca. 16 pairs of secondary veins. Fascicles axillary, with 10-20 flowers; sepals $0.3-0.4 \mathrm{~cm}$ long; pedicels ca. $1.2 \mathrm{~cm}$ long. Fruit narrowly ellipsoid, ca. $2.5 \times 1 \mathrm{~cm}$, maturing orange, smooth; seeds 1 , laterally compressed, ca. $2.2 \times 0.6 \times 0.4 \mathrm{~cm}$, testa smooth, pale, not shining, scar basi-ventral, ca. $1.3 \times 0.2 \mathrm{~cm}$.

Notes. Tree to $21 \mathrm{~m}$ high and 40 $\mathrm{cm}$ diam., with small buttresses, slash with copious viscous white latex; nonflooded lowland rain forest, also found on savannas as small tree. Pará).

Distribution. Brazil (Amazonas, Manilkara excelsa (Ducke) Standley maparajuba (B) Pl. 10, fig. 1

Leaves rufous-brown tomentose below, with ca. 25 pairs of secondary veins. Fascicles with 5-10 flowers; fruiting sepals ca. $0.35 \mathrm{~cm}$ long; pedicels $1.5-2.2 \mathrm{~cm}$ long, at first rufous-brown tomentose, in fruit to 3.2 $\mathrm{cm}$ long, slender, thickened towards apex. Fruit broadly ellipsoid to subglobose, $1.5 \times 1.3 \mathrm{~cm}$ to $2.5 \times 2$ $\mathrm{cm}$, apex with a to $0.6 \mathrm{~cm}$ long prickle, yellowish-green, smooth; seeds 1, laterally compressed with a dorsal keel, $1.3 \times 0.8 \times 0.4 \mathrm{~cm}$, brown, shining, scar dull, $0.6 \mathrm{~cm}$ long.

Notes. Large tree to $40 \mathrm{~m}$ high and $70 \mathrm{~cm}$ diam., much smaller in rocky sites; periodically flooded forest.

Distribution. Brazil (S Amazonas, Mato Grosso, Pará; only found along the banks of the Rio Tapajós).

Manilkara huberi (Ducke) Chevalier basra-bortri, basra-boletri (S); maparajuba, massaranduba mansa (B) PI. 10, fig. 2

Leaves coriaceous, scurfypuberulous below, with $30-35$ pairs of secondary veins. Fascicles with 10-15 flowers; fruiting sepals $0.35-0.5 \mathrm{~cm}$ long, appressed puberulous; fruiting pedicels $2-4.2 \mathrm{~cm}$ long, thickened towards apex, appressed puberulous. Fruit broadly ovoid to subglobose, $2.5-3.2 \mathrm{x}$ $2.5-3.5 \mathrm{~cm}$, apex and base obtuse to rounded, apex with prickle, maturing yellowish-green or reddish, smooth; seeds 1 , laterally compressed, $2.3 \times 1.3$ x $0.5 \mathrm{~cm}$, light brown, shining, with a well-developed longitudinal dorsal keel, scar linear, $1.2 \times 0.15 \mathrm{~cm}$.

Notes. Tree to $50 \mathrm{~m}$ high and 2$3 \mathrm{~m}$ diam., with simple, steep, thick, to $2.5 \mathrm{~m}$ high buttresses and a cylindrical bole; bark deeply fissured, slightly cracked, greyish- to blackishbrown, inner bark pink with whitish streaks, slash with copious, sticky and white latex; $80 \mathrm{~km}$ north of Manaus, the author saw mature fruits being eaten by howling monkeys (Alouatta seniculus) and red-faced black spider monkeys (Ateles paniscus), both serving as proper seed dispersers (viable seeds were collected from feces), whereas goldenfaced sakis (Pithecia pithecia chrysocephala) fed on the immature seeds and the ripe pulp (Setz, 1993); lowland terra firme rainforest up to 700 $\mathrm{m}$ altitude, sometimes found in periodically flooded forest along white-water rivers (várzea).

Distribution. Brazil (Amapá, Amazonas, Mato Grosso, Pará, Rondônia, Roraima), Guianas, S. Venezuela. 
Manilkara inundata (Ducke) Ducke

maparajuba, massaranduba branca (B) PI. 10, fig. 3

Leaves chartaceous, glabrous, with 23-30 secondary veins. Fascicles with 4-5 flowers; sepals $0.4-0.5 \mathrm{~cm}$ long, puberulous; pedicels $1.3-1.8 \mathrm{~cm}$ long, finely puberulous, in fruit to $3.3 \mathrm{~cm}$ long, thickened toward apex. Fruit subglobose or ovoid, $1.5 \times 1.2 \mathrm{~cm}$, apex rounded, with a $0.4 \mathrm{~cm}$ long prickle, base truncate, maturing yellowish-green, smooth ; seeds 1 , laterally compressed, ca. 1.3 x $0.6 \times 0.4 \mathrm{~cm}$, testa smooth, scar basiventral, ca. $0.6 \times 0.2 \mathrm{~cm}$.

Notes. Tree to $50 \mathrm{~m}$ high and 1 m diam., sometimes buttressed, bark deeply fissured, slash red exuding copious viscous white latex; lowland rainforest on swampy ground, frequent in periodically flooded white-water (várzea) and permanently flooded black-water (igapó) forests.

Distribution. Am. Bolivia, Brazil (Acre, S Amazonas, Mato Grosso, Rondônia), Am. Colombia, Am Peru.

Manilkara paraensis (Huber) Standley

maparajuba, massaranduba, massarandubinha (B)

Leaves chartaceous, appressed puberulous below, with 12-18 pairs of secondary veins. Fascicles with 2-5 (7) flowers; sepals $0.3-0.5 \mathrm{~cm}$ long, appressed puberulous; pedicels $0.8-0.9 \mathrm{~cm}$ long, appressed puberulous. Fruit ellipsoid or subglobose, maturing pale yellowish-green, sometimes pinkish on one side; seeds 1 , small, with a turgid dorsal side without a longitudinal keel.

Notes. Tree to $40 \mathrm{~m}$ high and 40 $\mathrm{cm}$ diam., without buttresses, bark deeply fissured, greyish-brown, slash deep red, exuding copious sticky white latex; lowland terra-firme rainforest, to $450 \mathrm{~m}$ altitude.

Distribution. Brazil (Mato Grosso, Pará), Fr. Guiana.

Manilkara triflora (F. Allemão)

Monachino

massaranduba (B) Pl. 10, fig. 4

Leaves coriaceous, glabrous, with 12-17 pairs of secondary veins. Fascicles with 1-3 flowers; sepals ca. $0.35 \mathrm{~cm}$ long, appressed puberulous; pedicels $1-1.6 \mathrm{~cm}$ long, subglabrous. Fruit ellipsoid, $1.1 \times 0.8 \mathrm{~cm}$, apex rounded, with a stout $0.3 \mathrm{~cm}$ long prickle, base rounded, maturing orange or red, black when fully mature, smooth; seeds 1 , laterally compressed, ca. $0.8 \times 0.4 \times 0.25 \mathrm{~cm}$, keeled at the apex, testa smooth, brown, scar basiventral, ca. $0.2 \times 0.1 \mathrm{~cm}$.

Notes. Shrub or tree to $3(-8) \mathrm{m}$ high; dunes, sandy beaches, mangrove, caatinga and white sand savannas, up to $400 \mathrm{~m}$ altitude.

Distribution. Brazil (Maranhão, Pará).

\section{Micropholis (Grisebach) Pierre}

Leaves mostly spaced, alternate and distichous, sometimes spirally arranged, with closely parallel secondary veins, the leaf often appearing finely striate. Inflorescences axillary, ramiflorous or cauliflorous, fasciculate, sometimes developing into persistent short scaly shoots; flowers often unisexual, calyx a single whorl of (4-)5 free, imbricate or quincuncial sepals. Fruit a one- to several-seeded berry; seeds laterally compressed, testa often minutely transversely wrinkled, shining or dull, scar adaxial, extend- 
ing the length of the seed, usually narrow.

Notes. Trees or shrubs; 38 species in the Neotropics.

Micropholis section 1. Micropholis

$\underline{\text { Stamens included; corolla less }}$ than $1 \mathrm{~cm}$ long, lobes erect.

\section{Micropholis acutangula (Ducke)}

Eyma PI. 10, fig. 5

Leaves chartaceous, finely striate. Fascicles axillary, 1-12-flowered, sepals $4,0.1-0.3 \times 0.2 \mathrm{~cm}$; pedicels $0.4-0.8 \mathrm{~cm}$ long, in fruit $1.4-1.8 \mathrm{~cm}$ long. Fruit ellipsoid, $3.2 \times 1.1$ to 4.3 ($4.7) \times 2.2 \mathrm{~cm}$, strongly 4-ribbed (ribs 0.3-0.4 cm high) or 4-winged, apex narrowly attenuate, base acute or obtuse, maturing yellow-orange, smooth, glabrous, mesocarp rather dry, spongy; seeds $1,1.3-1.7 \times 0.7-1.0 \times 0.5-0.7 \mathrm{~cm}$, testa brown, shining, slightly wrinkled, scar dull, 0.3-0.4 cm wide.

Notes. Tree to $25 \mathrm{~m}$ high and 40 $\mathrm{cm}$ diam., flowering already when small, bark grey, slash exuding little white latex; $80 \mathrm{~km}$ north of Manaus, Amazonas, brown capuchin monkeys (Cebus apella apella) were seen feeding on the ripe pulp, swallowing and dispersing the seeds, whereas goldenfaced sakis (Pithecia pithecia chrysocephala) predated on the immature seeds (Setz, 1993); lowland terrafirme forest.

Distribution. Brazil (Amapá, C Amazonas, Pará), Fr. Guiana.

Micropholis casiquiarensis Aubréville abiurana-roxa (B) Pl. 10, fig. 6

Leaves thinly coriaceous, appearing striate. Fascicles in the axils of fallen leaves, ca. 10-flowered; sepals $5,0.2 \mathrm{~cm}$ long; pedicels $0.8-1.4 \mathrm{~cm}$ long, puberulous, in fruit thickened toward apex. Fruit ellipsoid, 2.1-3.3 x $1.8-2.5 \mathrm{~cm}$, yellow to dark red or almost black, shining, smooth, glabrous, apex rounded with prickle; seeds $1,1.7$ $2.1 \times 1-1.1 \times 0.6 \mathrm{~cm}$, testa wrinkled, scar wrinkled, to $0.4 \mathrm{~cm}$ wide.

Notes. Tree to $40 \mathrm{~m}$ and $60-90$ $\mathrm{cm}$ diam., with to $1 \mathrm{~m}$ high buttresses, bark flaking off in small vertical scales; ripe fruits were seen consumed by Geoffroy's woolly monkeys (Lagothrix lagotricha cana) dispersing the seeds intact, red-cap moustached tamarins (Saguinus mystax pileatus) and Ávila Pires' saddle-back tamarins (Saguinus fuscicollis avilapiresi) in the R. Urucú region, Amazonas (Peres, 1993, 1994), and by Humboldt's woolly monkeys (Lagothrix lagotricha lagotricha) on the lower R. Apaporis, E Colombia (Defler, pers. comm.), whereas the immature seeds were seen predated upon by Humboldt's blackheaded uacaries (Cacajao melanocephalus melanocephalus) along the R. Cauaburí in the Pico da Neblina National Park, NW Brazil (Boubli, 1997); terra-firme forest over clay, up to $1,100 \mathrm{~m}$ altitude.

Distribution. Brazil (Amazonas, N Pará), E Colombia, S Venezuela.

\section{Micropholis cylindrocarpa}

(Poeppig) Pierre

abiurana-roxa (B) PI. 11, fig. 1

Leaves thinly coriaceous, becoming glabrous, finely striate. Fascicles axillary or in the axils of fallen leaves, 1-2-flowered; flowers unisexual, sepals 5 , ca. $0.25 \mathrm{~cm}$ long; pedicels $0.1-0.2 \mathrm{~cm}$ long, pubescent, in fruit $0.3-0.4 \mathrm{~cm}$ long. Fruit ellipsoid, 


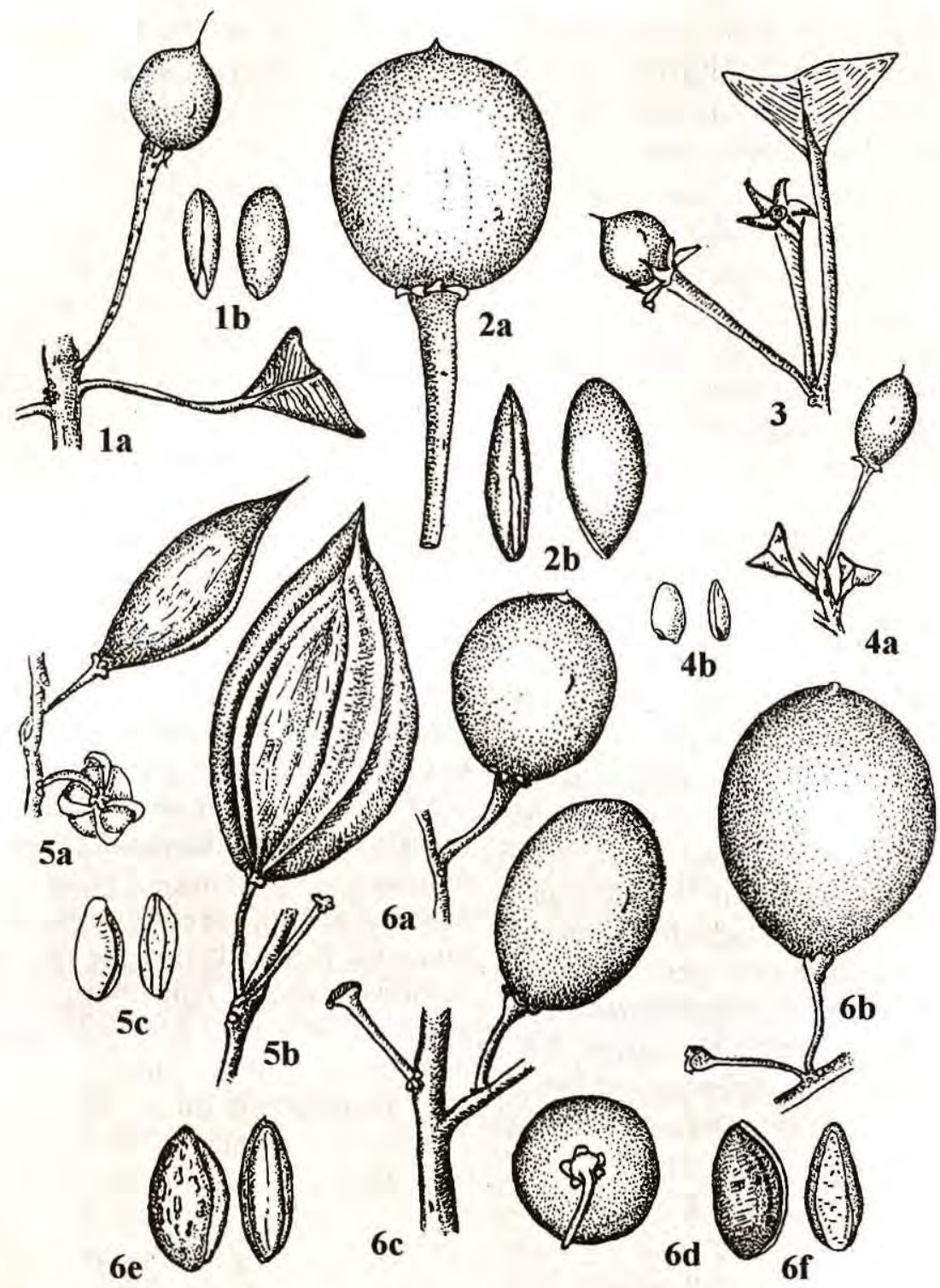

PI. 10. Figs. 1-6. SAPOTACEAE. 1. Manilkara excelsa, a. fruit; b. seed, frontal and lateral view (Van Roosmalen 97). 2. M. huberi, a. fruit; b. seed, frontal and lateral view (Van Roosmalen 96). 3. M. inundata (Krukoff 6624), 4. M. triflora, a fruit; b. seed, lateral and frontal view (Van Roosmalen 98). 5. Micropholis acutangula, a. young fruits; b. mature fruit; c. seed, lateral and frontal view (Setz 130; Van Roosmalen 66). 6. M. casiquiarensis, a,b,c. fruit; d. fruit from below; e,f. seed, lateral and frontal view (Peres 554, 667, 708). 
$2.5-3 \times 1.2-1.7 \mathrm{~cm}$, apex abruptly narrowed over $0.5 \mathrm{~cm}$, with prickle, base rounded, at first green, maturing purple, smooth, glabrous; seeds 1, 2.1 x $0.9 \times 0.5 \mathrm{~cm}$, with acute apex and base, testa minutely transversely wrinkled, brown, shining, scar $2 \times 0.2-$ $0.3 \mathrm{~cm}$, dull.

Notes. Tree to $15 \mathrm{~m}$ high and 25 cm diam., slash exuding white latex; in the R. Urucú region, Amazonas, ripe fruits were seen eaten by red-cap moustached (Saguinus mystax pileatus) and Ávila Pires' saddle-back (Saguinus fuscicollis avilapiresi) tamarins, and brown capuchin monkeys (Cebus apella)(Peres, 1993); lowland terrafirme rainforest, up to $150 \mathrm{~m}$ altitude.

Distribution. Brazil (W Amazonas, Acre), Peru.

Micropholis egensis (A. de Candolle)

Pierre in Pierre \& Urban

abiurana (B); bakoeman (S); kimboto, bakoeman.(P) Pl. 11, fig. 2

Leaves spaced, alternate and distichous, rarely spirally arranged, thinly coriaceous, finely striate. Fascicles axillary, 3-15-flowered; flowers unisexual, sepals 5(-6), 0.2-0.3 cm long; pedicels $0.3-0.9 \mathrm{~cm}$, in fruit to $1 \mathrm{~cm}$ long, puberulous. Fruit narrowly obovoid or ellipsoid, $2.5-3 \times 1.2 \mathrm{~cm}$, apex acuminate over $0.2-0.3 \mathrm{~cm}$, at first yellow, maturing reddish, purple or black, smooth, glabrous; seeds 1, 2-2.7 x 0.9-1 x $0.6 \mathrm{~cm}$, apex rounded, base tapered, testa rough, transversely wrinkled, pale brown, dull, scar 0.2$0.4 \mathrm{~cm}$ wide, widening towards apex and base, dull brown.

Notes. Tree to $40 \mathrm{~m}$ high and 60 $\mathrm{cm}$ diam., bole cylindrical, older trees with buttresses, bark grey to reddish brown, smooth or shallowly fissured, slash pink to orange, exuding sticky white latex; the immature seeds were seen predated upon by golden-faced sakis (Pithecia pithecia chrysocephala), north of Manaus, Am. Brazil (Setz, 1993); periodically flooded white water (várzea) and permanently flooded black water (igapó) forests, riverine forest, and sometimes terra-firme forest.

Distribution. Brazil (Acre, Amazonas, Rondônia), Am. Colombia, Fr. Guiana, Am. Peru, Suriname, Venezuela.

\section{Micropholis guyanensis (A. de} Candolle) Pierre subsp. guyanensis

lo-oedoe (S); wetibakoeman, mamamten (P); abiú, balata-brava/ rosadinha, mangabarana, maparajuba, caramory, rosadinha, rosada-mansa/ brava (B) Pl. 11, fig. 3

Leaves usually less than $15 \mathrm{~cm}$ long, 2-4 times as long as broad, spaced, alternate and distichous or spirally arranged, coriaceous, pale buff or bronze sericeous below, with 15-20 secondary veins, sometimes appearing more or less striate. Fascicles axillary, 2-20-flowered, usually developing into stout, recurved, lepidote, $0.2-1 \mathrm{~cm}$ long shoots, persisting on the old wood, flowers unisexual; sepals 5, 0.2$0.4 \mathrm{~cm}$ long, golden to ferruginous puberulous; pedicels $0.4-0.7 \mathrm{~cm}$ long, in fruit to $1(-1.5) \mathrm{cm}$ long, puberulous. Fruit ellipsoid or obovoid, $2.2 \times 1.3 \times$ $1.1 \mathrm{~cm}$ to $3.2 \times 2.3 \mathrm{~cm}$, apex rounded, with prickle slightly sunken in, leaving a circular $0.2-0.7 \mathrm{~cm}$ diam. patch, base rounded or tapered, at first green to yellow, maturing reddish-brown to 
purplish-black, smooth, at first finely light brown appressed puberulous, often glabrescent, epicarp soft, pulp soft, white, transparent, sweet-tasting; seeds $1(-2), 1.7-2.1 \times 0.9-1 \times 0.7-0.8 \mathrm{~cm}$, testa brownish-black, smooth, shining, scar dull, white, $0.3-0.4 \mathrm{~cm}$ wide at base, narrowing to $0.1 \mathrm{~cm}$ at apex.

Notes. Tree to $40 \mathrm{~m}$ high and 1 $\mathrm{m}$ diam., older specimens with to $2 \mathrm{~m}$ high flat buttresses, bark (reddish)brown, smooth or finely fissured, slash pink or orange exuding sticky white latex; in Suriname, red-faced black spider monkeys (Ateles paniscus) fed on the mature pulp dispersing the seeds endochorically; the immature seeds were seen heavily predated upon by black bearded sakis (Chiropotes satanas chiropotes) (Frazão, 1992) and golden-faced sakis (Pithecia pithecia chrysocephala) (Setzl, 1993) in the forests north of Manaus, Am. Brazil, over a prolonged period of time, whereas Peres (pers. comm.), in the R. Urucú region, saw brown capuchins (Cebus apella) predating on immature seeds, and whitefaced capuchins (Cebus albifrons unicolor), Ávila Pires' saddle-back tamarins (Saguinus fuscicollis avilapiresi), red-cap moustached tamarins (Saguinus mystax pileatus) (Peres, 1993), and Geoffroy's woolly monkeys (Lagothrix lagotricha cana) feeding on mature fruits (Peres, 1994), and found viable seeds in the feces of the woolly monkeys in the area, and Defler (pers. comm.), working in the lower R. Apaporis region of Amazonian Colombia, saw Humboldt's woolly monkeys (Lagothrix lagotricha lagotricha) feeding on the mature fruits, swallowing and dispersing the seeds; lowland seasonal semi-evergreen forest, usually but not always on non-flooded land.

Distribution. Bolivia, Brazil (Acre, Amapá, Amazonas, Pará, Rondônia), Colombia, Guianas, Peru, Venezuela.

Micropholis guyanensis (A. de Candolle) Pierre subsp. duckeana (Baehni) Pennington

abiú-balatarana, balata-rosada/ rosadinha, rosada-brava/verdadeira, rosadinha-brava/grande (B) PI. 11, fig. 4

Leaves usually more than $15 \mathrm{~cm}$ long, about twice as long as broad, conspicuously tan, rufous or golden below. Inflorescences as in subsp. guyanensis. Fruft ellipsoid, $1.2 \times 0.8$ to $2.5(-2.8) \times 2.1(-2.6) \mathrm{cm}$, at first greenish-brown, maturing olive-green to yellow, with an easily removed ferruginous pubescence, apex with stout prickle, pulp juicy, fruiting calyx accrescent, sepals rounded, $0.4 \times 0.5$ $\mathrm{cm}$, ferruginous puberulous; seed 1.3$1.7(-2.0) \times 0.9 \times 0.6 \mathrm{~cm}$, weighing 4 grams, testa rough, finely transversely wrinkled, scar $0.25-0.4 \mathrm{~cm}$ wide.

Notes. Tree to $30 \mathrm{~m}$ high and 30 $\mathrm{cm}$ diam., slash exuding copious white or yellowish sticky latex, the latex was formerly used in Amazonian Peru as a substitute for 'balata'; in the R. Urucú region, Peres (1994) observed brown capuchin monkeys (Cebus apella) and Geoffroy's woolly monkeys (Lagothrix lagotricha cana) feeding on mature fruits, dispersing the seeds endochorically, whereas Ávila 
Pires' saddle-back tamarins (Saguinus fuscicollis avilapiresi) and red-cap moustached tamarins (Saguinus mystax pileatus) fed on the ripe pulp without swallowing the seeds (Peres, 1993), and buffy sakis (Pithecia albicans) predated on the immature seeds; non-flooded lowland forest over clay or white sand, to $250 \mathrm{~m}$ altitude.

Distribution. Brazil (Acre, Amapá, Amazonas, Mato Grosso, Rondônia), Am. Colombia, Fr. Guiana, Am. Peru, Am. Venezuela.

\section{Micropholis humboldtiana (Roemer \\ $\&$ Schultes) Pennington \\ abiurana-murta, massarandubinha \\ (B) Pl. 11, fig. 5}

Leaves coriaceous, appressed ferruginous sericeous below, finely striate. Fascicles axillary and in the axils of fallen leaves, 1-3-flowered, flowers unisexual, sepals 5, 0.25-0.4 cm long, appressed pubescent; pedicels $0.2-0.4 \mathrm{~cm}$ long, ferruginous pubescent. Fruit ellipsoid, $1.5 \times 0.9$ $\mathrm{cm}$, apex shortly rostrate with prickle, maturing dark wine-red, brownpuberulous.

Notes. Tree to $15 \mathrm{~m}$ high and 12 $\mathrm{cm}$ diam., without buttresses, slash reddish, exuding little white latex; black water flooded forest (igapó) and periodically flooded savannas.

Distribution. Brazil (Amazonas, Rio Negro basin), Venezuela (Amazonas).

\section{Micropholis longipedicellata}

Aubréville Pl. 11, fig. 6

Leaves chartaceous, glabrous, finely striate. Fascicles axillary, 1-5flowered, flowers unisexual, sepals 5,
0.25-0.4 cm long, hairy outside; pedicels $0.5-2.5 \mathrm{~cm}$ long, pubescent, in fruit up to $4 \mathrm{~cm}$ long. Fruit ellipsoid, 2.1-3.5 x 1.4-1.7 cm, apex acute, base rounded or acute, maturing yellow, epicarp hard, smooth, glabrous; seeds 1-several, $1.8-2.2 \times 0.6 \mathrm{~cm}$, tapering toward base and apex, testa smooth, shining, scar $0.2 \mathrm{~cm}$ wide.

Notes. Tree to $15 \mathrm{~m}$ high and 20 $\mathrm{cm}$ diam., without buttresses, bark reddish-grey to dark brown, scaling, slash orange-yellow, exuding little white latex; terra-firme rain and savanna forest between 200 and 750 metres altitude, often on swampy places. Guianas.

Distribution. Brazil (Amapá),

\section{Micropholis madeirensis (Baehni)}

Aubréville PI. 11, fig. 7

Leaves thinly coriaceous, tomentose below, but indumentum persisting only on midrib and veins, with 40-50 pairs of secondary veins. Fascicles axillary and in the axils of fallen leaves, 1-10-flowered, flowers unisexual, sessile, sepals 5 , ca. $0.4 \mathrm{~cm}$ long, densely ferruginous-tomentose outside, slightly accrescent in fruit. Fruit narrowly ellipsoid, $2.5-3 \times 1.5$ $\mathrm{cm}$, apex acute, base broadly tapered, smooth, tomentose; seeds 1 .

Notes. Tree to $30 \mathrm{~m}$ high, slash exuding white latex; lowland rainforest to $200 \mathrm{~m}$ altitude.

Distribution. Brazil ( $\mathrm{C}$ and W Amazonas), Am. Peru.

\section{Micropholis melinoniana Pierre}

mamanten (P) PI. 12, fig. 1

Leaves thinly coriaceous, glabrous, finely striate. Fascicles axillary 


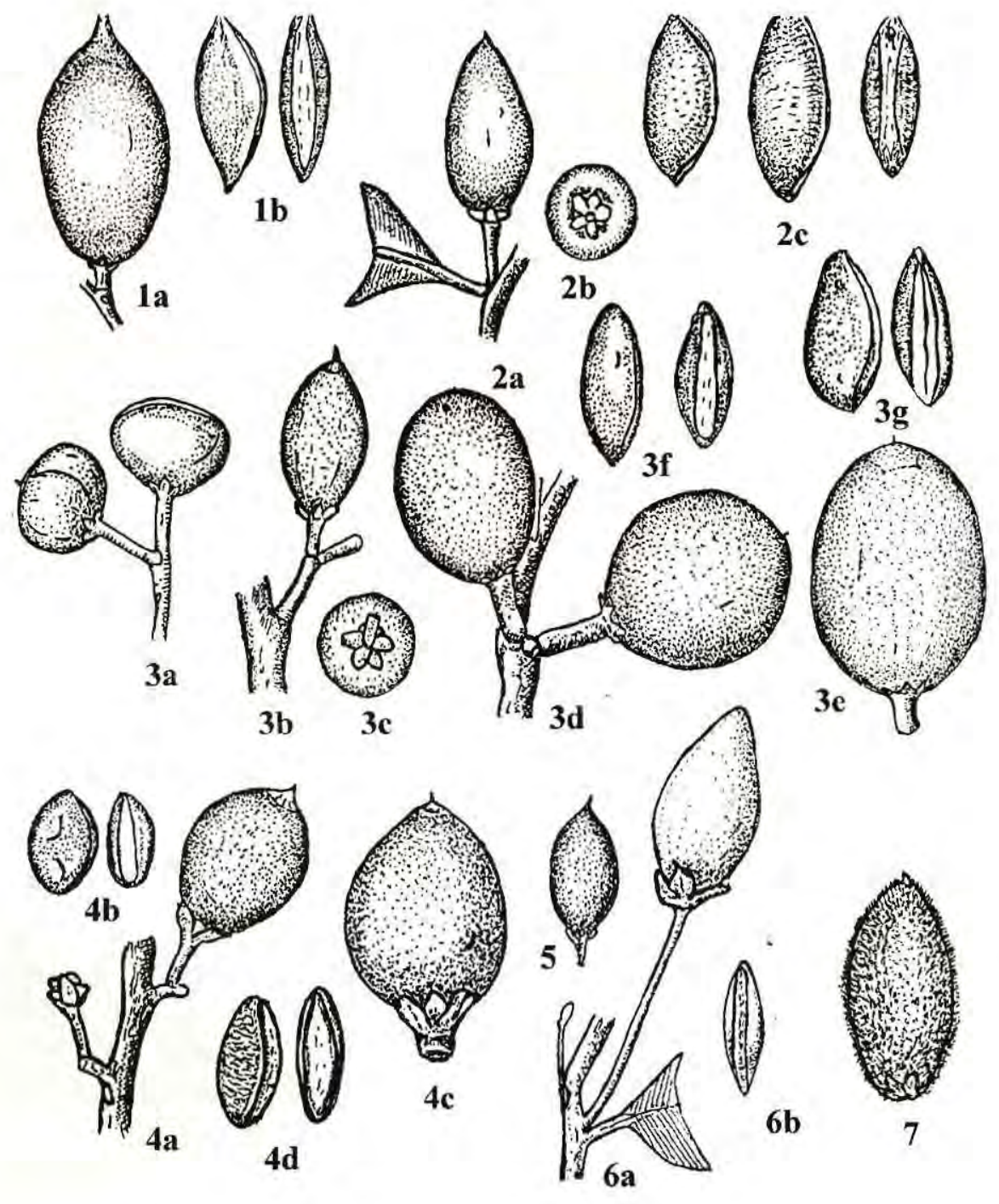

PI. 11. Figs. 1-7. SAPOTACEAE. 1. Micropholis cylindrocarpa, a. fruit; b. seed, lateral and frontal view (Peres $367,439,441$ ). 2. M. egensis, a. young fruit; b. young fruit from below; c. seed, lateral and frontal view (Van Roosmalen 85). 3. M. guyanensis subsp. guyanensis, a. young fruits; b. young fruit; c. young fruit from below; d,e. ripe fruits; $f, g$. seed, lateral and frontal view (Defler 6; Peres 480, 516). 4. M. guyanensis subsp. duckena, a. fruit; seed, lateral and frontal view; c. other fruit; d. seed, lateral and frontal view (Peres I56, 467). 5. M. humboldtiana (Rodrigues 6097). 6. M. longipedicellata, a. fruit; b. seed, frontal view (Tillett et al. 45029). 7. M. madeirensis (Vásquez 2044). 
or in the axils of fallen leaves, 5-15flowered, flowers unisexual, sepals 5 , $0.2-0.3 \mathrm{~cm}$ long, appressed puberulous; pedicels $0.2-0.6 \mathrm{~cm}$ long, appressed puberulous. Fruit broadly ellipsoid, 4-7 $\mathrm{cm}$ long, apex and base acute or obtuse, maturing yellow, orange, reddish or purple, epicarp thick, smooth, sometimes slightly sulcate, glabrous; seeds 1several, $2.5-2.6 \times 1.2 \mathrm{~cm}$, testa smooth, shining, scar $0.4-0.6 \mathrm{~cm}$ wide.

Notes. Tree to $40 \mathrm{~m}$ and $1.5 \mathrm{~m}$ diam., with thick, to $2 \mathrm{~m}$ high buttresses and cylindrical bole, bark smooth to finely fissured, greyishbrown, slash cream-brown to reddish, exuding sticky white or cream latex; fruits are reported to be eaten by macaws (Ara spp.); lowland terra-firme rainforest.

Distribution. Brazil (Acre, Amapá, Pará, Roraima), Fr. Guiana, Peru, Venezuela.

\section{Micropholis mensalis (Baehni)}

Aubréville

\section{fig. 2}

abiurana, goiabinha (B) Pl. 12,

Leaves chartaceous, glabrous, appearing striate. Fascicles axillary or in the axils of fallen leaves, 1-4-flowered, sepals $5,0.3-0.5 \mathrm{~cm}$ long, sericeous; pedicels $0.5-0.7 \mathrm{~cm}$ long, appressed puberulous. Fruit ellipsoid, to $5 \times 2-2.5 \mathrm{~cm}$, apex long attenuate (rostrate), base acute, epicarp soft, smooth, glabrous; seeds $1-2$, ca. 2.5 $\mathrm{cm}$ long, base and apex acute, testa rough, minutely transversely wrinkled, dull, scar $0.3 \mathrm{~cm}$ wide.

Notes. Tree to $12 \mathrm{~m}$ high and 20 $\mathrm{cm}$ diam., bark greyish-brown, slash exuding little white latex; lowland terra -firme forest and on granitic inselbergs to $1,000 \mathrm{~m}$ altitude.

Distribution. Brazil (C and W Amazonas, Pará), Guianas.

Micropholis porphyrocarpa (Baehni) Monachino Pl. 12, fig. 3

Leaves spaced, spirally arranged or alternate and distichous, coriaceous, densely sericeous-pubescent below. Fascicles axillary, 1-10-flowered, flowers unisexual, sessile, sepals 5 , $0.3-0.4 \mathrm{~cm}$ long, densely pubescent; fruiting pedicels $0-0.9 \mathrm{~cm}$ long, brown-pubescent. Fruit narrowly ellipsoid, $1.8-2.1 \times 1.5 \mathrm{~cm}$, to $3 \mathrm{~cm}$ long, apex rostrate with prickle, base rounded, at first green, maturing deep purple or black, smooth or slightly longitudinally ribbed, brown-pubescent to glabrescent; seeds $1,1.5-1.7 \mathrm{x}$ $0.9 \times 0.5 \mathrm{~cm}$, testa minutely transversely wrinkled, blackish-brown, shining, scar $0.2-0.3 \mathrm{~cm}$ wide, white.

Notes. Tree to $35 \mathrm{~m}$ high and 60 $\mathrm{cm}$ diam., with steep narrow to $1.5 \mathrm{~m}$ high buttresses, tapering into a fluted bole, bark (orange-)brown, scaling irregularly, slash orange to pale cream, laminated, exuding (yellowish-)white sticky latex; immature seeds are predated upon by golden-faced sakis (Pithecia pithecia chrysocephala), as was observed in the forests north of Manaus, Amazonas (Setz, 1993), whereas in the R. Urucú region, Amazonas, two species of tamarin (Saguinus fuscicollis avilapiresi and Saguinus mystax pileatus) were seen feeding on the mature pulp (Peres, 1993); upland terra-firme rainforest, to $500 \mathrm{~m}$ altitude. 
Distribution. Brazil (Acre, Amapá, Amazonas, Pará, Rondônia), Fr. Guiana, Guyana, Am. Peru.

Micropholis resinifera (Ducke) Eyma

balata, balata-rosadinha (B)

Leaves coriaceous, very broad, with 20-24 pairs of prominent secondary veins, brown appressed puberulous below. Fascicles axillary, 5-10-flowered, sepals 5, 0.4-0.5 cm long; pedicels $0.6-0.8 \mathrm{~cm}$ long, appressed puberulous. Fruit similar to that of $M$. guyanensis subsp. guyanensis.

Notes. Tree to $50 \mathrm{~m}$ high with cracked bark; lowland terra firme rainforest.

Distribution. Brazil

(W Amazonas).

Micropholis sanctae-rosae (Baehni)

Pennington

mangabarana (B)

Leaves thinly coriaceous, appressed pubescent below, with (2540-50 pairs of secondary veins. Fascicles axillary, several-flowered, flowers unisexual, sepals $5,0.3-0.35 \mathrm{~cm}$ long, appressed pubescent; pedicels ca. $0.1 \mathrm{~cm}$ long, pubescent. Fruit when immature oblong, ca. $1 \mathrm{~cm}$ long, densely velutinous-villose, mature fruits not seen.

Notes. Tree to $20 \mathrm{~m}$ high and 20 cm diam.; lowland terra-firme rainforest.

Distribution. Brazil (Amapá, Pará), Fr. Guiana, Peru.

\section{Micropholis trunciflora Ducke}

abiurana, rosada-brava (B) PI.

\section{2, fig. 4}

Leaves thinly coriaceous, glabrous, finely striate. Fascicles axillary or in the axils of fallen leaves, and cauliflorous, densely clustered on large (several centimetres diam.) protuberances on the trunk, 1-6-flowered, flowers unisexual, sepals (4-)5, $0.15-0.25 \mathrm{~cm}$ long, pubescent; pedicels $0.2-0.5 \mathrm{~cm}$, in fruit $0.5-0.7 \mathrm{~cm}$ long, shortly tomentose. Fruit ellipsoid to globose, $1.3-2.5 \times 1.2 \mathrm{~cm}$, apex acute to rounded, acuminate over $0.15 \mathrm{~cm}$, with prickle, base acute to rounded, green to yellow, maturing dark blue or purple, longitudinally five times sulcate, glabrous; seeds $1,1.3-1.5 \times 0.7$ x $0.6 \mathrm{~cm}$, testa finely transversely wrinkled, black, shining, apex acuminate, scar $0.2-0.3 \mathrm{~cm}$ wide, white.

Notes. Tree to $42 \mathrm{~m}$ high and 40 $\mathrm{cm}$ diam., with cylindrical bole, slash exuding little white latex, the inflorescences sometimes so dense that they cover $2 / 3$ of the trunk surface, the trunk of an $8 \mathrm{~m}$ high tree was seen covered with fruits between 1.5 and $6 \mathrm{~m}$ high; the flowers are observed being eaten by black bearded sakis (Chiropotes satanas chiropotes) in the forests north of Manaus, Amazonas (Frazão, 1992), and by buffy sakis (Pithecia albicans) in the R. Urucú region, Amazonas (Peres, pers. comm.), whereas north of Manaus golden-faced sakis (Pithecia pithecia chrysocephala) were seen predating on the immature seeds (Setz, 1993), and Guianan brown capuchin monkeys (Cebus apella apella) feeding on the mature pulp; lowland primary rainforest, usually on non-flooded land.

Distribution. Brazil (Acre, C and W Amazonas), Peru.

Micropholis venulosa (Martius \& Eichler) Pierre 
k(i)udibushi, moraballi (A); riemhout (SD); mamanten, wetibakoeman (P); abiú, mulungu, piramiry, rosadinha, rosada-verde (B) Pl. 12, fig. 5

Leaves small, sometimes spirally arranged, chartaceous or thinly coriaceous, glabrous, finely striate. Fascicles axillary, 3-15-flowered, flowers unisexual, sepals 4(-5), 0.15-0.2(-0.3) $\mathrm{cm}$ long, reddish-brown puberulous, in fruit up to $0.4 \mathrm{~cm}$ long; pedicels 0.2 $0.5 \mathrm{~cm}$ long, reddish-brown puberulous, in fruit $0.4-0.9 \mathrm{~cm}$ long. Fruit subglobose to broadly ellipsoid, $1.2-2.4(-3.4) \times 1.2-1.7(-2.2) \mathrm{cm}$, apex and base acute to rounded, apex often acuminate over $0.2-0.4 \mathrm{~cm}$, maturing yellow or tinged red or lilac-brown, smooth, glabrous, pulp sweet-tasting; seeds 1(-2), (1.0-)1.5-2.1 x 0.6-1.2 x $0.4-0.7 \mathrm{~cm}$, weighing 32 grams $(\mathrm{n}=7)$, testa finely transversely wrinkled, light brown, shining, scar sometimes extending around the base of the seed, 0.15$0.5 \mathrm{~cm}$ wide, dull.

Notes. Tree to $40 \mathrm{~m}$ high and $100 \mathrm{~cm}$ diam., exceptional specimens are said to reach $70 \mathrm{~m}$ (!) high and 1.5 $\mathrm{m}$ diam. above the up to $3 \mathrm{~m}$ high steep buttresses, bole cylindrical or fluted, bark greyish-brown, finely fissured or more often scaling, reputed to have medicinal properties, slash reddish-brown, exuding plentiful white latex; seeds reputed to be dispersed by many birds, in Suriname red howling monkeys (Alouatta seniculus seniculus) were several times seen feeding on the mature pulp dispersing the seeds endochorically, whereas in the R. Urucú region, Amazonas, Brazil, buffy sakis (Pithecia albicans) and brown capuchin monkeys (Cebus apella) were seen feeding on ripe pulp (Peres, pers. comm.), and in the forests north of Manaus, black bearded sakis (Chiropotes satanas chiropotes) were seen predating upon the immature seeds (Frazão, 1992); terra firme lowland rainforest up to $700 \mathrm{~m}$ altitude, also found in periodically whitewater flooded forest (várzea), in permanently black-water flooded forest (igapó), in dwarf savanna forest on white sand (campina), and wet montane forest to $900 \mathrm{~m}$ altitude.

Distribution. Brazil (Acre, Amazonas, Pará, Rondônia), Colombia, Guianas, Peru, Venezuela.

Micropholis williamii Aubréville \& Pellegrin

balata-brava (B) PI. 12, fig. 6

Leaves coriaceous, pubescent below, with $30-45$ pairs of secondary veins. Fascicles axillary, 5-10-flowered at first, developing into dense, many-flowered clusters on $0.5-1 \mathrm{~cm}$ long protuberances, flowers with 5 sepals, 0.2-0.3 cm long, densely velutinous-pubescent; pedicels 0.1 $0.15 \mathrm{~cm}$ long, stout and tapering from the calyx base. Fruit oblong-ellipsoid, $2.3 \times 1.2 \times 1 \mathrm{~cm}$, apex rounded, with prickle, base tapered, densely brown velutinous-hispid, smooth; seeds 1 , (1.1-) $1.7 \times 0.7 \times 0.4-0.5 \mathrm{~cm}$, testa blackish-brown, shining, smooth, scar extending the full length of the seed, $0.15-0.2 \mathrm{~cm}$ wide, lightbrown.

Notes. Tree to $22 \mathrm{~m}$ high and 20 $\mathrm{cm}$ diam., with horizontally spreading branches, slash exuding white latex; wet lowland rainforest on non-flooded land usually over clay. 

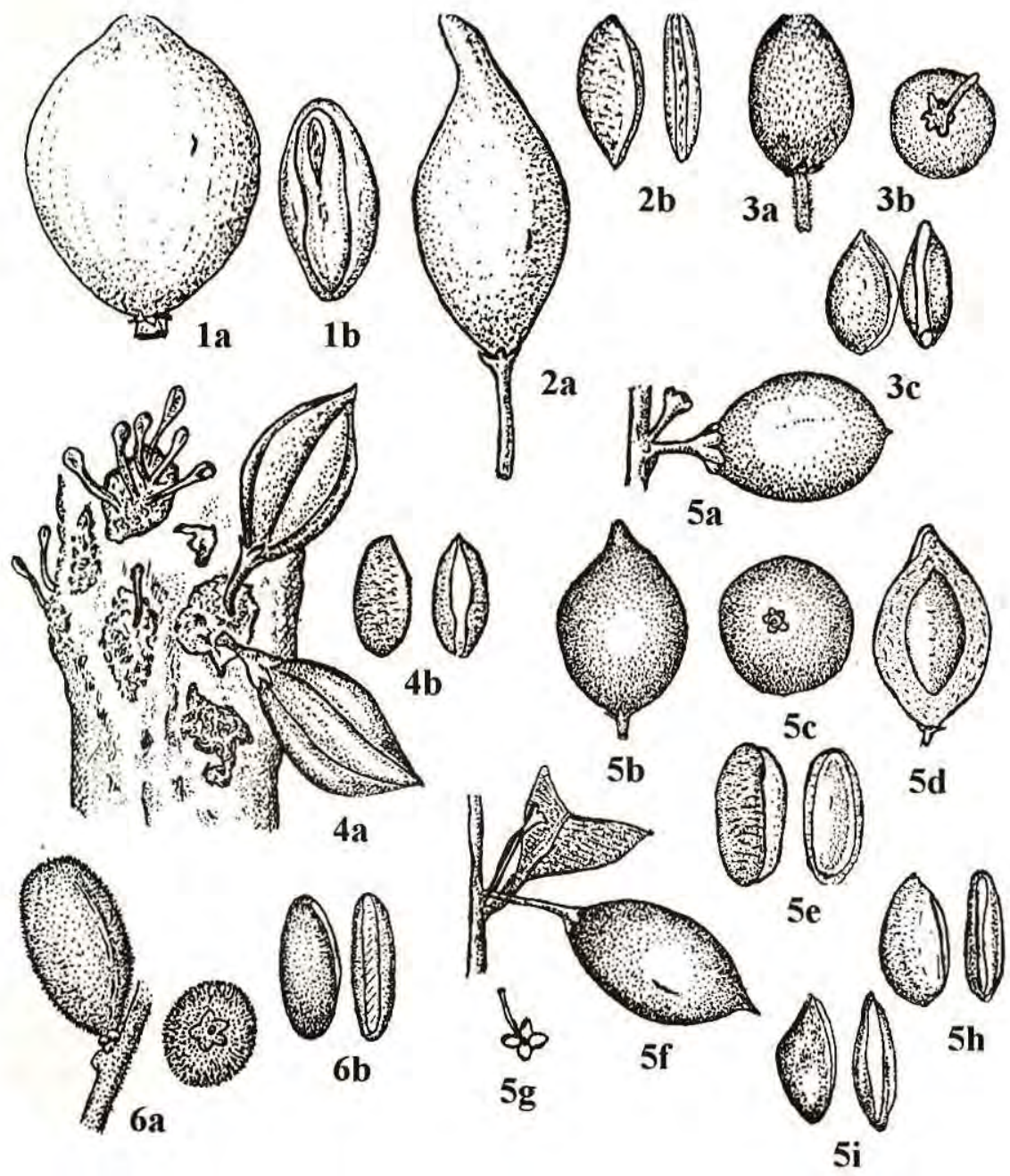

PI. 12. Figs. 1-6. SAPOTACEAE. 1. Micropholis melinoniana, a. fruit; b. seed, frontal view (De Granville 4267). 2. M. mensalis, a. fruit; b. seed, lateral and frontal view (Tillett et al. 45192). 3. $M$. porphyrocarpa, a. fruit; b. fruit from below; c. seed, lateral and frontal view (Setz 139; Peres 689). 4. M. trunciflora, a. infructescence; b. seed, lateral and frontal view (Van Roosmalen 87; Setz 154). 5. M. venulosa, a,b. fruit; c. fruit from below; d. fruit, longitudinal section; e. seed, lateral and frontal view; f. other fruit; g. fruiting calyx; h,i. seed, lateral and frontal view (Peres 317; Frazão 57). 6. M. williamii, a. fruit, lateral and basal view; b. seed, lateral and frontal view (Van Roosmalen 91). 
Distribution. Brazil Amazonas, Pará).

Micropholis section 2. Exsertistamen Pennington

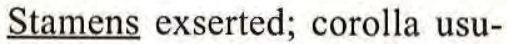
ally more than $1 \mathrm{~cm}$ long, lobes spreading or reflexed.

\section{Micropholis caudata Pennington Pl. 13, fig. 1}

Leaves spaced, alternate or in lax spirals, coriaceous, glabrous, finely striate. Fascicles ramiflorous, 5-12-flowered, sepals $5,0.7-0.8 \mathrm{~cm}$ long, in fruit ca. 1 × $0.8 \mathrm{~cm}$, finely puberulous; pedicels $1.3-1.7 \mathrm{~cm}$ long, expanded below the calyx, finely puberulous. Fruit ellipsoid to obovoid, $3 \times 1.7-2.2 \mathrm{~cm}$, apex rounded and abruptly acuminate, forming a stout $0.5 \mathrm{~cm}$ long prickle, green, maturing yellow, epicarp thin, coriaceous, smooth, finely puberulous toward apex; seeds 1, 1.7-2.3 x 1.0-1.2 $x$ 0.7-0.9 $\mathrm{cm}$, weighing 7.5 grams $(n=8)$, apex obliquely acuminate, base acute, testa blackish-brown, shining, finely transversely wrinkled, scar extending the full length of the seed, $0.3-0.4 \mathrm{~cm}$ wide, dull.

Notes. Tree 25(-40) $\mathrm{m}$ high and $25 \mathrm{~cm}$ diam., slash exuding white latex; in the R. Urucú region, Amazonas, the mature pulp was seen eaten by two species of tamarin monkeys (Saguinus fuscicollis avilapiresi and Saguinus mystax pileatus) (Peres, 1993), by brown capuchin monkeys (Cebus apella), by dusky and collared titi monkeys (Callicebus cupreus cupreus and Callicebus torquatus purinus), and by Geoffroy's woolly monkeys (Lagothrix lagotricha cana)(Peres, 1994), whereas the seeds were endochorically dispersed only by the capuchins and the woolly monkeys (Peres, pers. comm.); only a single botanical collection known from lowland terra-firme rainforest.

Distribution. Brazil (C and S Amazonas).

\section{Micropholis cayennensis \\ Pennington PI. 13, fig. 2}

Leaves coriaceous, glabrous or golden appressed puberulous below, coarsely striate. Fascicles ramiflorous, many-flowered, sepals $5,0.4-0.5 \mathrm{~cm}$ long, appressed puberulous; pedicels $1.0-1.3 \mathrm{~cm}$ long, appressed puberulous. Fruit ovoid, ca. $5 \times 3 \mathrm{~cm}$, apex truncate, with stout prickle, epicarp smooth, glabrous; seeds 1, ca. $1.8 \mathrm{~cm}$ long, apex rounded, base acute, testa smooth, shining, scar extending the full length of the seed, $0.2-0.25 \mathrm{~cm}$ wide.

Notes. Tree to $31 \mathrm{~m}$ high and $50 \mathrm{~cm}$ diam., with steep, simple, to 1.5 $\mathrm{m}$ high buttresses, bole usually cylindrical, bark brown, scaling in thin rectangular pieces, slash cream with brown, exuding little sticky white or yellowish latex; lowland terra-firme rainforest, frequent on slopes and ridge tops at $150-500 \mathrm{~m}$ altitude.

Distribution. Brazil (Amapá), Fr. Guiana.

\section{Micropholis grandiflora Aubréville}

Leaves coriaceous, glabrous, with ca. 60 pairs of secondary veins, not striate. Fascicles axillary and ramiflorous, 10-15-flowered, flowers large, sepals 5 , ca. $1 \mathrm{~cm}$ long, subglabrous; pedicels $1.2-1.3 \mathrm{~cm}$ long, minutely appressed puberulous. Fruit not known.

Notes. Tree to $30 \mathrm{~m}$ and $50 \mathrm{~cm}$ 
diam., slash exuding white latex; terrafirme rainforest between 800 and $1,000 \mathrm{~m}$ altitude.

Distribution. Brazil (NW Amazonas; only once collected in the Pico da Neblina National Park).

Micropholis maguirei Aubréville

rosadinha (B)

Leaves coriaceous, ferruginoustomentellous below, finely striate. Fascicles ramiflorous, 5-12-flowered, flowers large, sepals $5,0.9-1.0 \mathrm{~cm}$ long, ferruginous-tomentellous; pedicels $0.5-1.0 \mathrm{~cm}$ long, shortly ferruginous-tomentose. Fruit ovoid when immature, ca. $2 \mathrm{~cm}$ long, apex rostrate, base rounded, smooth, rufous-brown pubescent.

Notes. Tree to $25 \mathrm{~m}$ high and 30 $\mathrm{cm}$ diam., with narrow, to $1 \mathrm{~m}$ high buttresses, slash exuding little white latex; lowland terra-firme rainforest at 100-200 m altitude.

Distribution. Brazil (NW Amazonas), Venezuela (S. Amazonas).

\section{Micropholis obscura Pennington}

ufu (A); bakouman (P); abiuranade-massa (B) PI. 13, fig. 3

Leaves coriaceous, glabrous, finely striate. Fascicles in the axils of fallen leaves, 5-15-flowered, flowers small, sepals 5 , ca. $0.3 \mathrm{~cm}$ long, appressed puberulous; pedicels $0.5-0.7$ $\mathrm{cm}$ long, glabrous. Fruit broadly ellipsoid, 1.6-1.9(-3) x 1.2-1.4 cm, apex rounded, with a prickle, base obtuse, at first green, maturing yellow or yellowish brown, smooth, glabrous, the pulp sweet, tasting of apple or prune; seeds $1,1.1-1.6 \times 0.5-1 \mathrm{~cm}$, with an abaxial keel, apex and base obtuse, testa smooth, shining, scar extending the full length of the seed, $0.45 \mathrm{~cm}$ wide; seed weight 1.6 grams $(n=8)$.

Notes. Tree to $35 \mathrm{~m}$ high and 85 $\mathrm{cm}$ diam., with large, to $1.5 \mathrm{~m}$ high, thin, convex buttresses, bole cylindrical or slightly fluted near base, bark reddish-brown, scaling in large irregular plates, slash brown or yellow with brown streaks, exuding little white or cream latex; in the R. Urucú region, two species of tamarin (Saguinus fuscicollis avilapiresi and Saguinus mystax pileatus) and collared titi monkeys (Callicebus torquatus purinus) were seen feeding on the mature pulp, swallowing and dispersing the seeds (Peres, 1993); seasonal semi-evergreen forest between 200 and $400 \mathrm{~m}$ altitude, sometimes in black water flooded forest (igapó).

Distribution. Brazil (Amazonas, Pará), Guyana, Fr. Guiana, S Venezuela, Am. Peru.

\section{Micropholis splendens Gilly ex}

Aubréville Pl. 13, fig. 4

Leaves spaced, spirally arranged, coriaceous, densely rufous-brown appressed puberulous below, finely striate. Fascicles ramiflorous, 5-10-flowered, flowers large, sepals $6,0.7-0.8$ $\mathrm{cm}$ long, minutely appressed puberulous; pedicels $1-1.7 \mathrm{~cm}$ long, appressed puberulous. Fruit ellipsoid, 3-3.7 cm long, apex narrowly rostrate, base acute, glaucous-green, smooth, at first with rufous hairs, glabrescent; seeds 1 , ca. $2.2 \mathrm{~cm}$ long, testa smooth, shining, scar ca. $0.8 \mathrm{~cm}$ wide, extending the length of the seed.

Notes. Tree to $30 \mathrm{~m}$ and $50 \mathrm{~cm}$ diam., larger specimens with buttresses, slash exuding white or yellow- 
ish latex; terra-firme rainforest up to $800 \mathrm{~m}$ altitude.

\section{Distribution. Brazil (NW} Amazonas, maybe Amapá), S Venezuela.

\section{Pouteria Aublet}

Leaves usually spirally arranged, rarely opposite, venation never finely striate, no stipules. Inflorescences axillary or ramiflorous, fasciculate, fascicles single or sometimes arranged along short leafless shoots; flowers often unisexual, calyx with a single whorl of 4-6 free, imbricate or quincuncial sepals, or with 6-11 sepals in a closely imbricate spiral. Fruit a berry with 1-several seeds; seeds broadly ellipsoid, plano-convex, shaped like the segment of an orange, or laterally compressed, testa smooth, wrinkled, or pitted, scar adaxial, usually extending the full length of the seed, narrow, broad or sometimes covering almost all the seed surface.

Notes. Trees or shrubs, pantropical, with 188 species throughout the Neotropics.

\section{Pouteria section 1. Franchetella (Pierre) Eyma}

Leaves with higher order venation often finely areolate, usually conspicuous, lower surface not usually glaucous. Calyx 4-5-merous. Seed laterally compressed or not, scar adaxial, rarely extending around the base, broad or narrow.

Pouteria anomala (Pires) Pennington abiú-rosadinha, abiurana-roxa (B) Pl. 13, fig. 5

Leaves loosely clustered, chartaceous, glabrous, with 15-20 pairs of secondary veins. Fascicles axillary and below the leaves, 2-7-flowered, sepals $5,0.2-0.25 \mathrm{~cm}$ long, rounded, in fruit $0.3 \times 0.2 \mathrm{~cm}$; pedicels $0.3-0.6 \mathrm{~cm}$, in fruit $0.9-1.0 \mathrm{~cm}$ long, $1-$ 2 together on $0.2 \mathrm{~cm}$ long and $0.3 \mathrm{~cm}$ wide protuberances. Fruit globose or ellipsoid, $1.6 \times 1.3$ to $2.8(-3) \times 2.6 \mathrm{~cm}$, rounded at base and apex, apex with 0.1 $\mathrm{cm}$ long prickle, maturing yellow or red, epicarp thin coriaceous, smooth, glabrous, fruit weighing 55 grams $(n=50)$; seeds 1 , broadly ellipsoid, $1.2 \times 0.8$ to $2 \times 1.4 \times 1.1 \mathrm{~cm}$, base and apex rounded or obtuse, testa shining, dark brown above, light brown toward scar, scar 1.8 x $0.9 \mathrm{~cm}$, dull brown, finely wrinkled, with a median vertical furrow.

Notes. Tree to $35 \mathrm{~m}$ high and 110 $\mathrm{cm}$ diam., slash exuding white latex; north of Manaus, Amazonas, Brazil, black bearded sakis (Chiropotes satanas chiropotes) (Frazão, 1992) and golden-faced sakis (Pithecia pithecia chrysocephala) (Setz, 1993) were seen predating on the immature seeds, but also eating the mature pulp and dropping the mature seeds, whereas in the R. Urucú region, C Amazonas, Peres saw brown capuchins and Geoffroy's woolly monkeys (Lagothrix lagotricha cana) (Peres, 1994) feeding on the mature pulp, swallowing and dispersing the seeds, and Pionites parrots eating only the ripe pulp; lowland terrafirme rainforest up to $300 \mathrm{~m}$ altitude.

Distribution. Brazil (Amazonas, Pará), S Venezuela.

\section{Pouteria atabapoensis (Aubréville)}

Pennington Pl. 13, fig. 6

Leaves spaced, coriaceous, sparsely appressed puberulous below, with $10-13$ pairs of secondary veins. 
Fascicles axillary, 5-15-flowered, sepals 4, suborbicular, ca. $0.2 \mathrm{~cm}$ long; pedicels ca. $0.2 \mathrm{~cm}$ long, sparsely appressed puberulous, in fruit to $0.3 \mathrm{~cm}$ long. Fruit broadly ellipsoid, to $3.5 \mathrm{x}$ $2.8 \mathrm{~cm}$, rounded at base and apex, apex with prickle, epicarp thin and soft, at first green, maturing yellow to black, smooth, glabrous, pulp fleshy; seeds 1 , broadly ellipsoid, slightly laterally compressed, to $3 \times 2.3 \times 2 \mathrm{~cm}$, testa light brown, rather shining, smooth, scar adaxial and basal, to 2.9 $x$ 0.7-1 cm, dull brown.

Notes. Tree to $7(-20) \mathrm{m}$ and $15-$ $40 \mathrm{~cm}$ diam., slash exuding milky latex; fruit and/or immature seed is a probable food item for Spix's blackheaded uacaries (Cacajao melanocephalus ouakary); black water flooded forest (igapó) on sandy river margins.

Distribution. Brazil $(\mathrm{C}+\mathrm{W}$ Amazonas), S Venezuela.

\section{Pouteria aubrevillei Bernardi} abiurana (B) PI. 14, fig. 1

Leaves spaced or loosely clustered, coriaceous, glabrous, with 10-15 pairs of secondary veins. Fascicles borne below the leaves, 10-20-flowered, flowers unisexual, sepals $5,0.1$ $0.15 \mathrm{~cm}$ long; pedicels $0.2-1.0 \mathrm{~cm}$ long, sparsely appressed puberulous. Fruit ellipsoid, $2.5-3.5 \mathrm{~cm}$ long, slightly asymmetrical, apex acute to obtuse, base acute or tapering to a ca. $0.5 \mathrm{~cm}$ long stipe, maturing green, epicarp thin, soft, smooth, glabrous; seeds 1, ellipsoid, 2-2.7 cm long, testa smooth, adhering to the pulp, scar adaxial, the length of the seed, 0.4-0.7 $\mathrm{cm}$ wide.
Notes. Tree to $30 \mathrm{~m}$ high and 40 $\mathrm{cm}$ diam., without buttresses, bark reddish, scaling, slash exuding copious white latex; lowland terra-firme rainforest.

Distribution. Brazil Amazonas), Fr. Guiana, Am. Peru.

Pouteria bangii (Rusby) Pennington abiú rosadinha (B); pepeboiti (P)

\section{Pl. 14, fig. 2}

Leaves spaced, subcoriaceous, (pale) golden appressed puberulous below, with 7-14 pairs of secondary veins. Fascicles axillary and on older twigs, 5-20-flowered, flowers unisexual, sepals $4,0.15-0.2 \mathrm{~cm}$ long; pedicels $0.3-1.0 \mathrm{~cm}$, in fruit $0.7-1.5 \mathrm{~cm}$ long. Fruit (oblong) ellipsoid, $2.5 \times 1.5$ to $3 \times 1.7 \mathrm{~cm}$, sometimes up to $5.6 \mathrm{~cm}$ long, apex acute to rostrate over 0.2$0.4 \mathrm{~cm}$, with prickle and often a circular $0.5 \mathrm{~cm}$ diam. patch, base acute to rounded, maturing (olive-)green to orange, epicarp hard, thick, smooth, glabrous or somewhat appressed puberulous; seeds 1 , ellipsoid, slightly laterally compressed, $1.5 \times 1.1 \times 0.9$ to $2(-3) \times 1.3 \times 0.9 \mathrm{~cm}$, apex and base rounded, testa smooth, veined or slightly wrinkled, shining, scar the length of the seed or slightly less, 0.2 $0.3 \mathrm{~cm}$ wide.

Notes. Tree to $30 \mathrm{~m}$ high and 40 $\mathrm{cm}$ diam., bark (whitish-)grey, finely vertically cracked, slash pink, exuding white latex; Humboldt's woolly monkeys (Lagothrix lagotricha lagotricha) at the Lower Río Apaporis, Am. Colombia, are reported to feed on the mature pulp, dispersing the seeds endochorically (Defler, pers. comm.); terra-firme rain and savanna forest, 


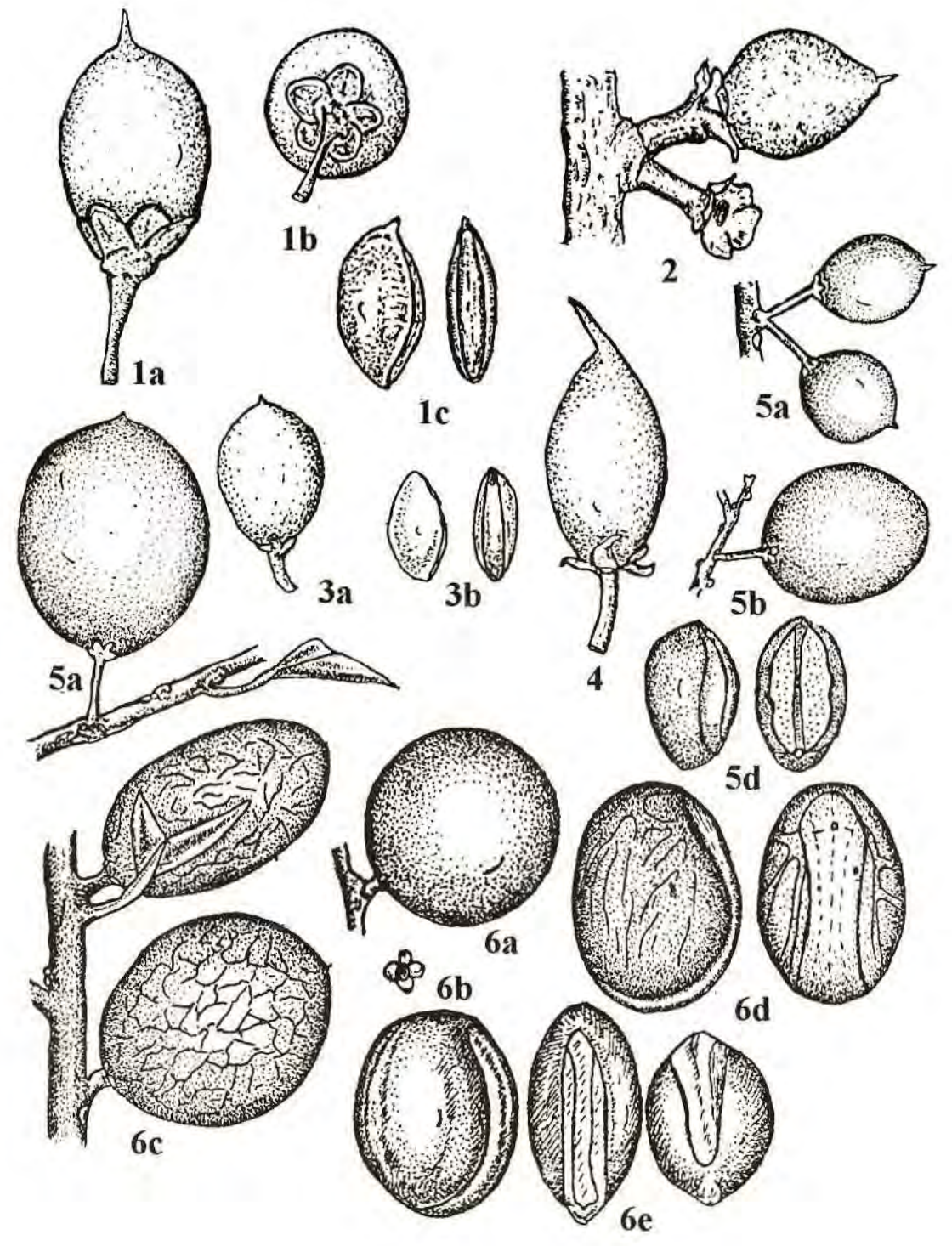

PI. 13. Figs. 1-6. SAPOTACEAE. 1. Micropholis caudata, a. fruit; b. fruit from below; c. seed, lateral and frontal view (Peres 589, 612, 654). 2, M. cayennensis, fruit (Billiet \& Jadin 1231). 3. M. obscura, a. fruit; b. seed, lateral and frontal view (Peres 392, 617, 693, 734; Van Roosmalen 107). 4. M. splendens, fruit (Clark 7094). 5. Pouteria anomala, a. young fruits; $b$, c. fruit; d. seed, lateral and frontal view (Van Roosmalen 109; Peres 345, 787). 6. P. atabapoensis, a. fruit; b. fruiting calyx; c. infructescence; d, e. seed, lateral, frontal view and basal view (Van Roosmalen 184). 
also found in xeromorphic forest on slopes, at 100-1,200 m altitude.

Distribution. Am. Bolivia, Brazil (Acre, Amapá, Pará), E Colombia, Guianas, Am. Peru.

Pouteria benai (Aubréville \&

Pellegrin) Pennington

pepeboiti (P)

Leaves loosely clustered, chartaceous, glabrous, with 7-8 pairs of secondary veins. Fascicles axillary and below the leaves, 2-3-flowered, sepals 5 , suborbicular, $0.25-0.35 \mathrm{~cm}$ long, brown pubescent; pedicels slender, 1.8-2(-3) $\mathrm{cm}$ long. Fruit has not been collected yet.

Notes. Tree to $20 \mathrm{~m}$ high; lowland terra firme rainforest.

Distribution. Fr. Guiana.

Pouteria bilocularis (Winkler) Baehni 14, fig. 3

moraballi (A); abiurana (B) PI.

Leaves spaced, coriaceous, glabrous, minutely punctate below, with 7-11 pairs of secondary veins. Fascicles axillary and in the axils of fallen leaves, 220-flowered, flowers uni- and bisexual, sepals 4-5, 0.1-0.15 cm long; pedicels 0.2 $0.6 \mathrm{~cm}$ long, appressed puberulous or glabrous. Fruit ellipsoid or obovoid, $2.5-6 \mathrm{~cm}$ long, apex rounded, base acute to obtuse or rounded, epicarp hard, maturing orangeyellow, smooth, glabrous; seeds 1, ellipsoid, 2-3.5 cm long, laterally compressed, apex and base rounded, testa shining, wrinkled or verrucose, scar the length of the seed, adaxial, $0.2-0.4 \mathrm{~cm}$ wide.

Notes. Tree to $35 \mathrm{~m}$ high and 40 $\mathrm{cm}$ diam., with to $2 \mathrm{~m}$ high buttresses, slash exuding copious white latex; the mature fruits are reported to be eaten by brown capuchin monkeys (Cebus apella) in Peru (Janson, pers, comm.); lowland rainforest over sand or clay, sometimes on periodically flooded land, from sea level up to $1,200 \mathrm{~m}$ altitude.

Distribution. Am. Bolivia, Brazil (Acre, Amazonas, Pará, Rondônia, Roraima), Am. Colombia, Fr. Guiana, Guyana, Am. Peru, Am. Venezuela.

\section{Pouteria campanulata Baehni}

Leaves spaced or loosely clustered, coriaceous, appressed puberulous below, glabrescent, with 14-23 pairs of secondary veins. Fascicles axillary and on old wood on cushion-like protuberances, 5-manyflowered, sepals $5,0.25-0.3 \mathrm{~cm}$ long, puberulous; pedicels $0.5-1.5 \mathrm{~cm}$ long, puberulous. Fruit ellipsoid, $1.5-1.7 \mathrm{~cm}$ long, apex acute, base rounded, smooth or finely lenticellate, glabrous; seeds 1, ellipsoid, ca. $1.3 \mathrm{~cm}$ long, not laterally compressed, apex and base obtuse, testa smooth, shining, scar adaxial, the length of the seed, ca. $0.15 \mathrm{~cm}$ wide.

Notes. Tree to $27 \mathrm{~m}$ high and 30 $\mathrm{cm}$ diam., without buttresses, bark reddish, slash with copious sticky white latex; rain and savanna forest on nonflooded land to $700 \mathrm{~m}$ altitude. Pará).

Distribution. Brazil (Amazonas,

\section{Pouteria cladantha Sandwith}

aiomorokushi (A); pinto-boletri (S); abiurana-seca, caramuri -preto (B) Pl. 14, Fig. 4

Leaves spaced, thinly coriaceous, glabrous, minutely punctate below, with 9-15 pairs of secondary veins. Fascicles axillary or on up to 8 $\mathrm{cm}$ long leafless axillary shoots, fruiting sepals 4-5, inner ones $0.1-0.15 \mathrm{~cm}$, 
outer ones $0.25-0.4 \mathrm{~cm}$ long, free or fused at base, minutely appressed puberulous; fruiting pedicels $0.3-0.6 \mathrm{~cm}$ long, appressed puberulous. Fruit ellipsoid to globose, $2.4-3 \times 2.0-2.6 \mathrm{~cm}$, rounded at apex and base, epicarp thinly coriaceous, maturing yellow, smooth, at first ferruginous-puberulous, glabrous when mature, pulp fleshy, transparent; seeds 1 , ellipsoid, slightly laterally compressed, $1.6 \times 1.4 \times 1.2 \mathrm{~cm}$ up to $2.2 \mathrm{~cm}$ long, base and apex rounded, testa smooth, light brown, shining, scar adaxial, the length of the seed, 0.3-0.4($0.7) \mathrm{cm}$ wide, dull.

Notes. Tree to $30 \mathrm{~m}$ high and 80 $\mathrm{cm}$ diam., larger trees with up to $2 \mathrm{~m}$ high buttresses and deeply fluted bole, slash exuding sticky white latex; immature seeds were seen predated upon by primates (Pithecia albicans) in the R. Urucú region, Amazonas, Brazil (Peres, pers. comm.); lowland rain and savanna forest on non-flooded land up to $800 \mathrm{~m}$ altitude.

Distribution. Am. Brazil (Acre, Amapá, Amazonas, Pará, Roraima), Am. Colombia, Guianas, Am. Peru, Am. Venezuela.

\section{Pouteria coriacea (Pierre) Pierre} fig. 5

kudibuschi, moraballi (A) PI. 14,

Leaves spaced, chartaceous, glabrous, with 7-10 pairs of secondary veins. Fascicles axillary and in the axils of fallen leaves, sometimes clustered on short axillary shoots, 3-10flowered, flowers bisexual, sepals 4 , 0.1-0.15 cm long; pedicels $0.3-0.7 \mathrm{~cm}$, in fruit $0.9-1.5 \mathrm{~cm}$ long, slender, Fruit ellipsoid or ovoid, 2.1-2.4 x 1.3-1.7 $\mathrm{cm}$, sometimes up to $4 \mathrm{~cm}$ long, apex acute or attenuate over $0.1-0.4 \mathrm{~cm}$, with prickle, base acute to rounded, green to orange-yellow, epicarp hard, smooth, glabrous; seeds 1, ellipsoid, $1.4 \times 0.8 \mathrm{~cm}$, sometimes up to $2.4 \mathrm{~cm}$ long, slightly laterally compressed, base and apex rounded or obtuse, testa shining, strongly transversely wrinkled, scar extending sometimes around the base, $0.2-0.3 \mathrm{~cm}$ wide.

Notes. Tree to $30 \mathrm{~m}$ high and 40 $\mathrm{cm}$ diam., bole cylindrical, bark reddish-brown, shallowly fissured, slash exuding sticky white latex; rain and savanna forest on non-flooded land to $700 \mathrm{~m}$ altitude.

Distribution. Am. Brazil (Amapá, N Amazonas, Pará), Am. Colombia, Guianas, Venezuela.

Pouteria crassiflora Pires \& Pennington

Leaves loosely clustered, thinly coriaceous, puberulous below, with 16-25 pairs of secondary veins. Fascicles axillary and below the leaves, 3 10-flowered, flowers bisexual, sepals $5(-6), 0.5 \mathrm{~cm}$ long, puberulous; pedicels $0.2-0.5 \mathrm{~cm}$ long, tomentose. Fruit densely tomentose when young, maturing orange.

Notes. Tree to $20 \mathrm{~m}$ high and 35 cm diam., bark thinly flaking; lowland terra-firme rainforest.

Distribution. Brazil (Amapá).

\section{Pouteria durlandii (Standley)}

\section{Baehni subsp. durlandii} asipokoballi (A) Pl. 14, fig. 6

Leaves chartaceous to thinly coriaceous, glabrous, with 7-14 pairs of secondary veins. Fascicles axillary and below the leaves, 1-3(-6)-flowered, 
flowers unisexual, sepals (4-)5, 0.2-0.5 cm long; pedicels $0.1-0.3(-0.5) \mathrm{cm}$ long, puberulous. Fruit ellipsoid to subglobose, $2-2.5 \mathrm{~cm}$ long, apex rounded to acute or shortly apiculate, base rounded or truncate, maturing yellow to orange, smooth, glabrous; seeds 1-2, ellipsoid, sometimes slightly laterally compressed, planoconvex when 2-seeded, 1.6-2.1 cm long, testa smooth, free from sweet-tasting pulp, scar usually very broad, covering about onethird of the seed surface $(0.35 \mathrm{~cm}$ wide) .

Notes. Tree to $25 \mathrm{~m}$ high and 65 $\mathrm{cm}$ diam., already flowering and fruiting when only $5-10 \mathrm{~m}$ high, later with to $2 \mathrm{~m}$ high buttresses, bole sometimes fluted, bark grey- to reddish-brown, scaling in small, thin strips, slash pink, soft, exuding white latex; wet lowland rainforest and wet coastal forest.

Distribution. Bolivia, Brazil (Amapá?, Atlantic forest), Colombia, Guyana, Am. Peru.

\section{Pouteria egregia Sandwith}

kokoritiballi (A); kleinbladig zwart riemhout (SD); alofachiboiti (P); cururu (B) Pl. 15, fig. 1

Leaves spaced, spirally arranged to subopposite, chartaceous to subcoriaceous, greyish-green to glaucous below, puberulous or glabrous, with 14-21 pairs of secondary veins. Fascicles axillary and below the leaves, 5 15-flowered, flowers unisexual, sepals 4 , fused to about halfway, ca. $0.1 \mathrm{~cm}$ long, brown-sericeous; pedicels 0.2 $0.4(-0.8) \mathrm{cm}$ long, brown-sericeous. Fruit broadly ellipsoid to globose, 1.8$2.7 \mathrm{~cm}$ long, apex rounded or obtuse, base rounded to slightly tapered, maturing yellow to dull orange, smooth or minutely verruculose, glabrous; seeds $1(-2)$, broadly ellipsoid to obovoid, 1.4$1.8 \mathrm{~cm}$ long, slightly laterally compressed, rounded at base and apex, testa smooth, shining, scar extending the full length of the seed, $0.35-0.8 \mathrm{~cm}$ wide.

Notes. Tree to $40 \mathrm{~m}$ high and 90 $\mathrm{cm}$ diam., with to $2.5 \mathrm{~m}$ high, simple or branched buttresses, bole cylindric, slightly fluted at base, bark pale buffor grey-brown, vertically cracked and scaling in thin narrow strips, slash orange-streaked, exuding copious sticky white latex; lowland terra-firme rainforest to $800 \mathrm{~m}$ altitude.

Distribution. Brazil (Pará), Am. Colombia, Guianas, Venezuela.

\section{Pouteria engleri Eyma}

konoko, halchiballi (A); grootbladig zwart riemhout (SD); mamanten, lo-oedoe (S); abiú, abiurana (B) Pl. 15, fig. 2

Leaves chartaceous, glabrous, with 6-9 pairs of secondary veins. Fascicles axillary and below the leaves, 10-20-flowered, flowers bisexual, sepals 5 , ovate or oblong, 0.2 $0.25 \mathrm{~cm}$ long, puberulous to grey-sericeous; pedicels $0.4-0.8 \mathrm{~cm}$ long, in fruit $0.9-1.1 \mathrm{~cm}$ long, puberulous. Fruit ellipsoid to subglobose, 2-2.5($3.3) \times 1.5(-2.9) \mathrm{cm}$, apex and base rounded, apex with a sunken prickle, epicarp chartaceous, pulp thick, fleshy and sweet-tasting, lightgreen to yellow, maturing orange-yellow, shining, smooth, glabrous; seeds 1, ellipsoid, slightly laterally compressed, 1.8-2.1 $\mathrm{x} 1.1 \mathrm{~cm}$, apex acuminate, base rounded, testa slightly wrinkled, brown, shining, scar extending the full length of the seed, dull, lightbrown, $0.2-0.7 \mathrm{~cm}$ wide, with $0.1 \mathrm{~cm}$ wide, 


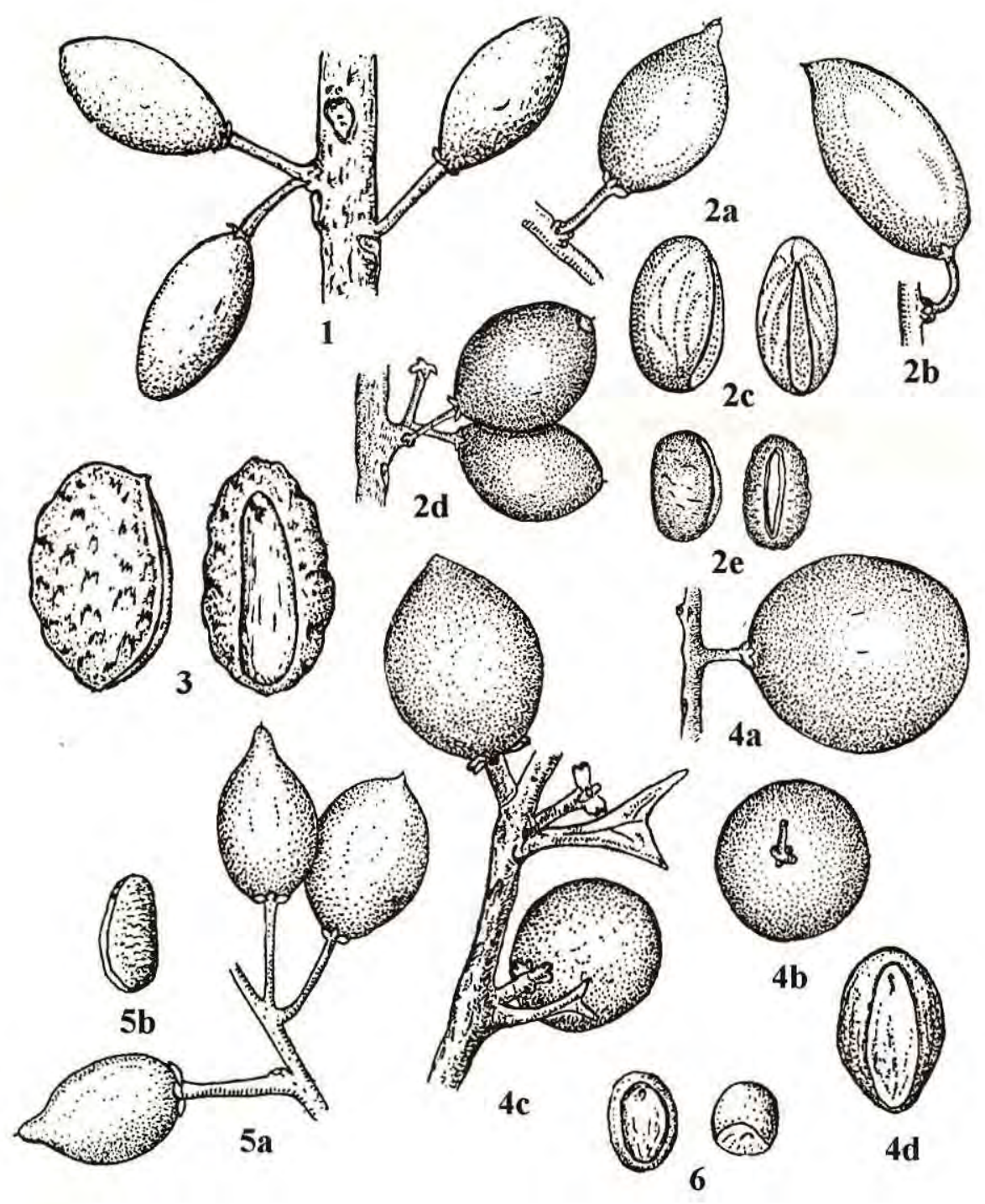

PI. 14. Figs. 1-6. SAPOTACEAE. 1. Pouteria aubrevillei, infructescence (Rimachi 3098). 2. P. bangii, a, b. fruit from Suriname; c. seed from Suriname, lateral and frontal view; $d$. fruits from Brazil; e. seed from Brazil, lateral and frontal view (Defler 101). 3. P. bilocularis, seed lateral and frontal view (Davidse \& Huber 15370). 4. P. cladantha, a. fruit; b. fruit from below; c. infructescence; d. seed, frontal view (Peres 678). 5. P. coriacea, a. infructescence; b. seed, lateral view (Maas 10804; Schultes \& Cabrera 12553). 6. P. durlandii subsp. durlandii, seed seen from aside and above (Lundell 12262). 
yellow margin.

Notes. Tree to $38 \mathrm{~m}$ high and $1 \mathrm{~m}$ diam., with simple, to $2 \mathrm{~m}$ high buttresses and cylindrical bole, bark reddish- to greyish-brown, rough and flaking, slash orange to pinkish, exuding sticky white latex; the mature pulp was seen eaten by red-faced black spider monkeys (Ateles paniscus) (dispersing the seeds endochorically) and golden-faced sakis (Pithecia pithecia chrysocephala) (spitting out the seeds) in the forests north of Manaus, Brazilian Amazon (Setz, 1993); terra-firme rain and savanna forest, $200-800 \mathrm{~m}$ altitude.

Distribution. Brazil (Amapá, Amazonas, Pará), Guianas.

\section{Pouteria fulva Pennington}

Leaves spaced, coriaceous, densely appressed golden-ferruginous puberulous below, with 8-11 pairs of secondary veins. Fascicles borne below the leaves, 5-10-flowered, sepals 5, ca. $0.2 \times 0.3 \mathrm{~cm}$, appressed puberulous; pedicels $1.3-1.5 \mathrm{~cm}$ long, appressed puberulous. Fruit not yet collected.

Notes. Tree to $25 \mathrm{~m}$ high and 25 $\mathrm{cm}$ diam.; terra-firme lowland rainforest.

Distribution. Brazil Amazonas, only collected twice).

\section{Pouteria gonggrijpii Eyma}

kokoritiballi (A); apra-oedoe, pinto-boletri (S); akwansiba (P); abiú

\section{(B) PI. 15, fig. 3}

Leaves spaced, thinly coriaceous, appressed puberulous below, with 8-13 pairs of secondary veins. Fascicles axillary and in the axils of fallen leaves, 5-20-flowered, flowers uni- and bisexual, sepals 5 , ovate,
0.15-0.2 cm long, appressed puberulous; pedicels $0.2-0.7 \mathrm{~cm}$ long, brown appressed puberulous, in fruit to $1.3 \mathrm{~cm}$ long. Fruit ellipsoid, $1.7 \mathrm{x}$ $1.5 \mathrm{~cm}$ to $3-3.3 \times 2 \mathrm{~cm}$, apex rounded, base often tapering to a short stipe, green to orange, smooth, subglabrous; seeds 1 , oblong, $2-2.2 \times 0.8-1 \mathrm{~cm}$, rounded at both ends, not laterally compressed, testa smooth, adherent to the pulp, scar extending the full length of the seed, ca. $0.4 \mathrm{~cm}$ wide, very rough and warty.

Notes. Tree to $28 \mathrm{~m}$ high and 40 $\mathrm{cm}$ diam., with small buttresses and cylindrical bole, bark reddish-brown, scaling in thin pieces, slash orange or red, exuding copious sticky white latex; lowland terra-firme savanna and rain forest, especially on slopes to 600 $\mathrm{m}$ altitude.

Distribution. N Brazil (Amapá, Amazonas, Pará), Fr. Guiana, Suriname, Venezuela.

Pouteria jariensis Pires \& Pennington abiú, guajará (B) PI. 15, fig. 4

Leaves coriaceous, glabrous, with 714 pairs of secondary veins. Fascicles axillary and below the leaves, 2-5-flowered, sepals $5,0.25 \mathrm{~cm}$ long, appressed puberulous; pedicels $0.15-0.2 \mathrm{~cm}$ long, appressed puberulous. Fruit ellipsoid to obovoid, $2.5-3 \mathrm{~cm}$ long, apex rounded or obtuse, base obtuse, maturing yellow to orange, smooth, velutinous; seeds 1-2, ellipsoid to obovoid (plano-convex when 2seeded), $1.5 \times 0.8-1 \mathrm{~cm}$, apex rounded, base acute, testa smooth, adherent to pulp, scar extending the full length of the seed, elliptic, $0.45-0.7 \mathrm{~cm}$ wide. 
Notes. Tree to $26 \mathrm{~m}$ high and 40 $\mathrm{cm}$ diam., with steep, simple, up to 1.5 $\mathrm{m}$ high buttresses and fluted bole, bark greyish to brown, scaling in thin, slender pieces, slash pink, exuding sticky white latex; lowland terra-firme rain and savanna forest, and secondary forest, at $200-650 \mathrm{~m}$ altitude.

Distribution. Brazil (Amapá, Pará, Rondônia), Fr. Guiana.

\section{Pouteria lucumifolia (Reissik ex}

Maximowicz) Pennington coquiranazinha (B) PI. 15, fig. 5

Leaves spaced, coriaceous, glabrous, with 8-14 pairs of secondary veins. Fascicles axillary and in the axils of fallen leaves, 2-10-flowered, flowers unisexual, sepals $4-5$, broadly ovate, 0.1-0.15 cm long; pedicels 0.2$0.6 \mathrm{~cm}$, in fruit to $1 \mathrm{~cm}$ long. Fruit (oblong-)ellipsoid, $2-3 \times 1.5-1.7 \mathrm{~cm}$, apex obtuse to rounded, base tapered, sometimes forming a short stipe, maturing yellow to orange, epicarp hard, smooth, glabrous; seeds 1, ellipsoid, $1.5-2.1 \mathrm{~cm}$ long, laterally compressed, rounded at both ends, testa rough, wrinkled and finely transversely fissured, adherent to the pulp, scar fulllength and extending around the base of the seed, 0.2-0.4 cm wide.

Notes. Tree to $30 \mathrm{~m}$ high and 50 $\mathrm{cm}$ diam., with a cylindrical bole and brown, fissured and scaling bark, slash exuding white latex; upland rainforest on white sand, in Venezuela found in periodically flooded forest (igapó) to $200 \mathrm{~m}$ altitude.

Distribution. Brazil

(W Amazonas), Am. Colombia, Am. Peru, Am. Venezuela.

\section{Pouteria melanopoda Eyma}

moraballi (A); riemhout (SD); blaka-jamboka (S); akwansiba (P) PI. 15, fig. 6

Leaves loosely spirally arranged, coriaceous to chartaceous, glabrous, with 11-13 pairs of secondary veins. Fascicles below the leaves, 2-5-flowered, sepals 5, acute-ovate, patent, 0.2$0.3 \mathrm{~cm}$ long, puberulous; petals often persistent in fruit; pedicels $0.4-0.5 \mathrm{~cm}$, in fruit ca. $0.9 \mathrm{~cm}$ long, slender, brown-puberulous; fruits solitary or in pairs. Fruit ellipsoid, immature ca. 1.5 $x 1.2 \mathrm{~cm}$, green, puberulous, apex with prickle, pulp white, transparent, sweettasting; seeds 1 (sometimes 2-5), ellipsoid, slightly laterally compressed, to $1.4 \times 0.9 \times 0.7 \mathrm{~cm}$, testa dark brown, scar extending the length of the seed, $0.4 \mathrm{~cm}$ wide, white.

Notes. Tree to $36 \mathrm{~m}$ high and 70 cm diam., with simple or branched, steep and slightly concave, to $2.5 \mathrm{~m}$ high buttresses, bole cylindrical, bark reddish-brown, scaling in small thin rectangular pieces, slash cream with pink, exuding sticky white latex; hill forest up to $400 \mathrm{~m}$ altitude.

Distribution. Fr. Guiana, Suriname.

\section{Pouteria minima Pennington}

Leaves broad obovate, rounded, coriaceous, glabrous, slightly glaucous below, with 8-9 pairs of secondary veins. Fascicles axillary and below the leaves, 10-60-flowered; flowers unisexual, minute, sepals 5 , ca. $0.1 \mathrm{~cm}$ long, appressed puberulous; pedicels 0.2-0.3 cm long, appressed 
puberulous. Fruit when immature ellipsoid, ca. $2.4 \mathrm{~cm}$ long, apex rounded, base obtuse, smooth, glabrous.

Notes. Large tree, known only from two collections; lowland rain forest.

Distribution. Brazil (NW Amazonas - R. Vaupés).

Pouteria nudipetala Pennington PI.

\section{5 , fig. 7}

Leaves oblanceolate, chartaceous, glabrous, with 12-20 pairs of secondary veins. Fascicles mostly below the leaves at defoliated nodes, 2-3-flowered, flowers unisexual, sepals $5,0.2 \mathrm{~cm}$ long, densely long-hispid outside; pedicels $0.2-0.3 \mathrm{~cm}$ long, densely hispid. Fruit ellipsoid or obovoid, $2.5-3 \times 1.3-1.5 \mathrm{~cm}$, apex rounded, base acute to rounded, smooth, densely hispid, apex with persistent style; seeds 1 , laterally compressed, testa smooth, free from pulp, scar $0.15 \mathrm{~cm}$ wide.

Notes. Tree to $10 \mathrm{~m}$ high, slash exuding white sticky latex; few collections from periodically white-water flooded forest (várzea), in Peru also found in upland rain forest.

Distribution. Brazil

(W Amazonas), Peru.

\section{Pouteria pachyphylla Pennington} abiurana (B) Pl. 15, fig. 8

Leaves coriaceous, glabrous, with 12-15 pairs of secondary veins. Fascicles axillary, 5-10-flowered, sepals 5, suborbicular, ca. $0.1 \mathrm{~cm}$ long; pedicels $0.1 \mathrm{~cm}$ long. Fruit narrowly obovoid to ellipsoid, 1.7-2.1 x 1-1.3 cm, apex and base acute to obtuse, maturing black, smooth, glabrous; seeds 1, narrowly ellipsoid, $1.4-1.8 \times 0.7-1 \mathrm{~cm}$, not laterally compressed, apex and base acute to obtuse, testa smooth, shining, scar extending the full length of the seed, 0.25-0.4 $\mathrm{cm}$ wide.

Notes. Tree to $20 \mathrm{~m}$ high and 20 $\mathrm{cm}$ diam.; periodically flooded river margins and permanently black-water flooded forest (igapó).

Distribution. Brazil (Amazonas, Rondônia).

Pouteria platyphylla (A.C. Smith) Baehni

abiurana-vermelha, abiuranajacaré (B) Pl. 15, fig. 9

Leaves loosely clustered, chartaceous to thinly coriaceous, large, strongly bullate, finely golden-brown pubescent below, with 9-13(-16) pairs of secondary veins. Fascicles borne below the leaves, 2-10-flowered, flowers unisexual, sepals $5,0.2(-0.4) \mathrm{cm}$ long, united at base, tomentose; pedicels 0.6$1.3(-2) \mathrm{cm}$ long, tomentose. Fruit (depressed) globose, to $3.6 \times 4 \mathrm{~cm}$, apex and base rounded to truncate, base obscurely 5-10 times striate, apex with irregular light-brown $1.8-2.3 \mathrm{~cm}$ diam. patch, epicarp thick-coriaceous to corky, $0.6 \mathrm{~cm}$ thick, with golden-brown indumentum; seeds 1-2, ellipsoid, 1.8$2 \times 1.2 \times 1.1 \mathrm{~cm}$, shining, light brown, scar dull, extending the full length of the seed, $0.2-0.3 \mathrm{~cm}$ wide.

Notes. Tree to $18 \mathrm{~m}$ high and 25 cm diam., with reddish scaly bark, slash exuding white sticky latex; the immature seeds were seen predated by black bearded sakis (Chiropotes satanas chiropotes) $80 \mathrm{~km}$ north of Manaus, Amazonas (Frazão, 1992); lowland terra-firme rain forest. 


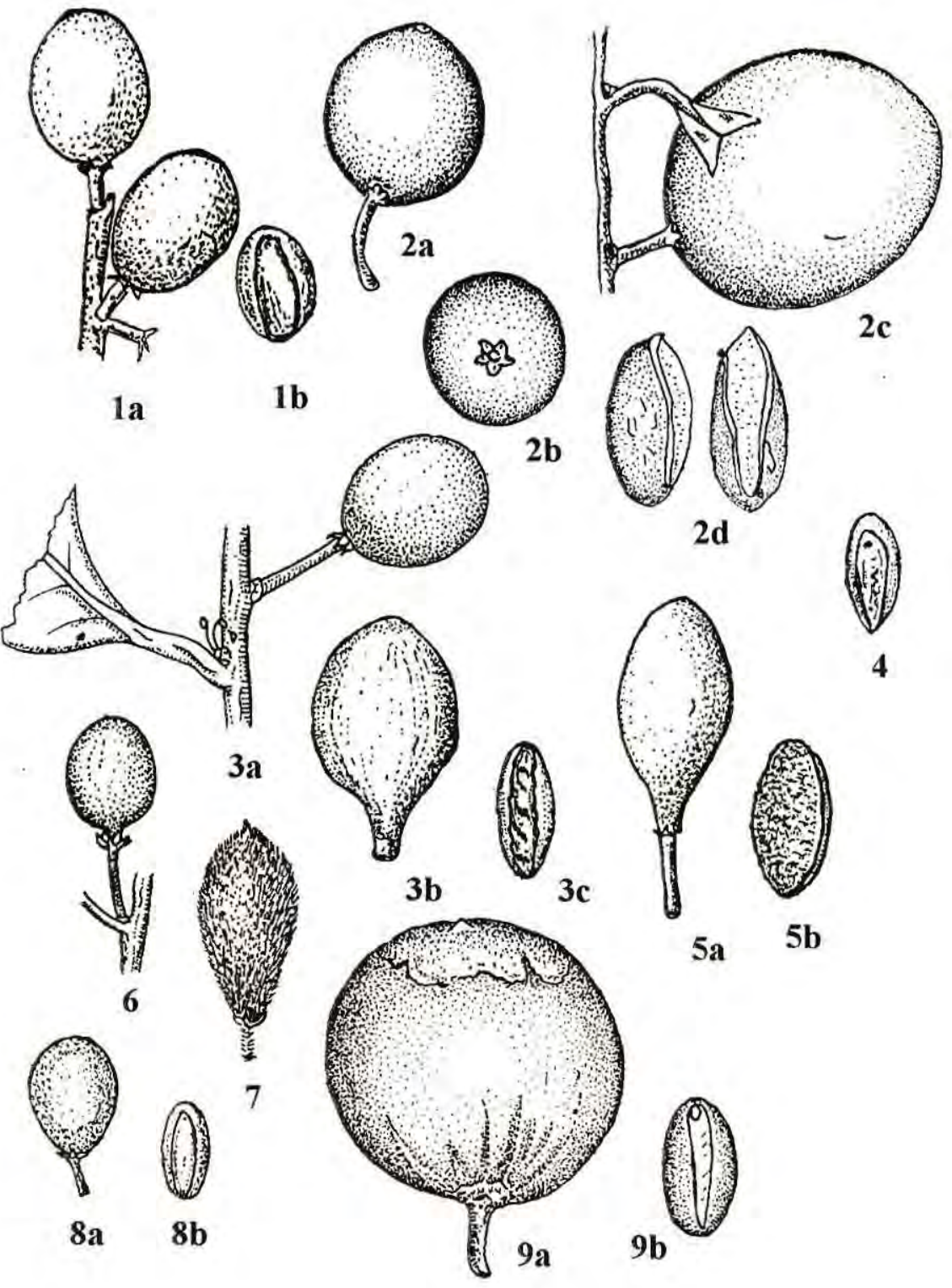

PI. 15. Figs. 1-9. SAPOTACEAE. 1. Pouteria egregia, a. infructescence; b. seed, frontal view (Blanco 582). 2. P. engleri, a. young fruit; b. young fruit from below; c. mature fruit; d. seed, lateral and frontal view (Van Roosmalen 122). 3. P. gonggrijpii, a. fruit; b. fruit with stipe; $\mathrm{c}$. seed, frontal view (Oldeman 3298). 4. P. jariensis, seed, frontal view (Silva 122). 5. P. lucumifolia, a. fruit; b. seed (Liesner 8864). 6. P. melanopoda, young fruit (Van Roosmalen 634). 7. P. nudipetala, fruit (Krukoff 5201). 8. P. pachyphylla, a. fruit; b. seed, frontal view (Prance et al. 4763). 9. P. platyphylla, a. fruit; b. seed, frontal view (Frazão 214). 
Distribution. Brazil (Amazonas, Mato Grosso), Peru.

Pouteria pubescens (Aubréville \& Pellegrin) Pennington Pl. 16, fig. 1

Leaves spaced, coriaceous, densely brown-puberulous below, with 10-12 pairs of secondary veins. Fascicles axillary, 10-15-flowered, sepals $5,0.1-0.15 \mathrm{~cm}$ (in fruit to $0.3 \mathrm{~cm}$ ) long, appressed puberulous; pedicels ca. $0.2 \mathrm{~cm}$ long, in fruit $1.5-1.8(-2) \mathrm{cm}$ long, puberulous. Fruit obliquely ellipsoid (one side convex, the other straight), $1.8 \times 1.3 \times 1.1 \mathrm{~cm}$ to $2.6 \times$ $1.6 \times 1.6 \mathrm{~cm}$, apex acuminate with oblique prickle, base obtuse or rounded, smooth, brown-sericeous; seeds 1, ellipsoid, laterally compressed, $1.7 \times 1.1 \times 0.8 \mathrm{~cm}$, adaxial surface strongly convex, abaxial surface straight, testa brown, shining, finely transversely striate, scar dull, 0.2-0.5 cm wide.

Notes. Tree to $20 \mathrm{~m}$ high and 25 $\mathrm{cm}$ diam.; only two collections known from terra-firme rain forest.

\section{Distribution. Brazil}

(W Amazonas), Am. Peru.

\section{Pouteria putamen-ovi Pennington Pl. 16, fig. 2}

Leaves coriaceous, subglaucous below, with 7-10 pairs of secondary veins. Fascicles in the axils of fallen leaves, 1-2-flowered, flowers sessile, sepals $5,0.5 \mathrm{~cm}$ long, subglabrous. Fruit globose or obovoid, 3.5-5.5 x 3$4 \mathrm{~cm}$, apex and base rounded, base sometimes slightly tapered, pale brown when dry, smooth, epicarp hard, 0.3-0.5 cm thick; seeds 1, ellipsoid, slightly laterally compressed,
2.4-3.4 cm long, apex and base obtuse or rounded, testa smooth, shining, scar extending the full length of the seed, $0.8-1.9 \mathrm{~cm}$ wide, only slightly narrower than the total width of the seed.

Notes. Tree to $20 \mathrm{~m}$ high and 75 $\mathrm{cm}$ diam.; terra-firme upland forest on sandy soil, 100-150 m altitude.

Distribution. Brazil (Rondônia), Peru (Loreto).

Pouteria ramiflora (Martius) Radlkofer abiú-do-campo (B) PI. 16, fig. 3

Leaves spaced, coriaceous to chartaceous, densely crisped-pubescent to glabrous, usually slightly glaucous below, with 8-16 pairs of secondary veins. Fascicles axillary and in the axils of fallen leaves or in axillary densely-flowered, to $2.5 \mathrm{~cm}$ long racemes, 5-15-flowered, flowers unisexual, sepals 4 , two $0.25 \times 0.3 \mathrm{~cm}$, two $0.2 \times 0.25 \mathrm{~cm}$, outside puberulous; pedicels $0.2-0.6 \mathrm{~cm}$ long, tomentose or puberulous, in fruit $0.9-1.1 \mathrm{~cm}$ long. Fruit plumlike, turbinate or broadly obovoid, $2.8 \times 2.3 \mathrm{~cm}$, less frequently ellipsoid, $3.6 \times 2.9 \mathrm{~cm}$, sometimes to $5 \mathrm{~cm}$ long, apex rounded or truncate, base tapered, epicarp coriaceous, $0.2 \mathrm{~cm}$ thick, blue-green to yellowish-brown, smooth, densely pubescent, glabrescent when mature, pulp fleshy, edible; seeds 1, ellipsoid, $2.5 \times 1.5 \times 1.0 \mathrm{~cm}$, sometimes to $3.2 \mathrm{~cm}$ long, laterally compressed, base and apex rounded, testa lightbrown, smooth, shining, scar extending around the base of the seed, $2.3 \times 0.3-$ $0.6 \mathrm{~cm}$, usually tapering from near the apex to base.

Notes. Tree to $10 \mathrm{~m}$ high, gnarled and with short trunk (in "cerrado"), or tree to $25 \mathrm{~m}$ high (in 
gallery forest), with reddish-brown, thick, corky, deeply fissured and cracked bark, slash exuding watery white latex; fruits reported to be eaten by toucans and araçaris, which disperse the seeds through regurgitation; in the central and southern part of its range ( $\mathrm{C}$ and $\mathrm{S}$ Brazil) found in rocky or sandy "cerrado" and gallery forest, in the northern part (Amazônia) it occurs in sandy "campo" islands' and white sand savanna, 200$1,300 \mathrm{~m}$ altitude.

Distribution. Brazil (Amazonas, Pará, Rondônia), Bolivia.

\section{Pouteria reticulata (Engler) Eyma} subsp. reticulata

abiú, abiurana-branca, abiuranacascuda, abiurana-folha-estreita (B)

\section{Pl. 16, fig. 4}

Leaves spaced, chartaceous to thinly coriaceous, glabrous, minutely punctate below, with 8-16 pairs of secondary veins. Fascicles axillary or in the axils of fallen leaves, sometimes clustered on leafless, 1-3 cm long axillary shoots, (1-)3-20-flowered, sepals 4-5 (-6), 0.1-0.2 cm long, free or partially united, outside appressed puberulous; pedicels $0.2-0.8(-1) \mathrm{cm}$, in fruit usually $0.5-0.7 \mathrm{~cm}$ long, appressed puberulous. Fruit ellipsoid or ovoid, 1.6-2.1 x 1.3-1.4 cm, sometimes to $4 \mathrm{~cm}$ long, apex acute to obtuse or rounded, base truncate, rounded or tapered, epicarp thinly coriaceous, maturing orange to red, smooth, glabrous, pulp fleshy; seeds 1 , ellipsoid, $1.4-1.7 \times 1.0 \times 0.8 \mathrm{~cm}$, to 2.5 $\mathrm{cm}$ long, usually slightly laterally compressed, apex and base obtuse, testa brown, smooth, shining, scar extending (almost) the full length of the seed, 0.2-0.4 (-1) cm wide, lightbrown, with a central longitudinal rib.

Notes. Tree to $40 \mathrm{~m}$ high and 50 $100 \mathrm{~cm}$ diam., with simple or sometimes branched, to $2 \mathrm{~m}$ high buttresses, bole frequently fluted, bark brown to pale greyish, scaling in large, thin, long plates, slash pale straw to reddish or orange; lowland terra-firme rain forest, on slopes, and occasionally in periodically white-water flooded forest (várzea).

Distribution. Am. Bolivia, Brazil (Amapá, Amazonas, Rondônia, Roraima), Am. Colombia, Guianas, Venezuela, Peru.

\section{Pouteria reticulata (Engler) Eyma}

subsp. surinamensis

asipokoballi, kokeritiballi (A)

Leaves spaced, chartaceous to thinly coriaceous, glabrous, minutely punctate below, with 8-16 pairs of secondary veins. Fascicles axillary or in the axils of fallen leaves, sometimes clustered on leafless, $1-3 \mathrm{~cm}$ long axillary shoots, (1-)3-20-flowered, sepals 4-5(-6), 0.1-0.2 cm long, free or partially united, outside with crisped indumentum; pedicels $0.15-0.2 \mathrm{~cm}$ long, with crisped indumentum. Fruit ellipsoid or ovoid, 1.6-4 cm long, apex acute to obtuse or rounded, base truncate, rounded or tapered, epicarp thinly coriaceous, maturing purple or black, smooth, glabrous, pulp fleshy; seeds 1 , ellipsoid, $1.4-2.5 \mathrm{~cm}$ long, usually slightly laterally compressed, apex and base obtuse, testa smooth, shining, scar extending (almost) the full length of the seed, $0.2-1 \mathrm{~cm}$ wide.

Notes. Tree to $30 \mathrm{~m}$ high and 50 $\mathrm{cm}$ diam., bole slightly fluted, bark scal- 
ing, slash exuding white sticky latex; rain and savanna forest to $250 \mathrm{~m}$ altitude.

Distribution. Brazil (Pará), Guyana, Suriname.

\section{Pouteria retinervis Pennington}

abiurana grande (B)

Leaves spaced, chartaceous, glabrous, with 11-14 pairs of secondary veins, the venation finely areolate on both surfaces. Fascicles axillary and in the axils of fallen leaves, 3-10-flowered, sepals 5 , ca. $0.2 \mathrm{~cm}$ long, appressed puberulous; pedicels 0.2-0.4 $\mathrm{cm}$ long, appressed puberulous. Fruit unknown.

Notes. Tree to $30 \mathrm{~m}$ high and 60 $\mathrm{cm}$ diam., with scaling bark, slash showing alternating bands of orange and white; "terra-firme" rain and savanna forest to $400 \mathrm{~m}$ altitude.

Distribution. Brazil (Amazonas), Fr. Guiana.

Pouteria rostrata (Huber) Baehni

abiurana (seringa)(B)

Leaves spaced, coriaceous, glabrous, often minutely punctate below, with 8-13 pairs of secondary veins. Fascicles axillary and in the axils of fallen leaves, 5-15-flowered, flowers unisexual, sepals $5,0.15 \mathrm{~cm}$ long, subglabrous; pedicels ca. $0.9 \mathrm{~cm}$ long. Fruit ellipsoid, ca. $2 \mathrm{~cm}$ long, apex and base rounded, epicarp thin, coriaceous, maturing pale orange, smooth, glabrous; seeds 1 , ellipsoid, ca. $1.6 \mathrm{~cm}$ long, slightly laterally compressed, apex and base obtuse, testa smooth, free from pulp, scar extending the full length of the seed, $0.15-0.2 \mathrm{~cm}$ wide.

Notes. Tree to $20 \mathrm{~m}$ high and
$60 \mathrm{~cm}$ diam., with short buttresses and fluted bole, bark dark colored, slash pink, exuding copious sticky white latex; periodically white-water flooded lowland forest (várzea) on sandy or clay soil, occasionally on terra-firme, at $150-350 \mathrm{~m}$ altitude.

Distribution. Brazil (Acre, Amazonas, Mato Grosso, Pará, Roraima), Am. Colombia, Am. Peru.

Pouteria sagotiana (Baillon) Eyma

achinadan, asusuchi (A); aproeoedoe, djoe-bortri (S) PI. 16, fig. 5

Leaves spaced, chartaceous, glabrous, with $10-12$ pairs of secondary veins. Fascicles axillary and in the axils of fallen leaves, 5-20-flowered, flowers unisexual, sepals 5 , partially fused, $0.1-0.15 \mathrm{~cm}$ long, appressed puberulous; pedicels $0.2-0.6 \mathrm{~cm}$ long, in fruit $0.5-0.6 \mathrm{~cm}$ long, sparsely puberulous, Fruit ellipsoid or ovoid, to $2 \times 1.4 \mathrm{~cm}$, green, maturing deep violet to black, apex rounded, with prickle, smooth, glabrous; seeds 1 , ellipsoid, to $1.7 \times 1 \times 0.7 \mathrm{~cm}$, slightly laterally compressed, scar linear, extending the full length of the seed, 0.3 $\mathrm{cm}$ wide.

Notes. Tree to $12 \mathrm{~m}$ high and 10 $\mathrm{cm}$ diam., slash exuding scarce milky latex; rain, savanna and mountain savanna forest over sand, laterite or granite, to $700 \mathrm{~m}$ altitude.

Distribution. Brazil (Amapá, Pará), Guianas.

\section{Pouteria trilocularis Cronquist $\mathbf{P l}$. 17, fig. 1}

Leaves spaced, coriaceous, glabrous, with 7-14 pairs of secondary veins. Fascicles axillary and in the axils of fallen leaves, 5-15-flowered, 


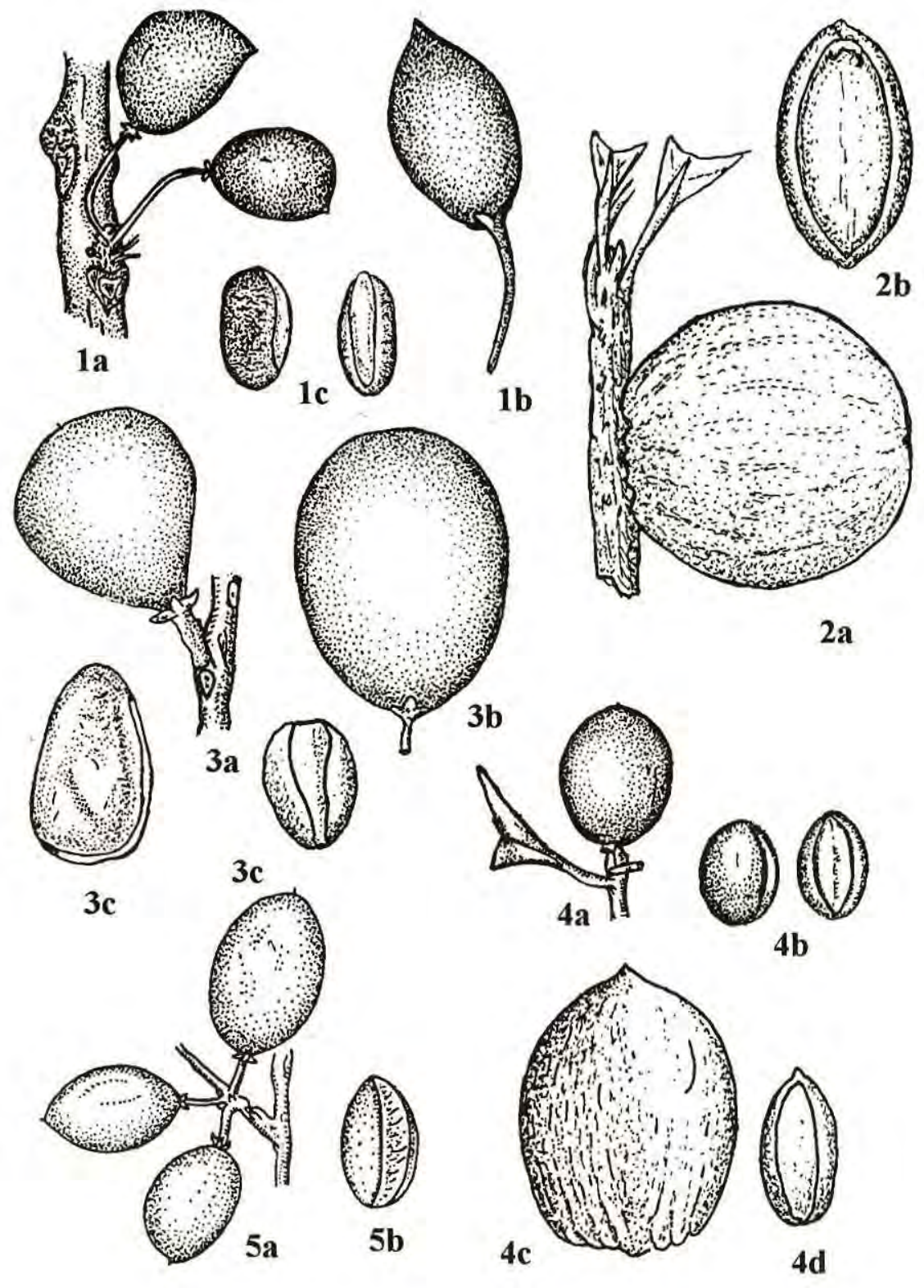

PI 16. Figs. 1-5. SAPOTACEAE. 1. Pouteria pubescens, a. infructescence; b. other fruit type; c. seed, lateral and frontal view (Van Roosmalen 149). 2. P. putamen-ovi, a. fruit; b. s e e d, frontal view (Rimachi 4406). 3. P. ramiflora, a. fruit; b. fruit; $c$. seed, lateral and frontal view (Van Roosmalen 141, 151). 4. P. reticulata subsp. reticulata, a. fruit; b. seed, lateral and frontal view (Van Roosmalen 152, 153); c. fruit; d. seed, frontal view (Pennington et al. 11489). 5. P. sagotiana , a. infructescence; b. seed (Van Roosmalen 1615). 
flowers unisexual, sepals $5,0.3-0.5 \mathrm{~cm}$ long, appressed puberulous; pedicels 0.4-1.6 cm long, in fruit stout, to $1 \mathrm{~cm}$ diam., appressed puberulous. Fruit ovoid to globose, $4-5.5 \mathrm{~cm}$ long, apex rounded, base truncate, maturing yellow or orange, strongly tuberculate to almost smooth, glabrous; seeds 1-3, ellipsoid, 2.5-3.5 cm long, plano-convex or shaped like the segment of an orange (depending of the amount of seeds), testa smooth, shining, scar the length of the seed, sometimes extending over the base and apex, $0.8-1.8 \mathrm{~cm}$ wide.

Notes. Tree to $35 \mathrm{~m}$ high and 75 $\mathrm{cm}$ diam., with to $1.5 \mathrm{~m}$ high buttresses, bark greyish-brown, fissured or scaly, peeling off in rounded flakes, slash light brown, exuding copious white, fast flowing latex; rain and savanna forest on non-flooded or periodically flooded land, up to $1,100 \mathrm{~m}$ altitude in wet montane forest.

Distribution. Bolivia, Brazil (Acre, Amazonas, Mato Grosso, Pará, Rondônia), Colombia, Ecuador, Peru, Venezuela.

\section{Pouteria ucuqui Pires \& Schultes} tucuru, ucuquí (B) Pl. 17, fig. 2

Leaves spaced, coriaceous, appressed brown-puberulous below, with 9-14 pairs of secondary veins. Fascicles axillary and densely clustered below the leaves, many-flowered, flowers unisexual, sepals 5, 0.15-0.2 $\mathrm{cm}$ long, puberulous; pedicels $0.2-0.3$ cm long, appressed ferruginouspuberulous. Fruit obovoid, 10-11 x $7.5-8 \mathrm{~cm}$, apex rounded, base tapered, maturing yellowish, epicarp hard, thick, smooth, glabrous, pulp soft and whitish resembling that of an avogado; seeds $1-2,7-8 \mathrm{~cm}$ long, somewhat laterally compressed, apex and base acute to obtuse, testa smooth, shining, scar extending the full length of the seed, $1.5-1.8 \mathrm{~cm}$ wide near the base, tapering toward the apex.

Notes. Tree to $35 \mathrm{~m}$ high and $100 \mathrm{~cm}$ diam., with up to $2 \mathrm{~m}$ high buttresses and cylindrical bole, bark dark brown, thick and soft, slash reddish exuding copious watery white latex; hillside forest on well drained, non-flooded soil, to $250 \mathrm{~m}$ altitude.

Distribution. Brazil (NW Amazonas), Am. Colombia, Am. Venezuela.

\section{Pouteria vernicosa Pennington}

abiurana (floribunda) (B)

Leaves spaced, coriaceous, glabrous, with 9-12 pairs of secondary veins. Fascicles borne below the leaves, 5 -10-flowered, sepals 5 , ovate, $0.15-0.2 \mathrm{~cm}$ long; pedicels $0.2-1.1 \mathrm{~cm}$ long. Fruit unknown.

Notes. Tree to $35 \mathrm{~m}$ high and 50 $\mathrm{cm}$ diam.; rain and savanna forest on non-flooded land, to $200 \mathrm{~m}$ altitude.

Distribution. Brazil (Amazonas), Am. Peru.

Pouteria virescens Baehni asipoko(balli) (A); abiurana (B) Pl. 18, fig. 1

Leaves spaced, coriaceous, glabrous, with 7-12 pairs of secondary veins. Fascicles axillary and below the leaves, 3-10-flowered, flowers unisexual, sepals 5 , male ones ca. $0.4 \mathrm{~cm}$ long, female ones ca. $0.25 \mathrm{~cm}$ long, puberulous, in fruit three larger ones 


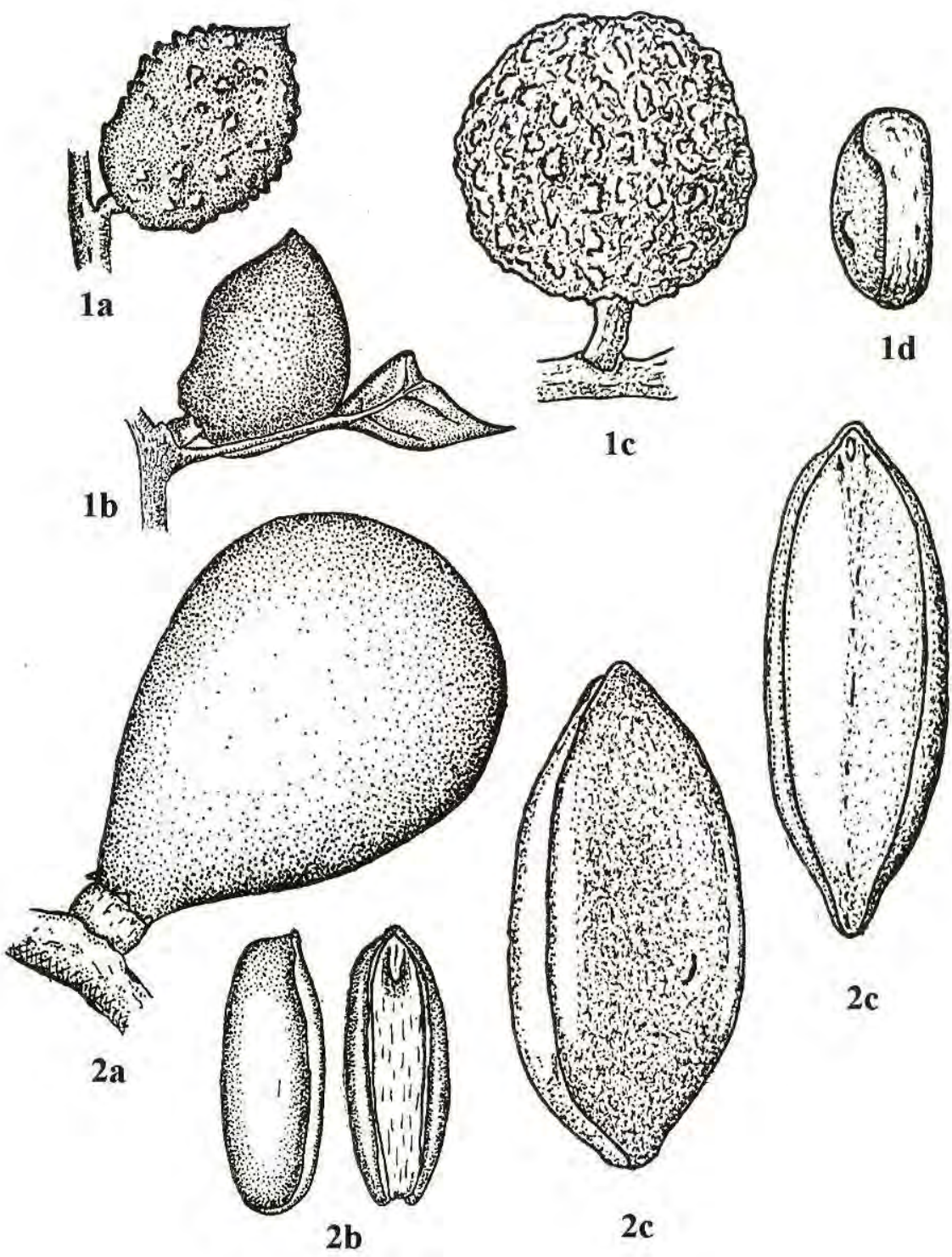

PI. 17. Figs. 1-2. SAPOTACEAE. 1. Pouteria trilocularis, a. fruit; b. smooth fruit (INPA 135585); c. larger tuberculate fruit; d. seed (Liesner \& González 10580). 2. P. ucuqui, a. fruit; b. seed, lateral and frontal view (Van Roosmalen 15); c. seed from larger fruit, lateral and frontal view (Schultes \& López 5870). 
acute-ovate, $0.5 \times 0.5 \mathrm{~cm}$, two smaller ones $0.3 \times 0.3 \mathrm{~cm}$; pedicels $0.3-0.7 \mathrm{~cm}$ long, appressed puberulous, in fruit to $1.2 \mathrm{~cm}$ long and $0.4 \mathrm{~cm}$ diam. Fruit broadly ellipsoid, $5.3 \times 3.5$ to $6.1 \times 4.4$ $\mathrm{cm}$, sometimes $7.5 \times 7 \times 6 \mathrm{~cm} \mathrm{(2-}$ seeded) to $9.8 \times 9.4 \mathrm{~cm}$ (4-seeded), apex obtuse, with sunken prickle, base truncate, maturing orange or red, smooth, velutinous, glabrescent, pulp yellow; seeds 1-2(-4), ellipsoid, 3.6 x $1.5 \times 1.4 \mathrm{~cm}$, sometimes to $6 \times 3.5 \times$ $3 \mathrm{~cm}$, slightly plano-convex, rounded at base, acuminate at apex, testa finely wrinkled to verruculose, shining, light brown, adherent to the pulp, scar not extending the full length of the seed, or sometimes extending around the base, elliptic, $3.1 \times 1.2 \mathrm{~cm}$, sometimes $6 \times 2.5 \mathrm{~cm}$, dull brown, verruculose.

Notes. Tree to $30 \mathrm{~m}$ high and 45 $\mathrm{cm}$ diam., with to $2 \mathrm{~m}$ high buttresses and a reddish-brown, scaling bark, slash exuding thick white latex; immature seeds were seen predated upon by black bearded sakis (Chiropotes satanas chiropotes) (Frazão, 1992) and the ripe pulp was seen eaten by golden-faced sakis (Pithecia pithecia chrysocephala) (Setz, 1993) and by Guianan brown capuchin monkeys (Cebus apella apella) (Spironelo, pers. comm.), $80 \mathrm{~km}$ north of Manaus, Amazonas, Brazil; rain and savanna forest on non-flooded land.

Distribution. Brazil (Amazonas), Fr. Guiana, Guyana.

Pouteria williamii (Aubréville \&

Pellegrin) Pennington

abiurana (B) Pl. 18, fig. 2

Leaves spaced, thinly coriaceous, glabrous, with $8-12$ pairs of secondary veins. Fascicles axillary and below the leaves, 3-10-flowered, sepals $5,0.2 \mathrm{~cm}$ long, appressed puberulous; pedicels $0.4-0.6 \mathrm{~cm}$ long, appressed puberulous. Fruit ellipsoid, ca. $4 \times 3 \mathrm{~cm}$, apex acute, base obtuse, smooth, golden-brown velvety; seeds 1, broadly ellipsoid, ca. $2.3 \times 2 \mathrm{~cm}$, apex and base rounded, testa smooth, dull brown, scar extending around the base, covering slightly more than half the seed surface.

Notes. Tree to $20 \mathrm{~m}$ high and 40 $\mathrm{cm}$ diam., slash exuding yellowish latex; lowland rain forest over sand.

Distribution. Brazil (Amazonas), Fr. Guiana.

\section{Pouteria section 2. Oxythece (Miquel) Eyma}

Leaves with obscure higher order venation, usually glaucous below. Calyx (4-)5-6-merous. Seed laterally compressed or not, scar adaxial, rarely extending around the base, broad or narrow.

\section{Pouteria ambelaniifolia (Sandwith) Pennington PI. 18, fig. 3}

Leaves spaced, spirally arranged or almost opposite, coriaceous, glaucous below, glabrous or appressedpuberulous, with 7-13 pairs of secondary veins. Fascicles axillary and below the leaves, 2-7-flowered, flowers unisexual, sepals 5-6, 0.5-0.6 cm long, appressed puberulous; pedicels 0.4-0.6 $\mathrm{cm}$ long, appressed puberulous. Fruit globose, $3-3.2 \mathrm{~cm}$ in diam., maturing yellow, smooth, appressed puberulous to glabrescent; seeds 1-2, ellipsoid, ca. $2.1 \mathrm{~cm}$ long, slightly laterally compressed, with rounded apex and base, testa smooth, shining, scar almost full- 
length, elliptic, ca. $0.9 \mathrm{~cm}$ wide.

Notes. Tree to $32 \mathrm{~m}$ high and 60 cm diam., with steep buttresses, bark grey-brown, vertically cracked, peeling in irregular plates, slash with orange streaks, exuding little white latex; lowland terra-firme rain forest, between 200 and $500 \mathrm{~m}$ altitude.

Distribution. Brazil (Amapá, Amazonas), Fr. Guiana, Guyana.

Pouteria cuspidata (A. de Candolle)

Baehni subsp. cuspidata

kokeritiballi, kooteritiballi (A); abiurana (flor miuda), abiuranamatamata, jarai, maparajuba-de-mata (B) Pl. 18, fig. 4

Leaves spaced, coriaceous, glaucous and appressed puberulous or glabrous below, with 10-20 pairs of secondary veins, not impressed below. Fascicles axillary and below the leaves, 2 25-flowered, flowers unisexual, sepals (4-)5(-6), 0.2-0.3 cm long, appressed puberulous; pedicels $0.4-0.6 \mathrm{~cm}$ long, appressed puberulous. Fruit ellipsoid to obovoid, $1.8-3.3 \times 1.5-2 \mathrm{~cm}$, apex rounded or obtuse, sometimes acuminate over $0.1-0.3 \mathrm{~cm}$, base acute to tapered, sometimes forming an up to $1 \mathrm{~cm}$ long stipe, epicarp thin, brittle, maturing yellow to orange, smooth, ferruginouspulverulent at least near base, pulp white, edible, sweet tasting; seeds $1(-2)$, ellipsoid to broadly oblong, 1.2-1.6 x 0.9-1.2 x 0.6-0.9 cm long, apex and base rounded or obtuse, not adherent to the pulp, testa brown, smooth, shining, scar mostly extending around the base, 1.1$1.6 \times 0.2-0.25 \mathrm{~cm}$, dull brown.

Notes. Tree to $30 \mathrm{~m}$ high and 60 $\mathrm{cm}$ diam., with slender, up to $1.5 \mathrm{~m}$ high buttresses and a fluted trunk, bark smooth or granular, whitish to greyishbrown, slash pink, exuding little white latex; Defler (pers. comm.) saw Humboldt's woolly monkeys (Lagothrix lagotricha lagotricha) feeding on the pulp, swallowing and dispersing the seeds, in terra-firme forest along the lower Río Apaporis, Colombia; usually found along river margins, sometimes on seasonally or permanently flooded land, also on nonflooded land to $550 \mathrm{~m}$ altitude.

Distribution. Bolivia, Brazil (Amapá, Amazonas, Pará, Rondônia, Roraima), Guyana, Am. Colombia, Am. Peru, Am. Venezuela.

Pouteria cuspidata (A. de Candolle)

Baehni subsp. dura (Eyma)

Pennington

kokoritiballi (A); akwasiba (S); abiurana (arana), pau-doce (B) Pl. 18, fig. 5

Leaves spaced, coriaceous, not glaucous below, appressed puberulous or glabrous below, secondary veins $10-$ 20 pairs, impressed on both surfaces. Fascicles axillary and below the leaves, 2-25-flowered, flowers unisexual, sepals (4-)5(-6), broadly ovate, in fruit $0.2-0.3 \mathrm{~cm}$ long, appressed puberulous; fruiting pedicels stout, $0.5-0.6 \mathrm{~cm}$ long. Fruit obovoid, to 2.6 x $2 \mathrm{~cm}$, green to yellow or orange, apex abruptly acuminate over $0.1 \mathrm{~cm}$, base tapering over to $0.5 \mathrm{~cm}$, smooth or obscurely veined, ferruginous-pulverulent to glabrous; seeds 1, ellipsoid to broadly oblong, to $1.5 \times 1.1 \times 0.8$ $\mathrm{cm}$, apex and base rounded or obtuse, testa smooth, shining, scar full-length, mostly extending around the base, 1.5 $\mathrm{x} 0.4 \mathrm{~cm}$. 
Notes. Tree to $35 \mathrm{~m}$ high and 50 $\mathrm{cm}$ diam., bole cylindrical, without buttresses, bark pale brown, thin, flaky, slash exuding copious white latex; pied bare-face tamarins (Saguinus bicolor bicolor) have been seen feeding on the mature pulp swallowing and dispersing the seeds, in savanna forest on white sand $20 \mathrm{~km}$ north of Manaus, Amazonas, Brazil (Egler, pers. comm.); upland rain and savanna ("wallaba") forest on non-flooded land, to $1,250 \mathrm{~m}$ altitude.

Distribution. Brazil (Amazonas), Am. Colombia, Guyana, Am. Peru, Suriname, Venezuela.

Pouteria cuspidata (A. de Candolle) Baehni subsp. robusta (Martius \& Eichler) Pennington

boroweballi (A); pinto-boletri (S); abiurana, cabeçudo, majarajuba (B) Pl. 18, fig. 6

Leaves spaced, coriaceous, appressed puberulous or glabrous below, not glaucous, secondary veins $10-20$ pairs, not impressed on lower surface. Fascicles axillary and below the leaves, 2-25-flowered, flowers unisexual, sepals (4-)5(-6), 0.2-0.3 cm long, ovate, appressed puberulous; pedicels $0.4-1.2 \mathrm{~cm}$ long, brown appressed puberulous, in fruit stout, to $1.3 \mathrm{~cm}$ long. Fruit (oblong-)obovoid to fusiform, 2.8-3.5(-4.8) x 1.6-1.9(-3.2) $\mathrm{cm}$, apex obtusely acuminate over 0.2 $0.4 \mathrm{~cm}$, apiculate, base subcylindrical and tapering over $0.5-0.8 \mathrm{~cm}$, yellow to red or purplish(-black), glossy; seeds 1 , ellipsoid to broadly oblong, $2.1-2.7 \times 1.2-1.3 \times 0.9-1 \mathrm{~cm}$, laterally compressed, testa dark brown, smooth, shining, scar full-length, $0.3 \mathrm{~cm}$ wide.

Notes. Tree to $50 \mathrm{~m}$ high and 72 $\mathrm{cm}$ diam., with branched, slender, slightly concave, up to $1 \mathrm{~m}$ high buttresses, bole cylindrical, bark pale greyish-buff, finely vertically cracked, slash pinkish-brown, thin, exuding little sticky white latex; Frazâo (1991) reports on frequent seed predation by black bearded sakis (Chiropotes satanas chiropotes) $80 \mathrm{~km}$ north of Manaus, Amazonas, Brazil, whereas Peres (pers. comm.) observed buffy sakis (Pithecia albicans) and parrots (Amazona sp.) feeding on immature seeds, and tamarins (Saguinus mystax pileatus and $S$. fuscicollis avilapiresi) (Peres, 1993) and Geoffroy's woolly monkeys (Lagothrix lagotricha cana) (Peres, 1994) feeding on mature pulp dispersing the seeds endochorically; periodically flooded forest, also in terra-firme rain forest and white-sand savanna forest up to $2,000 \mathrm{~m}$ altitude.

Distribution. Am. Brazil (Amapá, Amazonas, Pará, Rondônia), Am. Colombia, French Guiana, Am. Peru, Suriname, Venezuela.

\section{Pouteria elegans (A. de Candolle) Baehni}

abiurana, cajurana, caramuri, jarai, maparajuba, massarandubinha (B) Pl. 19, fig. 1

Leaves spaced, coriaceous, glabrous or whitish appressed puberulous below, greyish-glaucous, with 11-20 pairs of secondary veins. Fascicles axillary and below the leaves, 2-12(20)-flowered, flowers unisexual, sepals (4-)5-6, ovate, appressed puberulous to glabrous; pedicels 0.3- 


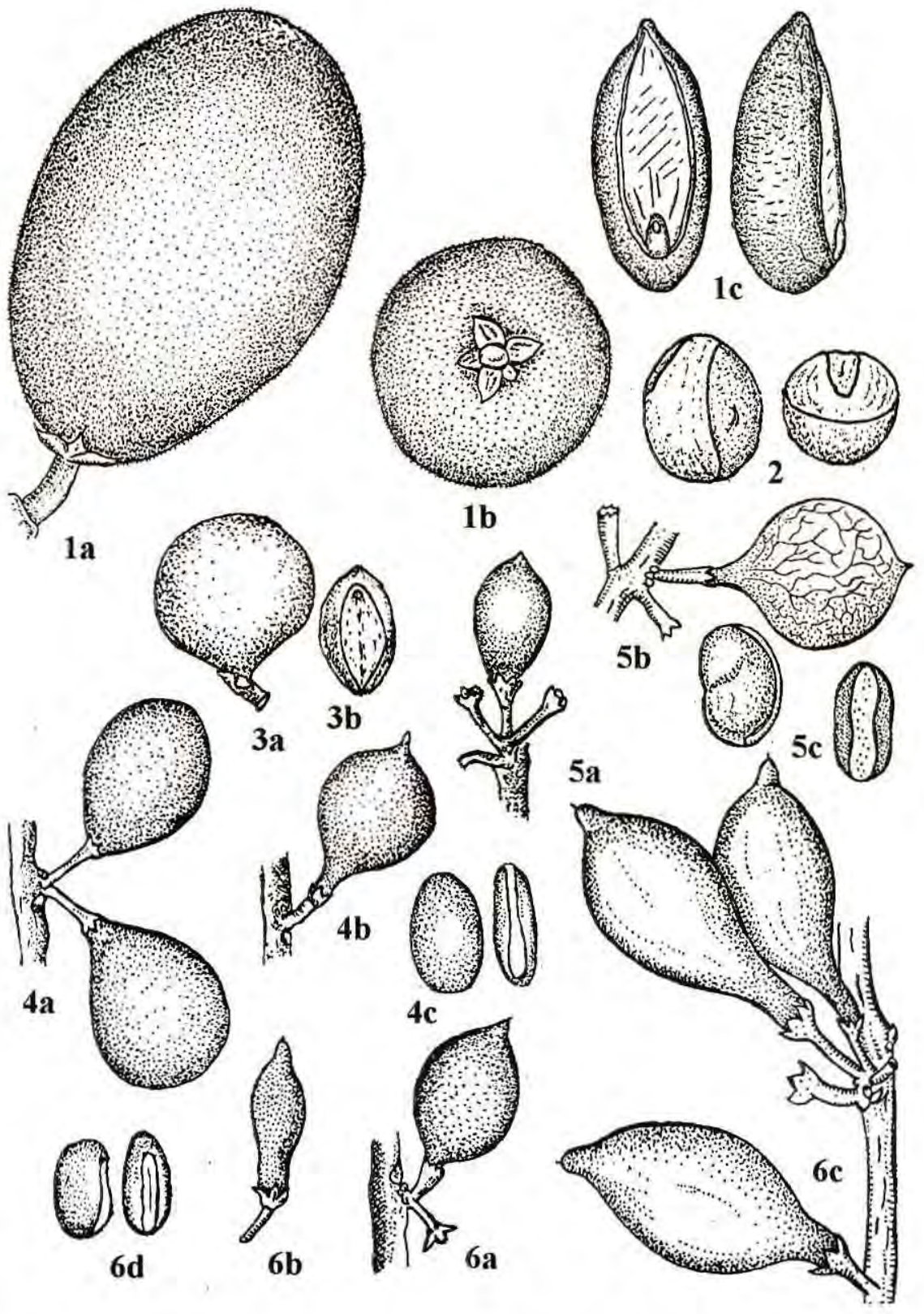

Pl. 18. Figs. 1-6. SAPOTACEAE. 1. Pouteria virescens, a. fruit; b. fruit from below; c. seed (Setz 123). 2. P. williamii, seed seen from aside and above (Grenand 780). 3. P. ambelaniifolia, a. fruit; b. seed, frontal view (Marcano-Berti 217). 4. P. cuspidata subsp. cuspidata, a,b. fruit; c. seed (Defler 122). 5. P. cuspidata subsp. dura, a. young fruit; b. fruit; c. seed (Van Roosmalen 176). 6. P. cuspidata subsp. robusta, a,b. young fruit; c. ripe infructescence; d. seed (Frazão 68; Peres 196, 399, 556, 580). 
$0.9 \mathrm{~cm}$ long, appressed puberulous. Fruit narrowly oblong or ellipsoid, 3$4.5 \times 2.2 \mathrm{~cm}$, apex acute to narrowly attenuate, base narrowly tapered to truncate, at first greenish-brown, maturing glossy black, smooth, minutely brown appressed puberulous to glabrous, epicarp $0.4 \mathrm{~cm}$ thick, purple from inside, not adherent to edible, sweet-tasting pulp; seeds 1 , narrowly oblong or ellipsoid, $3.0-4.1 \times 1 \mathrm{~cm}$, not laterally compressed, adaxially convex, abaxially slightly concave, apex acute, base acute to rounded, testa smooth, shining, pale brown, scar full-length, $0.1-0.4 \mathrm{~cm}$ wide.

Notes. Tree to $10 \mathrm{~m}$, occasionally to ca. $20 \mathrm{~m}$ high and $50 \mathrm{~cm}$ diam., flowering when less than $5 \mathrm{~m}$ high, bark dark brown and fissured, slash exuding copious sticky white latex; periodically or permanently flooded forest (igapó and várzea) along rivers and white-sand savannas.

Distribution. Am. Brazil (Amazonas, Pará, Roraima), Am. Colombia, Guyana, S and SW Venezuela.

\section{Pouteria gabrielensis (Gilly ex}

Aubréville) Pennington

abiurana, cumandu-açú (B) PI.

\section{9, fig. 2}

Leaves spaced, coriaceous, golden-ferruginous sericeous below giving a rufous appearance, with 2025 pairs of secondary veins. Fascicles axillary and below the leaves, 5-20flowered, flowers unisexual, sepals 5, ovate, ca. $0.2 \mathrm{~cm}$ long, united at base, appressed puberulous; pedicels $0.3-0.6$ $\mathrm{cm}$ long, shortly sericeous, in fruit to $1.2 \mathrm{~cm}$ long. Fruit narrowly oblong, 3 x $1 \mathrm{~cm}$, or obovoid, ca. $2.2 \times 1.4 \mathrm{~cm}$, base tapered over $0.4 \mathrm{~cm}$, apex abruptly acuminate over $0.2 \mathrm{~cm}$, pericarp thin, brittle, smooth, finely appressed ferruginous puberulous; seeds 1 , narrowly oblong to ellipsoid, 1.5 $2.3 \times 1 \mathrm{~cm}$, rounded or obtuse at both ends, testa smooth, pale brown, shining, scar full-length, $0.2-0.25 \mathrm{~cm}$ wide.

Notes. Tree to $12 \mathrm{~m}$ high, slash exuding white latex; Boubli (1997) observed Humboldt's black-headed uacaries (Cacajao m. melanocephalus) predating upon the immature seeds of this species along the R. Cauaburi in Pico da Neblina National Park (NW Amazonas, Brazil); periodically flooded forest (igapó) and savanna forest (called caatinga of the Upper Rio Negro), up to $200 \mathrm{~m}$ altitude.

Distribution. NW Am. Brazil (Amazonas), Am. Colombia, S Venezuela.

\section{Pouteria opposita (Ducke)}

Pennington

abiú, caramuri (B) PI. 19, fig. 3

Leaves spaced, opposite, coriaceous, finely golden appressed puberulous below, with 9-13 pairs of secondary veins. Fascicles axillary and below the leaves, 5-10-flowered, sepals 5-6, suborbicular, $0.3 \mathrm{~cm}$ long, appressed puberulous; pedicels 0.3-0.6 $\mathrm{cm}$ long, appressed puberulous. Fruit broadly ellipsoid, 3.4-4 × $3 \mathrm{~cm}$, apex rounded, base obtuse, at first green, maturing orange-yellow, epicarp woody or thick coriaceous, smooth, glabrous or glabrescent, pulp fleshy, white, sweet-tasting, easy to separate; seeds $1-2,2.2-2.3 \times 1.2-1.4 \times 1.3 \mathrm{~cm}$, rounded or obtuse at apex and base, the abaxial side keeled, testa smooth, 


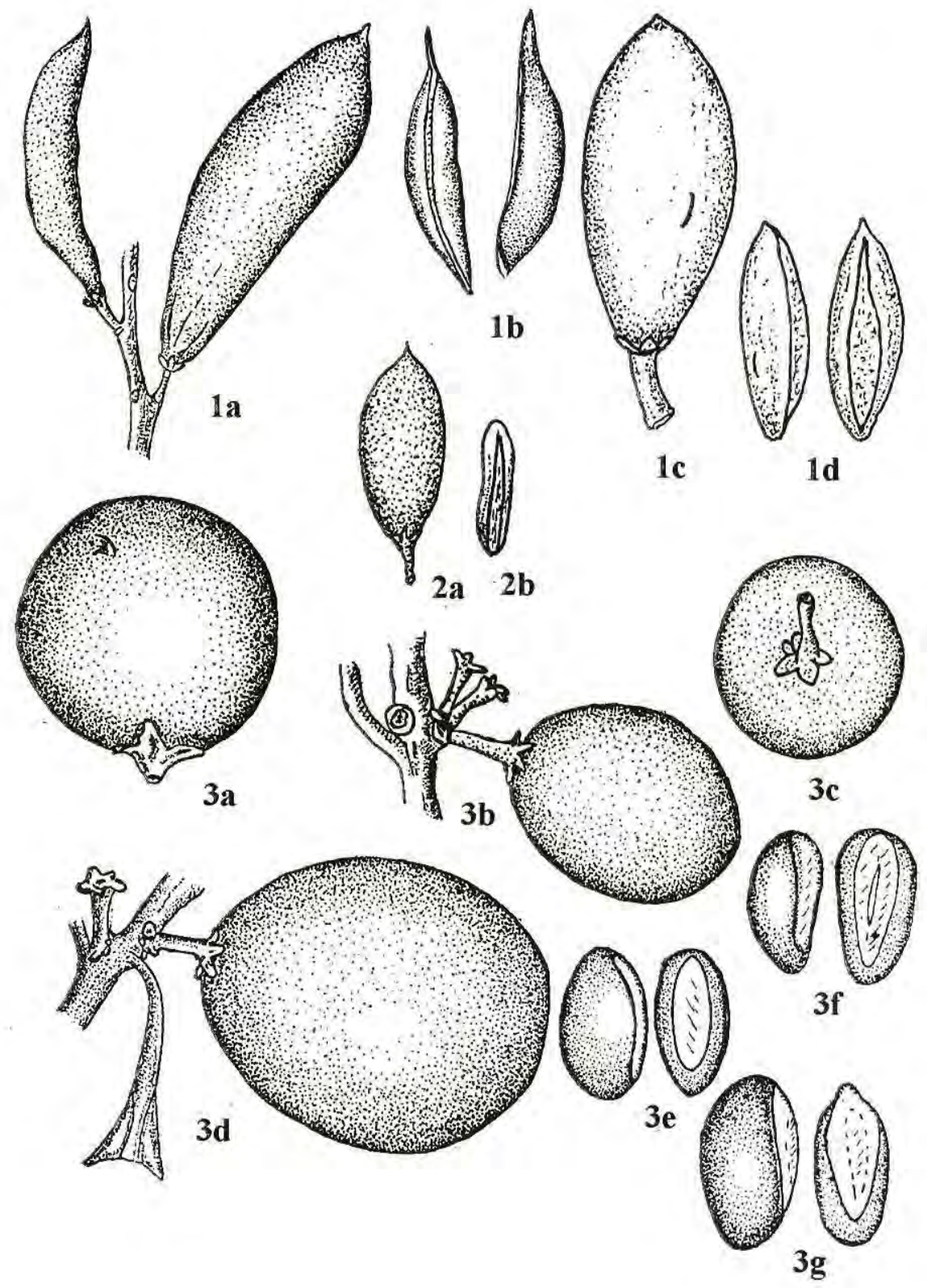

PI. 19. Figs. 1-3. SAPOTACEAE. 1. Pouteria elegans, a. dried infructescence; b. seed, frontal and lateral view; c. fruit; $\mathrm{d}$. other seed, lateral and frontal view (Van Roosmalen 118). 2. $P$. gabrielensis, a. fruit; b. seed (Schultes \& López 9856). 3. P. opposita, a. fruit; b. fruit; c. fruit from below; d. other fruit; e,f,g. different seeds, lateral and frontal view (Peres 744; Van Roosmalen 25). 
light brown, shining, scar about $3 / 4$ the length of the seed, $0.5-0.7 \mathrm{~cm}$ wide, dull brown; seed weighing 12-17 grams.

Notes. Tree to $35 \mathrm{~m}$ high and 45 $\mathrm{cm}$ diam., with low buttresses, slash exuding little white latex; in the R. Urucú region (Amazonas, Brazil), Peres (1994) observed buffy sakis (Pithecia albicans) feeding on immature seeds, and Geoffroy's woolly monkeys (Lagothrix lagotricha cana) on the mature pulp dispersing the seeds endochorically, whereas Defler (pers. comm.) saw Humboldt's woolly monkeys (Lagothrix l. lagotricha) feeding on mature fruits, swallowing the pulp together with the seeds; terrafirme rain forest, up to $800 \mathrm{~m}$ altitude.

Distribution. Am. Brazil (Amazonas, Pará), Am. Colombia, Am. Peru.

\section{Pouteria rigida (Martius \& Eichler) Radlkofer Pl. 20, fig. 1}

Leaves spaced, spirally arranged or subopposite or subverticillate, strongly coriaceous and revolute, often glaucous below, ferruginous-tomentose turning greyish, soon glabrescent, with 6-9 pairs of secondary veins. Fascicles axillary, 1-6-flowered, flowers unisexual, sepals 5, ferruginous-pubescent; pedicels $0.1-0.4 \mathrm{~cm}$ long, ferruginous-pubescent. Fruit obovoid to subglobose, $1-1.5 \mathrm{~cm}$ diam., apex rounded, base obtuse, maturing orange-brown, smooth, ferruginous-pubescent; seeds 1 , ellipsoid, 0.8 $\mathrm{cm}$ long, rounded at both ends, testa smooth, shining, scar almost full-length, ca. $0.15 \mathrm{~cm}$ wide.

Notes. Small tree or shrub to 8 (-
15) $\mathrm{m}$ high, slash exuding copious sticky white latex; sandstone scrub and forest islands in savanna, dwarf mossy forest over sandstone, and forest dominated by Bonnetia roraimae at 450 2,200 m altitude.

Distribution. Brazil (Roraima), Guyana, S Venezuela.

Pouteria scrobiculata Monachino ex Pennington

Leaves spirally arranged, rarely subopposite, thinly coriaceous, margins revolute, glaucous below, silvery or bluish appressed sericeous, with 613 pairs of secondary veins. Fascicles axillary and below the leaves, 2-8flowered, flowers unisexual, sepals 5$6,0.2 \mathrm{~cm}$ long, golden sericeous; pedicels $0.4-0.7(-1) \mathrm{cm}$ long, golden sericeous. Fruit not known.

Notes. Tree to $20 \mathrm{~m}$ high; wet or riverside forest on steep slopes at 700$1,600 \mathrm{~m}$ altitude.

Distribution. N Brazil (Amazonas, Serra Aracá), S. Venezuela (highlands).

Pouteria section 3. Oligotheca (A. de Candolle) Baehni

Leaves with oblique, horizontal or obscure tertiary venation. Calyx 5 merous. Seed laterally compressed, testa smooth or wrinkled, often adhering to the pulp, scar narrow, adaxial, full-length.

Pouteria cayennensis (A. de Candolle) Eyma PI. 20, fig. 2

Leaves clustered, margin often revolute, coriaceous, at first densely ferruginous tomentose, glabrescent, with 7-11 pairs of secondary veins. 
Fascicles axillary and clustered below the leaves, 2-8-flowered, sepals $0.5 \mathrm{~cm}$ long, ferruginous crisped-pubescent; pedicels $0.5-1 \mathrm{~cm}$ long, densely ferruginous crisped-pubescent. Fruit ellipsoid, ca. $3.5 \times 2 \mathrm{~cm}$, apex rounded or truncate, base tapered, maturing yellow, smooth or slightly warty, glabrous or with some indumentum around the base, outer pericarp tough and pinkish, the inner pericarp or pulp 0.3-0.4 cm thick, transparent, gelatinous, adhering to the seed testa, sweettasting; seeds 1 , ellipsoid, $2.3-2.5 \mathrm{~cm}$ long, testa smooth, shining, scar (almost) full-length, $0.2-0.4 \mathrm{~cm}$ wide.

Notes. Tree to $46 \mathrm{~m}$ high and $1 \mathrm{~m}$ diam., with steep, rounded, branched, up to $2 \mathrm{~m}$ high buttresses, trunk fluted or cylindrical, bark brown to dark grey, slightly vertically cracked or scaling, slash pinkish or straw colored, exuding copious sticky white latex; lowland rain and savanna forest, and lower montane forest to $1,200 \mathrm{~m}$ altitude.

Distribution. Fr. Guiana, Guyana, S Venezuela.

Pouteria laevigata (Martius) Radlkofer

abiurana (da casca grossa, sapota), caramury, caucho (B) PI. 20, fig. 3

Leaves spaced or loosely clustered at shoot apex, spirally arranged, thinly coriaceous, with 9-13 pairs of secondary veins. Fascicles axillary, mostly in the axils of shed leaves, 215-flowered, flowers bisexual, sepals $0.2-0.3 \mathrm{~cm}$ long, pedicels $0.2-0.3 \mathrm{~cm}$ long. Fruit globose or obovoid, $6-9 \mathrm{~cm}$ diam., apex rounded, base truncate, maturing bright yellow to orange, epicarp smooth, brown or black lenticellate or rough, glabrous, to $0.7 \mathrm{~cm}$ thick, flesh firm, (pinkish-)cream to orange; seeds $2-4$, ellipsoid to slightly plano-convex, 3.3-3.7(-4.2) x $2.2 \times 1.6$ $\mathrm{cm}$, testa dull brown, rugulose, adherent to greenish gelatinous pulp, scar extending most of the seed length, ca. $3.2 \mathrm{~cm}$ long and $0.3-0.6 \mathrm{~cm}$ wide.

Notes. Tree to $50 \mathrm{~m}$ high and 65 $\mathrm{cm}$ diam., trunk cylindrical, without buttresses, bark ca. $2 \mathrm{~cm}$ thick, pale brown, finely vertically cracked, slash cream to pale brown, exuding sticky white latex; mature pulp and flesh are reported to be consumed by Humboldt's woolly monkeys (Lagothrix $l$. lagotricha) at the lower R. Apaporis, Am. Colombia (Defler, pers. comm.) dispersing the seeds endochorically, whereas spider monkeys (Ateles paniscus) were seen swallowing the seeds together with pulp and flesh, dispersing the seeds, $20 \mathrm{~km}$ north of Manaus, Am. Brazil; lowland rain forest and terra-firme rain forest on slopes, also found in riverine forest on periodically or permanently flooded land (igapó), at $100-400 \mathrm{~m}$ altitude.

Distribution. Am. Brazil (Acre, Amazonas, Pará), Am. Colombia, Fr. Guiana, Am. Peru, Am. Venezuela.

Pouteria oblanceolata Pires abiú, abiurana Pl. 20, fig. 4

Leaves spaced or loosely clustered, oblanceolate, chartaceous, with 7-10 pairs of secondary veins. Fascicles in the axils of shed leaves, 3-15flowered, flowers unisexual, sepals 0.3 $\mathrm{cm}$ long, sericeous inside, in fruit to $0.5 \mathrm{~cm}$ long and $0.6 \mathrm{~cm}$ wide at the base; pedicels $0.3-0.5 \mathrm{~cm}$ long, sparsely appressed puberulous, in fruit to $1.7 \mathrm{~cm}$ long. Fruit narrowly obovoid 
or ellipsoid, 4.3-5.1 x 2.9-3.1 cm, apex rounded, with prickle, base tapered, maturing yellow to bright orange, epicarp smooth, glabrous, the base with some residual hair; seeds 1 , strongly laterally compressed, to $2.8-3.6 \times 1.4$ $1.5 \times 0.9-1 \mathrm{~cm}$, apex rounded, base acute, testa smooth, shining, scar 0.2$0.3 \mathrm{~cm}$ wide.

Notes. Tree to $32 \mathrm{~m}$ high and 60 $\mathrm{cm}$ diam., buttresses small, simple or branched, trunk cylindrical but fluted in the lower part, bark blackish- or reddish-brown, narrowly fissured, inner bark orange, slash pink, exuding sticky white latex; Peres (1994) observed Geoffroy's woolly monkeys (Lagothrix lagotricha cana) and widow monkeys or collared titi monkeys (Callicebus torquatus purinus) feeding on the mature pulp swallowing and dispersing the seeds, in the R. Urucú region, Am. Brazil; terra-firme rain and savanna forest over yellow clay or white sand, to $600 \mathrm{~m}$ altitude.

Distribution. Am. Brazil (Amapá, Amazonas, Pará), Fr. Guiana, Am. Peru.

\section{Pouteria oppositifolia (Ducke) Baehni}

abiú, abiurana, abiú ucuubarana, guajara-vermelho (B) Pl. 20, fig. 5

Leaves spaced, (almost) opposite or sometimes spirally arranged, chartaceous, with 15-20 pairs of secondary veins. Fascicles axillary, many-flowered, flowers bisexual, sepals $0.15 \mathrm{~cm}$ long, appressed puberulous; pedicels 0.3-0.45 cm long, appressed puberulous. Fruit obovoid or ellipsoid, 1.9-2.4 x 1.4$1.6 \mathrm{~cm}$, rounded at both ends, maturing yellow or apricot-colored, smooth, glabrous or sparsely appressed puberulous at base; seeds 1, ellipsoid, $1.4-2 \mathrm{~cm}$ long, apex rounded, base slightly tapered, testa finely transversely wrinkled, shining, scar $0.25 \mathrm{~cm}$ wide.

Notes. Tree to $35 \mathrm{~m}$ high and 65 $\mathrm{cm}$ diam.; lowland terra-firme rain and savanna forest.

Distribution. Brazil (Amapá, Pará).

\section{Pouteria tarumanensis Pires}

balata-rosadinha-braba (B) Pl. 20, fig. 6 (this species might be conspecific with $\boldsymbol{P}$. oblanceolata)

Leaves loosely clustered, spirally arranged, coriaceous, with 7-9 pairs of secondary veins. Fascicles axillary and below the leaves, 5-10-flowered, sepals $0.4-0.45 \mathrm{~cm}$ long, broadly ovate; pedicels $0.5-0.7 \mathrm{~cm}$ long, in fruit to 1.2 $\mathrm{cm}$ long. Fruit narrowly obovoid, 2.5 $3 \times 1.9-2.1 \mathrm{~cm}$, apex rounded, with prickle, base slightly tapered and truncate, maturing ochraceous to yellow, smooth, glabrous or with some indumentum at base; seeds $1,1.8 \times 1 \times$ $0.7 \mathrm{~cm}$, apex rounded, base acute, testa smooth, shining, scar $0.15-0.3 \mathrm{~cm}$ wide.

Notes. Tree to $20 \mathrm{~m}$ high and 35 $\mathrm{cm}$ diam., slash with sticky white latex; black bearded sakis (Chiropotes satanas chiropotes) were seen predating on the immature seeds of this species $80 \mathrm{~km}$ north of Manaus (Frazão, 1992), and in the R. Urucú region, Am. Brazil, Peres (pers. comm.) observed white-faced capuchin monkeys (Cebus albifrons unicolor) feeding on the mature pulp; lowland terra-firme rain forest over sand.

Distribution. Am. Brazil (C Amazonas). 

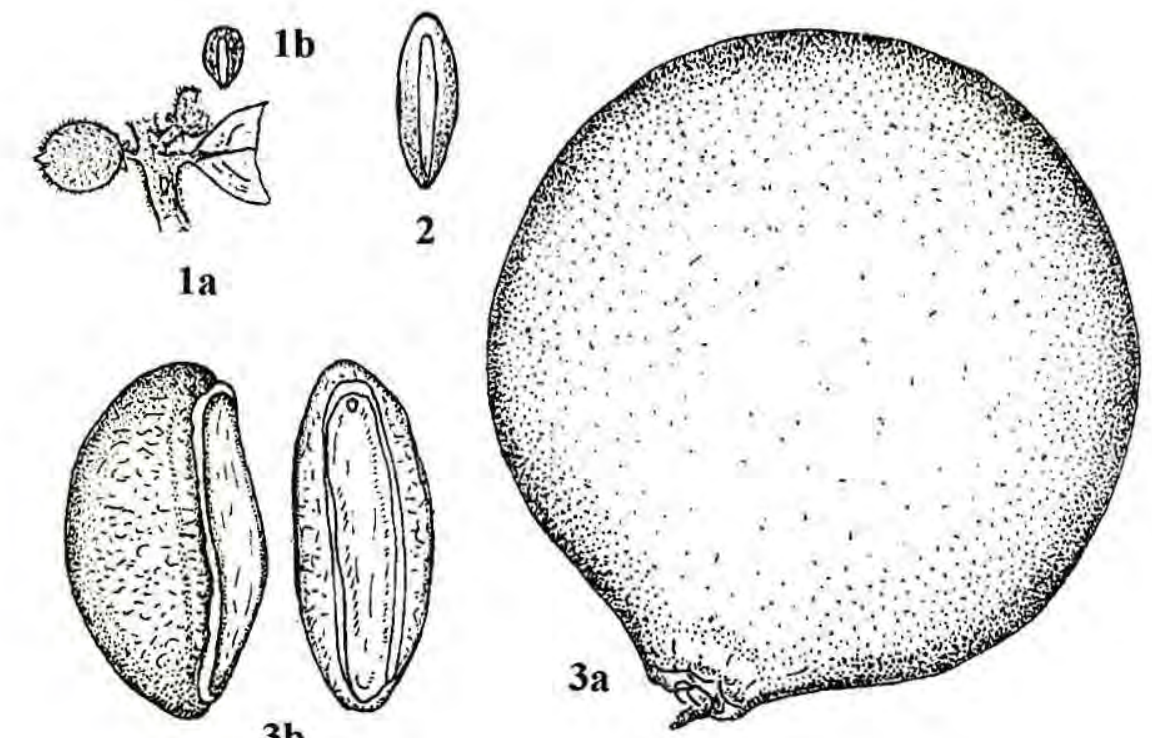

3b

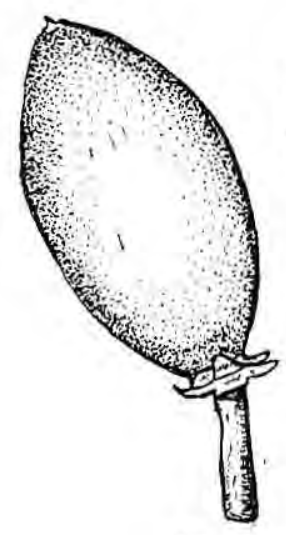

$4 a$
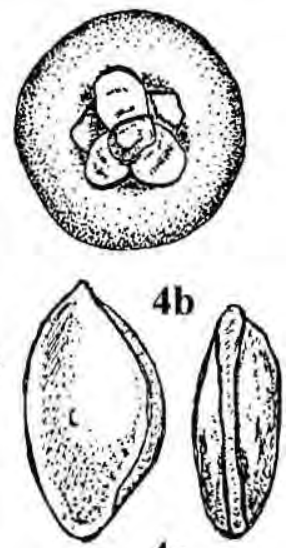

4c
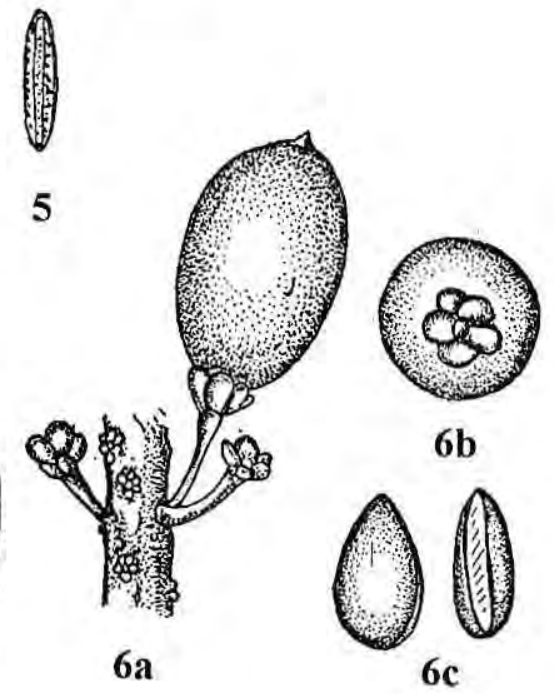

PI. 20. Figs. 1-6. SAPOTACEAE. 1. Pouteria rigida, a. infructescense; b. seed, frontal view (Huber \& Alercón 7462). 2. P. cayennensis, seed, frontal view (Steyermark 60664). 3. P. laevigata, a. fruit; b. seedlateral and frontal view (Van Roosmalen 138). 4. P. oblanceolata, a. fruit; b. fruit from below; c. seed, lateral and frontal view (Van Roosmalen 144). 5. P. oppositifolia, seed, frontal view (Pires \& Black 776). 6. P. tarumanensis, a. fruit; b. fruit from below; c. seed, lateral and frontal view (Van Roosmalen 156). 
Pouteria section 4. Rivicoa (A. de Candolle) Baehni

Leaves with oblique or horizontal tertiary venation. Calyx 5-merous. Fruit with globose or ellipsoid seed, not laterally compressed, scar broad, covering one third of the seed surface up to almost all of it, except for a narrow abaxial strip.

\section{Pouteria exstaminodia Pires \&}

Pennington

Leaves spaced, chartaceous, persistently pale brown sericeous below, with $18-20$ pairs of secondary veins. Fascicles axillary, 5-10-flowered, sepals $0.5 \mathrm{~cm}$ long, both sides appressed puberulous; pedicels 1-1.3 cm long, pubescent. Fruit not known.

Notes. Tree to $30 \mathrm{~m}$ high and 35 $\mathrm{cm}$ diam., slash exuding white latex; lowland terra-firme rain forest.

Distribution. Brazil (Amazonas, R. Uatumã).

Pouteria macrophylla (Lamarck) Eyma abiurana, acará-uba, cutite, cutitiriba (B) PI. 21, fig. 1

Leaves spaced or loosely clustered, chartaceous to thinly coriaceous, puberulous below, with 12-18 pairs of straight, parallel secondary veins. Fascicles axillary and clustered below the leaves, 3-12-flowered, flowers bisexual, sepals $0.3 \times 0.6 \mathrm{~cm}$ and $0.25 \times$ $0.4 \mathrm{~cm}$, densely appressed puberulous; pedicels $0.4-1.8 \mathrm{~cm}$ long, appressed puberulous. Fruit globose or broadly ellipsoid to obliquely ovoid, $6 \times 3.5$ $4.7 \mathrm{~cm}$, apex and base rounded or obtuse, at first green with yellow speckles, maturing yellow, shining, epicarp chartaceous, very thin, easily peeling, smooth, glabrous, pulp yellowish-orange, edible, starchy and sweet tasting; seeds 1-2, broadly ellipsoid (in 1seeded fruit) or plano-convex (in 2seeded fruit), $2-3 \times 2.3 \times 2.3 \mathrm{~cm}$, with a small abaxial crest near the base, testa smooth, brown, shining, scar broad, extending over the base, covering one third to half the seed surface, dull light brown, rugulose and irregularly furrowed.

Notes. Tree to $30 \mathrm{~m}$ high and 40 $\mathrm{cm}$ diam., with small buttresses and fluted trunk, bark blackish-brown, finely and shallowly fissured, slash cream-colored, exuding copious white latex; in Suriname, along the east bank of the Coppename river, red-faced black spider monkeys (Ateles paniscus) fed on the starchy pulp swallowing and exclusively dispersing the large seeds of this species, whereas in Brazil, $20 \mathrm{~km}$ north of Manaus, tapir (Tapirus terrestris) were seen feeding on the whole mature fruits fallen to the ground, crushing the seeds; terra-firme rain forest up to $350 \mathrm{~m}$ altitude, also found in old secondary forest and transitional forest between savanna and savanna forest.

Distribution. Bolivia, Am. Brazil (Acre, Amapá, Amazonas, Mato Grosso, Pará), Fr. Guiana, Am. Peru, Suriname.

Pouteria manaosensis (Aubréville \& Pellegrin) Pennington

djoe-bortri (S); cucutiriba folha-pelada, cutitiriba-pelada, abiúpeludo (B) Pl. 21, fig. 2

Leaves clustered, chartaceous, reddish-brown tomentose to pubescent below, with 19-26 pairs of secondary 
veins. Fascicles axillary, 3-10-flowered, flowers bisexual, sepals (4-)5, 0.5-0.6 cm long, ovate, tomentose, in fruit unequal, three sepals measuring $0.5-0.6 \times 0.6 \mathrm{~cm}$, two $0.2 \times 0.4 \mathrm{~cm}$; pedicels $0.6-1.3 \mathrm{~cm}$ long, tomentose, in fruit to $1.6 \mathrm{~cm}$ long. Fruit (depressed) globose to obovoid, $4.7-5 \mathrm{~cm}$ in diameter, or $5.6 \times 4 \mathrm{~cm}$, sometimes $7.5-10 \mathrm{~cm}$ long, apex rounded or truncate, with prickle, base rounded or tapered and truncate, smooth, reddishbrown velutinous; seeds $1-2(-3)$, globose to plano-convex or shaped like the segment of an orange, $3.4-4 \mathrm{~cm}$ in diameter, rugulose, scar covering almost the whole seed surface leaving only a narrow, drop-like, smooth, shining abaxial strip, measuring ca. $1.9 \times 0.7 \mathrm{~cm}$.

Notes. Tree to $35 \mathrm{~m}$ high and 70 $\mathrm{cm}$ diam., slash exuding white latex; Setz (1993) saw golden-faced sakis (Pithecia pithecia chrysocephala) feeding on the mature pulp of this species, $80 \mathrm{~km}$ north of Manaus, Amazonas; lowland terra-firme rain and savanna forest on hilly terrain up to $650 \mathrm{~m}$ altitude.

Distribution. Brazil Amazonas, Pará, Roraima), Suriname.

Pouteria rodriguesiana Pires \& Pennington

abiú mapara-juba (B)

Leaves loosely clustered, thinly coriaceous, golden-brown appressed puberulous below, with $15-33$ pairs of secondary veins. Fascicles mostly axillary, 3-10-flowered, flowers bisexual, sepals 5, 0.25-0.3 cm long, appressed puberulous; pedicels $0.3-0.4 \mathrm{~cm}$ long, appressed puberulous. Fruit ovoid to globose, $4-5 \mathrm{~cm}$ long, apex and base rounded, smooth, glabrous; seeds 1 , globose, $2-3 \mathrm{~cm}$ diam., testa bony, scar very rough, covering most of the seed, leaving a small smooth strip on the abaxial side.

Notes. Tree to $30 \mathrm{~m}$ high and 50 $\mathrm{cm}$ diam., with steep simple buttresses to $1 \mathrm{~m}$ high, bole sometimes fluted, bark reddish-brown, scaling in rectangular pieces, slash pinkish, exuding sticky white latex; lowland terra-firme rain forest, at 200-700 m altitude.

Distribution. Brazil (Amapá, Pará), Fr. Guiana, Suriname.

Pouteria speciosa (Ducke) Baehni fig. 1

pajurá (de Obidos) (B) PI. 22,

Leaves clustered, coriaceous, glabrous, with 14-20 pairs of secondary veins. Fascicles axillary and below the leaves, 2-3-flowered, flowers bisexual, sepals $0.7-1.2 \mathrm{~cm}$ long, densely puberulous; pedicels $0.1-0.2 \mathrm{~cm}$ long, densely ferruginous-puberulous. Fruit ovoid-oblong to globose, $10-12 \times 7-8$ $\mathrm{cm}$, purplish-brown velutinous, glabrescent, pulp light yellow, granular, sweet tasting, strongly scented; seeds 1, ovoid or ellipsoid, $6-9 \times 5-6 \mathrm{~cm}$, base and apex rounded or truncate, testa bony, scar strongly rugose, covering almost the entire seed leaving a narrow, shining abaxial strip.

Notes. Tree to $45 \mathrm{~m}$ high and 90 $\mathrm{cm}$ diam., trunk slightly fluted at base, bark thick, yellowish-brown, scaling, slash dull pink, exuding little white latex; lowland rain and savanna forest on non-flooded land to $500 \mathrm{~m}$ altitude.

Distribution. Brazil (Pará, N of Obidos), Am Colombia, Guianas. 

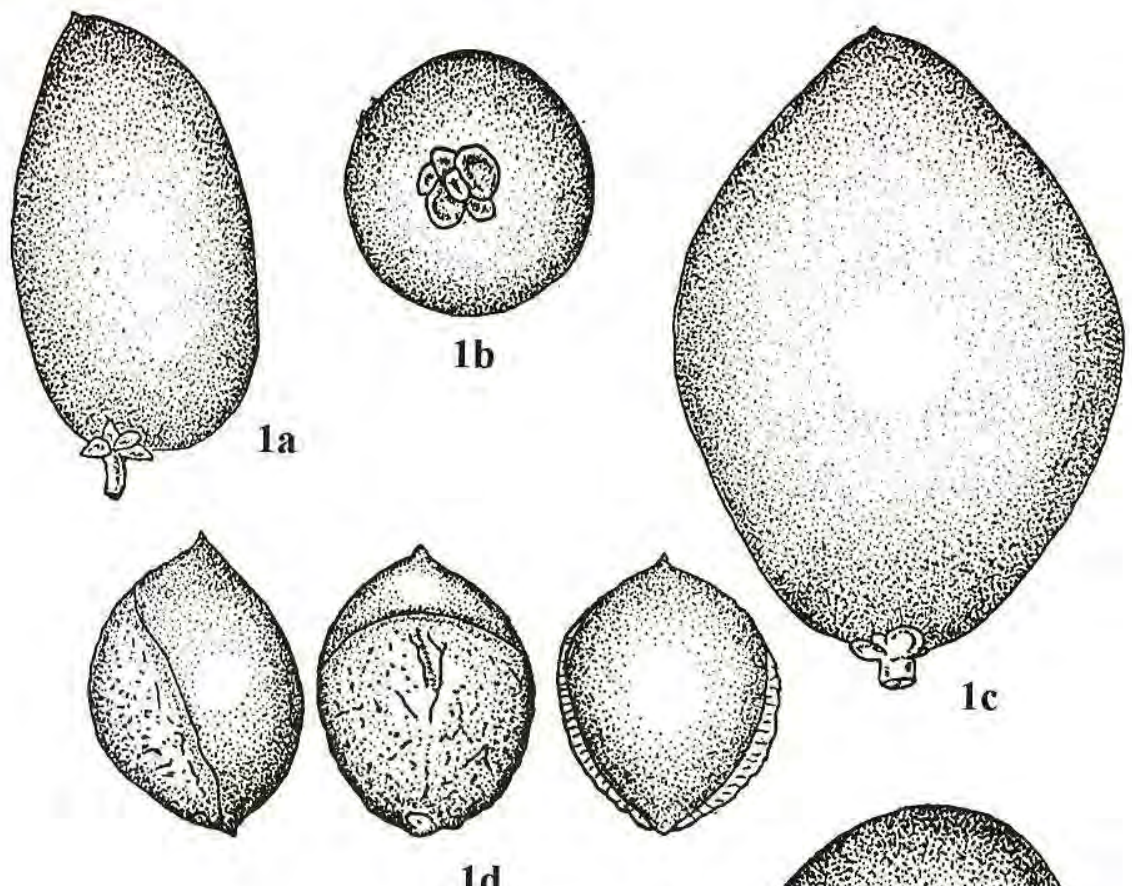

1d

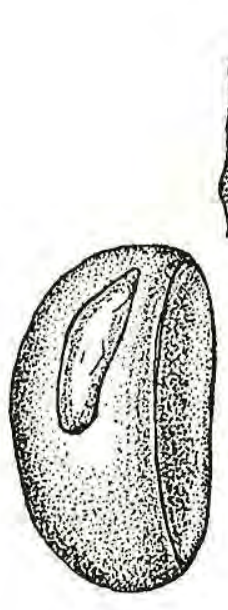

$2 c$

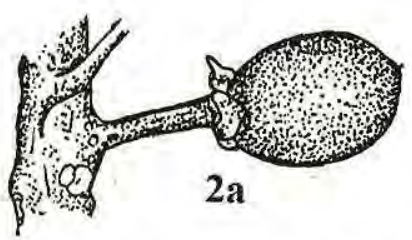

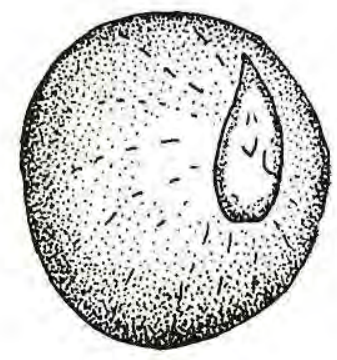

$2 c$

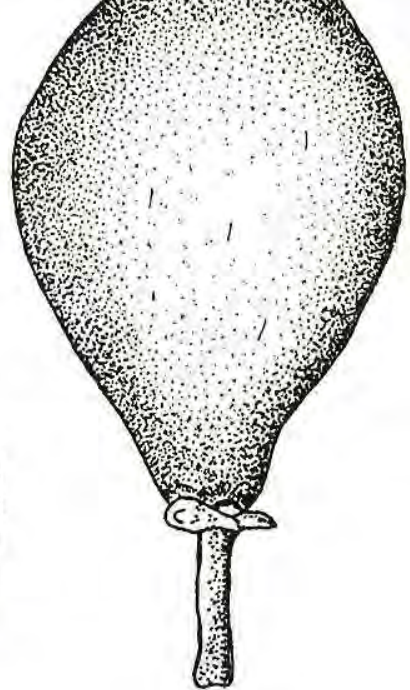

2b

PI. 21. Figs. 1-2. SAPOTACEAE. 1. Pouteria macrophylla, a. young fruit; b. young fruit from below; c. ripe fruit; d. seed, lateral and frontal views (Egler 450). 2. P. manaosensis, young fruit; b, ripe fruit; c. seed, lateral and frontal view (Van Roosmalen 134, 135). 


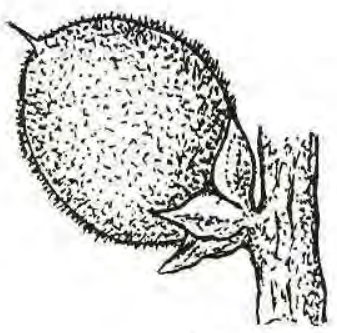

1a
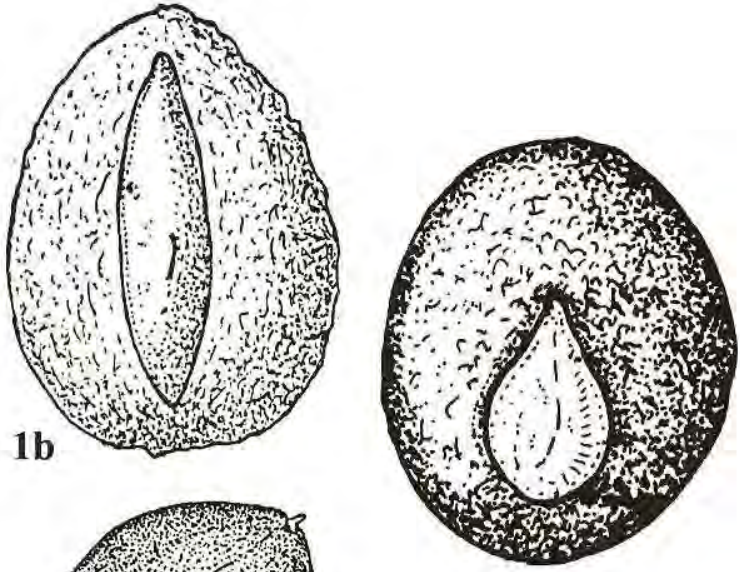

$2 \mathrm{e}$

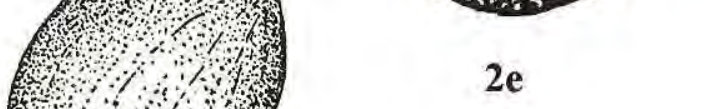

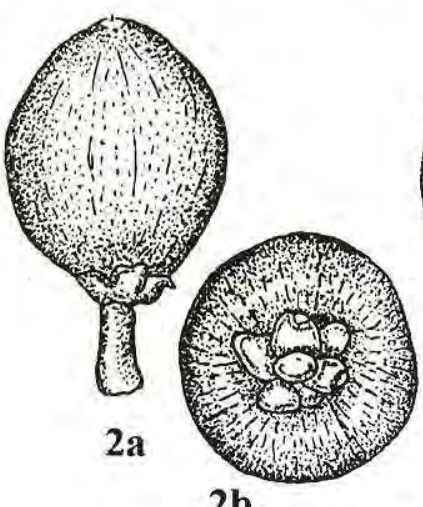
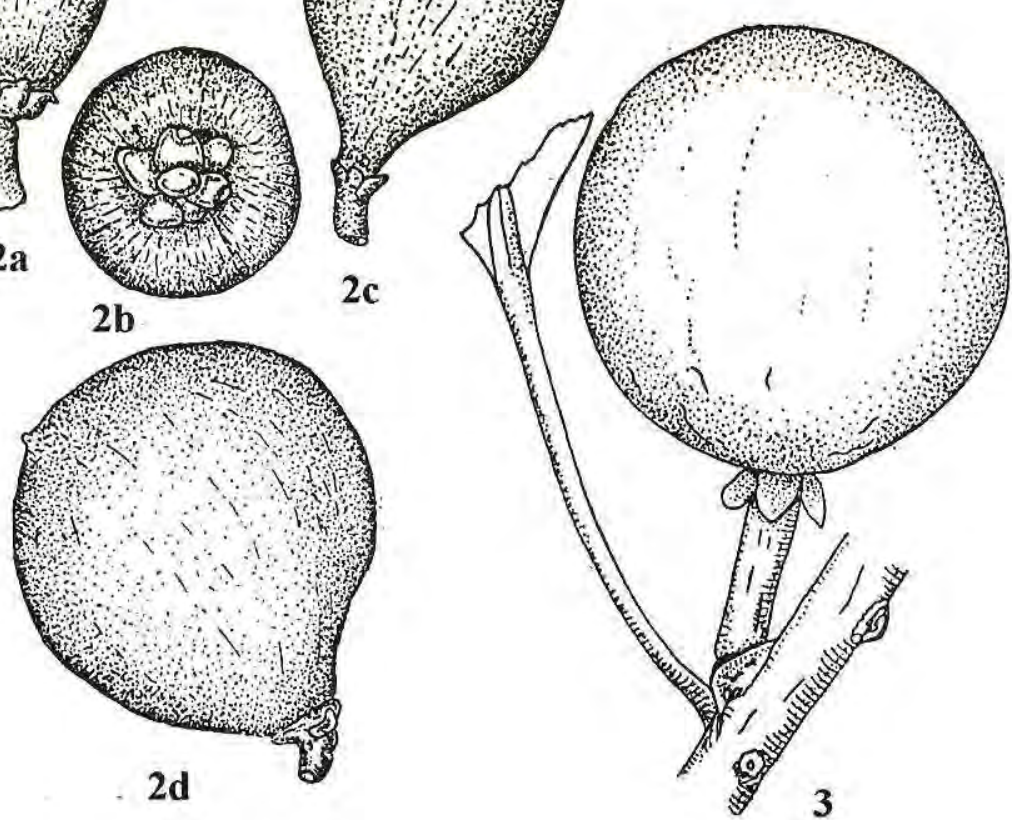

PI. 22. Figs. 1-3. SAPOTACEAE, 1. Pouteria speciosa, a. young fruit; $b$. seed, frontal view (Silva \& Santos 4752; Feuillet s.n.). 2. P. surumuensis, a. young fruit; b. young fruit from below; c. young fruit; d. ripe fruit; e. seed (Pontes 56). 3. P. grandis, fruit (Van Roosmalen S654). 


\section{Pouteria trigonosperma Eyma}

kamahora (A); mabi-jari, sabana-djoebortri (S) Pl. 23, fig. 1

Leaves thinly coriaceous, glabrous, with 6-8 pairs of secondary veins, petioles $2-4.6 \mathrm{~cm}$ long, strongly channelled. Fascicles mostly below the leaves, 1-3-flowered, flowers bisexual, sepals $1-1.5 \mathrm{~cm}$ long, inner pair exceeding the outer sepals, appressed puberulous; pedicels $1.2-2 \mathrm{~cm}$, in fruit to $2.6 \mathrm{~cm}$ long, reddish-ferruginous puberulous. Fruit subglobose to broadly ovoid, $4.5 \times 6 \mathrm{~cm}$ to $7 \mathrm{~cm}$ diam., apex obtuse, sometimes obtusely acuminate, base truncate, maturing green, smooth, glabrous, pulp soft, dry, pale yellow with apple odor; seeds (5-)7-8, trigonous, shaped like the segment of an orange, testa dark brown, smooth, shining, scar covering the two radial sides and base of the seed.

Notes. Tree to $40 \mathrm{~m}$ high and 65 $\mathrm{cm}$ diam., slash exuding thick white latex; lowland rain and savanna forest (in Guyana in forest dominated by 'greenheart' (Ocotea rodiaei).

\section{Distribution. Guyana,}

\section{Suriname.}

Pouteria venosa (Martius) Baehni subsp. amazonica

kamahora (A); jaboka (S); pakuku(P); abiurana-grande/preta, cutitiriba-rana, guajara (B) Pl. 23, fig. 2

Leaves chartaceous, glabrous, with 8-14 pairs of secondary veins. Fascicles axillary and below the leaves, 1-6-flowered, flowers bisexual, sepals $0.3-1(-1.5) \mathrm{cm}$ long, inner pair often longer than outer one, appressed puberulous or pubescent; pedicels 0.4-
$2.2 \mathrm{~cm}$, in fruit to $3 \mathrm{~cm}$ long, appressed puberulous or crisped pubescent. Fruit (depressed) globose, $4-8 \mathrm{~cm}$ long and to $6 \mathrm{~cm}$ diam., at first green, maturing orange or yellow, smooth, rufous-brown velutinous, glabrescent or with some velutinous indumentum persisting at maturity, pulp pale orange or yellow, mealy or greasy tasting; seeds $1-3$, globose, ellipsoid, or plano-convex depending on number of seeds per fruit, testa smooth, shining, scar covering up to two-thirds of the surface depending on the number of seeds, the cut seed smells strongly of almonds.

Notes. Shrub or tree to $40 \mathrm{~m}$ high and $90 \mathrm{~cm}$ diam., often with low buttresses and toward the base fluted trunk, bark dark brown or black, scaling in small flakes, slash pink, soft, laminated, exuding copious white latex; savanna forest dominated by 'wallaba' (Eperua), and lowland rain forest, especially on slopes up to $1,200 \mathrm{~m}$ altitude.

Distribution. Am and E coastal Brazil (Amapá, Amazonas, Pará, Roraima), Guianas, $\mathrm{C}$ and S Venezuela.

\section{Pouteria Section 6. Pouteria}

Leaves with usually oblique or horizontal tertiary venation, sometimes reticulate. Calyx 4-merous, (4)5-merous only in Pouteria pariry. Seeds broadly ellipsoid, shaped like the segment of an orange, plano-convex or sometimes laterally compressed, scar adaxial, usually broad (often covering most of the seed surface), sometimes narrow.

Pouteria amapaensis Pires \& Pennington

Leaves clustered, chartaceous or 
thinly coriaceous, silvery puberulous below, with 8-13 pairs of secondary veins. Fascicles axillary and below the leaves, 1-2-flowered, sepals $4,0.4 \mathrm{~cm}$ long, minutely puberulous; pedicels ca. $0.1 \mathrm{~cm}$ long, appressed puberulous. Fruit unknown.

Notes. Small tree to $2 \mathrm{~m}$ high; terra-firme rain forest.

Distribution. Brazil (Amapá, only once collected along $\mathrm{R}$. Araguari).

Pouteria caimito (Ruiz \& Pavón) Radlkofer

asepokoballi (A); ingi-oedoe (S); pepeboiti (P); abiú, abiurana (B) Pl. 23 , fig. 3

Leaves chartaceous, glabrous, rarely pubescent, with 8-13(-16) pairs of secondary veins. Fascicles axillary and below the leaves, sometimes densely clustered, 1-3(-5)-flowered, flowers bisexual, sepals $4,0.3-0.5 \mathrm{~cm}$ long, partly strigose outside; pedicels $0-0.2 \mathrm{~cm}$ long, puberulous to glabrous. Fruit narrowly ellipsoid, ovoid or globose, $2.7-7.5 \times 3.8-4.3 \mathrm{~cm}$, apex acute to rounded, base rounded to truncate, maturing yellow or orange, smooth, pubescent or velutinous, often glabrous in cultivated specimens, pericarp uniformly soft with a seed that is easily detached from the whitish translucent pulp in cultivated specimens, whereas fruits from western Amazonian plants often show a very hard, almost woody outer pericarp, which softens toward the interior, and the innermost $0.1-0.2 \mathrm{~cm}$ are gelatinous and strongly adherent to the seed; seeds 1-4(-5), oblong to ellipsoid, 1.8$2 \times 0.9-1 \mathrm{~cm}$, sometimes up to $5 \mathrm{~cm}$ long, often slightly laterally compressed, base and apex rounded or obtuse, testa smooth, shining, scar full-length, $0.1-0.6 \mathrm{~cm}$ wide, broader in cultivated specimens.

Notes. Tree to $30 \mathrm{~m}$ high and 50 $\mathrm{cm}$ diam., trunk of older specimens fluted, bark dark reddish-brown to greyish-brown, scaling and shallowly fissured, slash cream, exuding white latex; because of extensive cultivation for its delicious fruits, the natural distribution is uncertain; Peres (1994) saw Geoffroy's woolly monkeys (Lagothrix lagotricha cana) feeding on the mature pulp, swallowing and endochorically dispersing the large seeds; this species occurs especially on periodically flooded land in lowland rain forest, seasonal evergreen rain forest, and in wet montane forest, at altitudes from sea level (restinga) to $1,500 \mathrm{~m}$.

Distribution. Bolivia, Brazil (Acre, Amapá, Amazonas, Pará, Rondônia, Roraima), Colombia, Ecuador, Guianas, Venezuela.

\section{Pouteria cicatricata Pennington} Fig. 4

abiurana-folha-larga (B) Pl. 23,

Leaves spaced, chartaceous, densely silvery-brown short-pubescent below, with 15-20 pairs of secondary veins. Fascicles axillary and below the leaves, 1-2-flowered, sepals 4, lanceolate, $0.5-0.6 \mathrm{~cm}$ long, outer pair short-pubescent outside; fruits sessile. Fruit globose, 3-3.5 cm diam., apex shortly rostrate, base truncate, when dry slightly verruculose, densely shorttomentose or -pubescent; seeds 2, oblong-ellipsoid, ca. $2.2 \mathrm{~cm}$ long, plano- 
convex, both ends rounded, scar area rough and verruculose, covering most of the seed, leaving only a lanceolate, smooth, abaxial segment which adheres to the pericarp.

Notes. Tree to $20 \mathrm{~m}$ and $20 \mathrm{~cm}$ diam., slash exuding white latex; lowland terra-firme rain forest and hill forest.

Distribution. Am Brazil, south of Rio Amazonas (Amazonas, Rondônia).

\section{Pouteria decorticans Pennington} Fig. 5

abiú giboia, abiurana (B) Pl. 23,

Leaves clustered, spirally arranged, chartaceous or thinly coriaceous, below with fine white closely appressed hairs, with 13-20 pairs of secondary veins. Fascicles clustered below the leaves, 1-3-flowered, flowers sessile, bisexual; sepals 4, 0.6-0.7 cm long, with stiff, closely appressed hairs. Fruit narrowly ovoid or ellipsoid, $3-3.5 \mathrm{~cm}$ long, apex acute, base rounded, at maturity yellow or pale orange, smooth, appressed white-puberulous, pericarp tough, containing edible white pulp; seeds several, oblong or ellipsoid, 1.8$2 \mathrm{~cm}$ long, often plano-convex, both ends rounded or obtuse, testa smooth, shining, scar adaxial and extending around the base, ca. $0.2 \mathrm{~cm}$ wide.

Notes. Tree to $25 \mathrm{~m}$ high and 35 $\mathrm{cm}$ diam., without or with small, simple or branched, up to $50 \mathrm{~cm}$ high buttresses, trunk fluted, bark (reddish)brown, peeling profusely in thin large papery pieces, slash $0.2 \mathrm{~cm}$ thick, orange, pink or cream, exuding sticky white latex; seasonal semi-evergreen terra-firme forest up to $500 \mathrm{~m}$ altitude.
Distribution. Am Brazil (Amapá, Amazonas), Fr. Guiana, Venezuela (Mérida).

\section{Pouteria deliciosa Pennington PI.}

$$
\text { 24, fig. } 1
$$

Leaves clustered, spirally arranged, thinly coriaceous, glabrous, with 13-15 pairs of secondary veins. Fascicles axillary and below the leaves, 3-5-flowered, sepals $4,0.5 \mathrm{~cm}$ long, puberulous; pedicels $0.1-0.2 \mathrm{~cm}$ long, puberulous. Fruit ellipsoid, 5.5$8 \mathrm{~cm}$ long, rounded at the ends, pericarp hard, smooth, minutely appressed puberulous, glabrescent; seeds several, ellipsoid, rounded at the ends, sometimes slightly laterally compressed, testa smooth, adherent to the pericarp, scar adaxial, full-length and extending around the base, rough, ca. $0.8 \mathrm{~cm}$ wide at apex, tapering to ca. $0.4 \mathrm{~cm}$ wide at base.

Notes. Tree to $25 \mathrm{~m}$ high, with short, to 2-3 $\mathrm{m}$ high buttresses, bark (yellow-)brown, peeling in small pieces; lowland rain forest up to $250 \mathrm{~m}$ altitude.

Distribution. Am Colombia, Fr. Guiana, Am Peru.

\section{Pouteria filipes Eyma}

kamahora (A); abiurana (B); zwarte jamboka (S) Pl. 24, fig. 2

Leaves spaced or loosely clustered, spirally arranged, chartaceous or coriaceous, pale golden to reddishbrown appressed puberulous or sericeous below, with $10-15$ pairs of secondary veins. Fascicles axillary and below the leaves, sometimes in dense clusters, 2-15-flowered, flowers unisexual, sepals $4,0.2 \mathrm{~cm}$ long, appressed puberulous; pedicels $0.2-0.7$ 

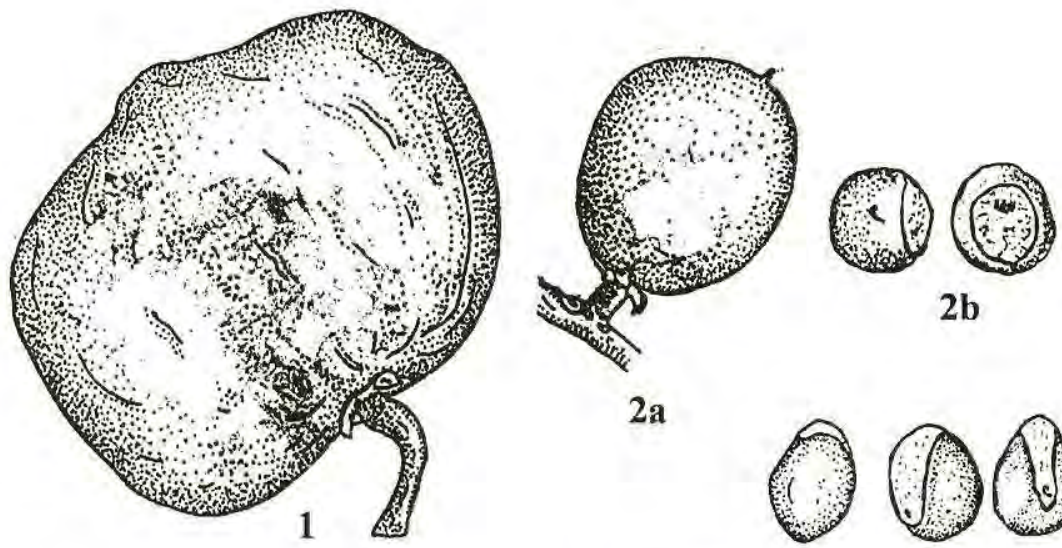

2b
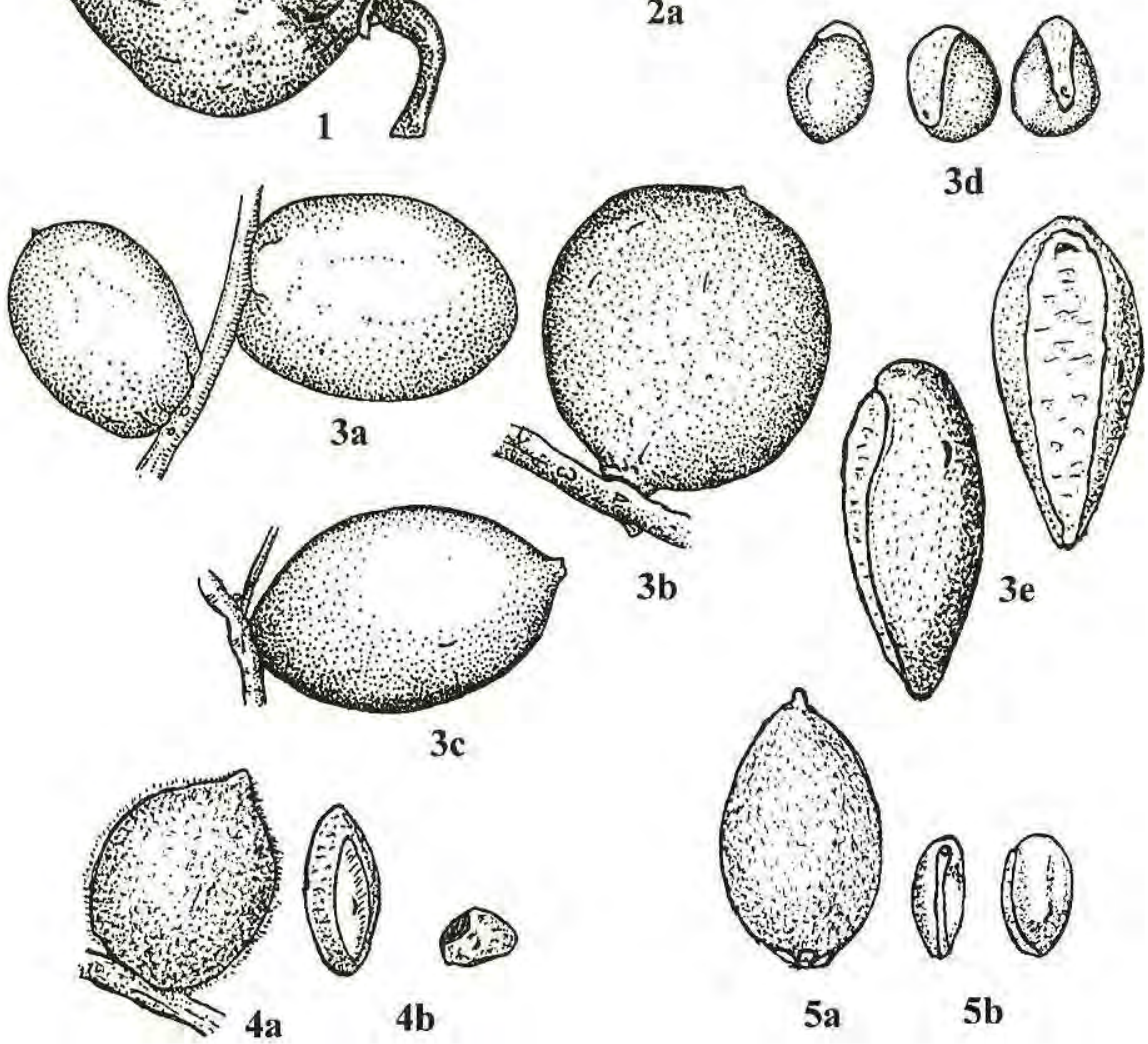

PI. 23. Figs. 1-5. SAPOTACEAE. 1. Pouteria trigonosperma, fruit (Van Roosmalen S704). 2. $P$. venosa subsp. amazonica, a. fruit; b. seed, lateral and frontal view (Van Roosmalen S634; Reitz 3575). 3. P. caimito, a. infructescence; b. fruit; c; fruit; $d$. seed, lateral and frontal views; e. larger seed, lateral and frontal view (Van Roosmalen S245, 115; Pennington 10672). 4. P. cicatricata, a. fruit; b. seed, frontal and lateral view (Krukoff 6793). 5. P. decorticans, a. fruit; b. seed, frontal and lateral view (Mori \& Pipoly 15409). 
$\mathrm{cm}$ long, appressed puberulous. Fruit ellipsoid, stipitate, $4.5-5 \mathrm{~cm}$ long (not including the ca. $2 \mathrm{~cm}$ long, stout stipe), apex obtuse or rounded, base tapering over ca. $2 \mathrm{~cm}$, smooth, glabrous or minutely papillose; seeds 2 , ellipsoid, $3-3.2 \mathrm{~cm}$ long, testa woody, scar covering most of the seed surface.

Notes. Tree to $40 \mathrm{~m}$ high and 1.2 $\mathrm{m}$ diam., with large, up to $5 \mathrm{~m}$ high buttresses, slash exuding sparse white latex; rain forest on hillsides up to $1,000 \mathrm{~m}$ altitude.

Distribution. NE Brazil (Amapá, Pará, Roraima), Guianas, N Venezuela.

\section{Pouteria fimbriata Baehni}

kamahora (A); abiurana-ferro (B) Pl. 24, fig. 3

Leaves loosely clustered, spirally arranged, chartaceous, glabrous, with 811 pairs of secondary veins. Fascicles axillary and below the leaves, 2-5-flowered, sepals $4,0.1-0.3 \mathrm{~cm}$ long, puberulous; pedicels $0.1-0.4 \mathrm{~cm}$ long, sparsely appressed puberulous. Fruit broadly obovoid, $2.7 \times 1.4$ to $3.7 \times 2.2$ $\mathrm{cm}$, sometimes to $4.7 \times 4 \mathrm{~cm}$, or subglobose to $5.5 \times 5 \mathrm{~cm}$, apex rounded, base often tapering to a short stout, ca. $0.5 \mathrm{~cm}$ long stipe, maturing yellow, smooth or rugulose, glabrous or with some brown puberulous indumentum, fleshy; seeds 1-3, oblong-ellipsoid, 2-2.8 x 1.3-1.4 x 1.2-1.3 cm, slightly planoconvex, rounded at the ends, testa woody, hard, smooth, adherent to the pericarp, scar adaxial, often extending around the base, ca. $0.6 \mathrm{~cm}$ wide near the apex, tapering toward the base, dull, verruculose.

Notes. Tree to $30 \mathrm{~m}$ high and 40 $\mathrm{cm}$ diam., with to $1 \mathrm{~m}$ high buttresses, slash exuding white latex; in the rain forest $80 \mathrm{~km}$ north of Manaus, Amazonas, Brazil, the immature seeds are heavily predated upon by black bearded sakis (Chiropotes satanas chiropotes) (Frazão, 1992) and golden-faced sakis (Pithecia pithecia chrysocephala) (Setz, 1993), whereas Peres (pers. comm.) observed buffy sakis (Pithecia albicans) and brown capuchin monkeys (Cebus apella) predating on the immature seeds in the R. Urucú region, and Geoffroy's woolly monkeys (Lagothrix lagotricha cana) (Peres, 1994) feeding on the ripe pulp; terra-firme rain and savanna forest to $1,250 \mathrm{~m}$ altitude.

Distribution. C Am Brazil (Amazonas), Guyana, S Venezuela.

\section{Pouteria franciscana Baehni} abiurana (B) Pl. 25, fig. 1

Leaves clustered, spirally arranged, chartaceous, glabrous, with 11-13 pairs of secondary veins. Fascicles mostly below the leaves, often clustered, 3-8-flowered, sepals 4 , ca. $0.4 \mathrm{~cm}$ long, the outer sepals shorter than the inner, appressed puberulous; pedicels $0.6-0.7 \mathrm{~cm}$ long, appressed puberulous. Fruit 5-6 cm diam.; seeds ca. $2.8 \mathrm{~cm}$ long, shaped like a broad segment of an orange, scar ca. $2 \mathrm{~cm}$ wide.

Notes. Tree to $30 \mathrm{~m}$ high and 50 $\mathrm{cm}$ diam., slash exuding white latex; periodically white-water flooded (várzea) forest.

Distribution. Am Brazil (Acre, Amazonas, Pará).

Pouteria glomerata (Miquel) Radlkofer

Leaves clustered at the apex, spirally arranged, chartaceous, yellowish- 

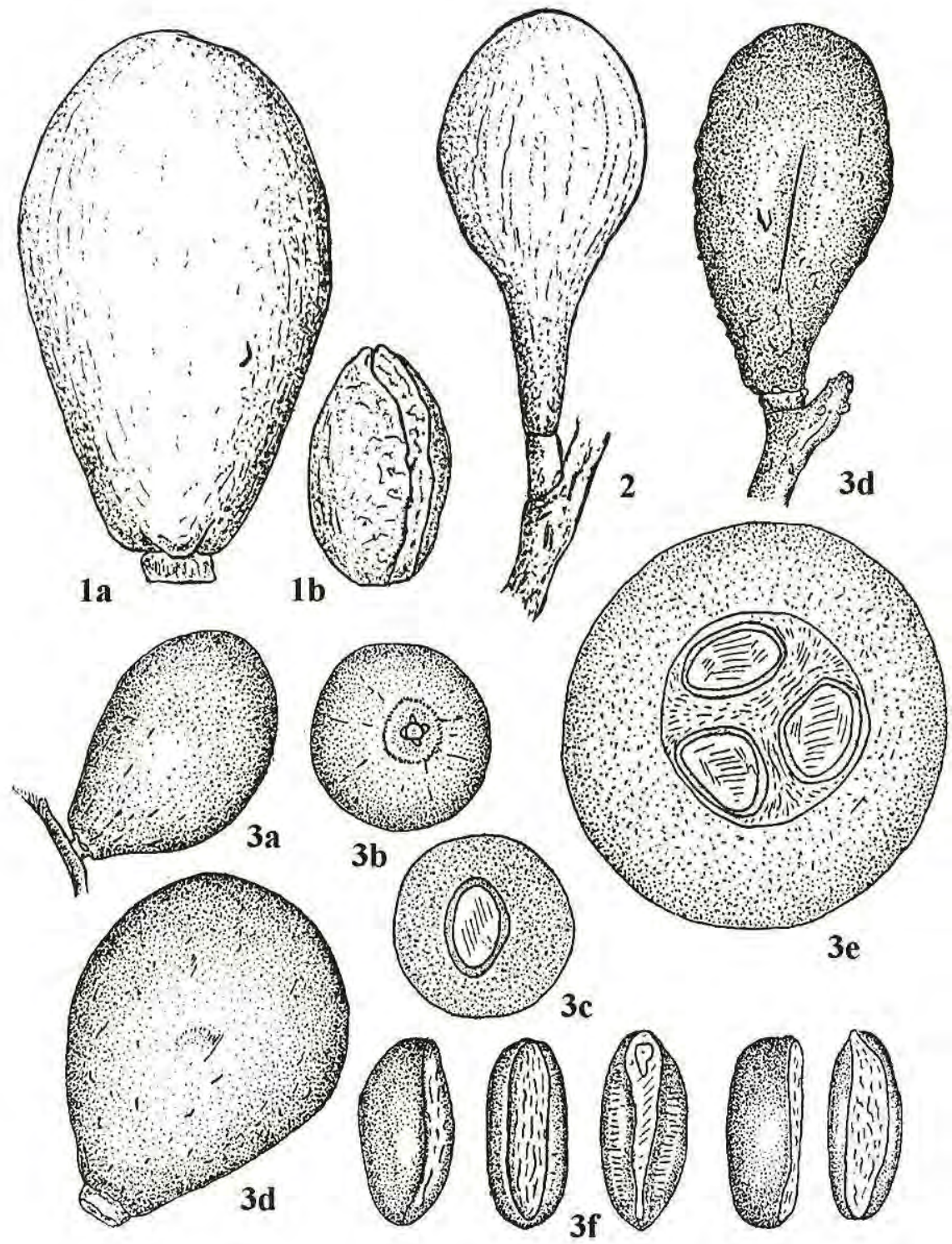

PI. 24. Figs. 1-3. SAPOTACEAE. 1. Pouteria deliciosa, a. fruit; b. seed (Sabatier 1213). 2. P. filipes, fruit (Steyermark \& Liesner 120748). 3. P. fimbriata, a, fruit; b. fruit from below; c. cross section of 1 -seeded fruit; $d$. fruit; e. cross section of 3 -seeded fruit; $f$. seed, lateral and frontal views (Van Roosmalen 125, 126, 127, 132, 133). 
sericeous or white-puberulous below, with $10-17(-19)$ pairs of secondary veins. Fascicles axillary and below the leaves, 2-10-flowered, flowers unisexual, sepals 4, 0.2-0.4 cm long, appressed puberulous outside; pedicels to $0.1 \mathrm{~cm}$ long, appressed puberulous. Fruit globose or depressed globose, often broader than long, $2.5-9 \mathrm{~cm}$ long, sometimes very irregular and knobbly, truncate at the ends, , smooth or rough, glabrous or with some scurfy indumentum near the base; seeds 1-4, broadly ellipsoid or plano-convex (when more than one), testa woody, smooth, shining, reduced to a small abaxial segment, scar covering most of the seed, often verrucose.

\section{Pouteria glomerata (Miquel)}

Radlkofer subsp. glomerata

abiú, abiurana-abiú, abiurana-deigapó, abiurana-de-várzea, coquiranagogo, guajará (B); pepe-boiti (P) $\mathbf{P l}$. 25 , fig. 2

Leaves minutely puberulous below with closely appressed white hairs, forming a pellicle, subglabrescent with age. Fruit transversely ellipsoid, $2.7-3 \mathrm{x}$ $3.7 \times 3.5 \mathrm{~cm}$ to $3.8 \times 5 \times 4.5 \mathrm{~cm}$, sometimes to $7 \mathrm{~cm}$ diam., sometimes tetrangular (when containing 4 seeds), maturing yellowish to greyish-brown, pulp yellow, soft, fibrous, at first containing white sticky latex, pulp edible, extremely sour-tasting; seeds angulate, $3 \times 2 \times 1.5 \mathrm{~cm}$, with two plane and one convex side, testa on convex side, dropshaped, $2.2 \times 1.2 \mathrm{~cm}$.

Notes. Tree to $30 \mathrm{~m}$ high, flowering and fruiting already when less than $10 \mathrm{~m}$ high and throughout the year, slash exuding sticky white latex; fruits float 7-29 days, till the pericarp falls off and the seeds sink; seed dispersal by water (hydrochory) and by fish (ichtyochory), in particular 'tambaqui' (Colossoma macropomum), of which only the larger (weighing in over $10 \mathrm{~kg}$ ) specimens do not destroy the seeds (Ziburski, 1990); where howling monkeys (Alouatta seniculus and A. belzebul) still occur in flooded forests, the seeds are probably also dispersed endozoochorically by these monkeys; riverbank forest and on periodically or permanently flooded land, rarely in terra-firme rain forest up to $1,300 \mathrm{~m}$ altitude.

Distribution. Throughout tropical S America; Brazil (Acre, Amazonas, Mato Grosso, Pará, Rondônia), Colombia, Ecuador, Fr. Guiana, Peru, Venezuela.

\section{Pouteria glomerata (Miquel)}

Radlkofer subsp. stylosa (Pierre)

Pennington Pl. 25, fig. 3

Leaves persistently sericeous below, with a yellowish-buff indumentum.

Notes. Tree to $25 \mathrm{~m}$ high and 50 $\mathrm{cm}$ diam., bole fluted, bark greyishwhite or greyish-brown, finely fissured, slash straw-coloured, exuding white latex; periodically white-water flooded (várzea) forest and permanently blackwater flooded (igapó) forest.

Distribution. Am Brazil (Acre, Amazonas, Pará), Venezuela, C America.

Pouteria gomphiifolia (Martius)

Radlkofer

abiurana-de-baixo/do igapó/ maparajuba/streita, maçaranduba (B)

Pl. 25, fig. 4 
Leaves spaced or loosely clustered, spirally arranged, chartaceous, glabrous, with 20-35 pairs of secondary veins. Fascicles axillary and below the leaves, 3-10-flowered, flowers unisexual, sepals 4 , ca. $0.3 \mathrm{~cm}$ long; pedicels $0.3-0.4 \mathrm{~cm}$ long. Fruit obovoid or ellipsoid, $4.5 \times 2.5-2.8 \mathrm{~cm}$ to $6 \times 3.4 \times 3 \mathrm{~cm}$, apex obtuse or rounded, apiculate, base tapering over $0.5 \mathrm{~cm}$, green to yellow or orange, smooth, with a ferruginous indumentum, glabrescent, pulp white, transparant, edible, sweet-tasting; seeds $1(-3)$, ellipsoid, $3.2-4 \times 1.2 \times 1$ $\mathrm{cm}$, laterally compressed, apex rounded, base acute, testa brown, smooth, shining, scar adaxial, 0.4-0.5 $\mathrm{cm}$ wide, dull brown.

Notes. Tree to $30 \mathrm{~m}$ high and 80 $\mathrm{cm}$ diam., with up to $1 \mathrm{~m}$ high buttresses, bark scaling, slash brown, exuding copious white latex; seeds both dispersed by fish (ichtyochory) and monkeys (endozoochory), such as howling monkeys (Alouatta spp.); along Lago Tefé, Amazonas, Brazil, the author saw buffy sakis (Pithecia albicans) feeding on the mature pulp; seasonally white-water flooded (várzea) and permanently black-water flooded (igapó) forest to $250 \mathrm{~m}$ altitude, sometimes in terra-firme rain forest over sand along creeks.

Distribution. Am Brazil (Amazonas, Roraima), Am Colombia, Am Peru, Am Venezuela.

\section{Pouteria guianensis Aublet}

asipoko, kamahora

(A); jansnijder (SD); redi-jamboka, asepoko (S); pepeboiti (P); abiú, abiurana abiú/casca-fina/gigante/sabia, coquirana-caranazal, gutta percha (B) Pl. 26, fig. 1

Leaves clustered, spirally arranged, coriaceous, minutely brownish sericeous below or glabrous, with 1322 pairs of secondary veins. Fascicles axillary and below the leaves, 2-5(10)-flowered, flowers bisexual, sepals 4, $0.3-1 \mathrm{~cm}$ long, brown puberulous to sericeous; pedicels $0.1-0.6 \mathrm{~cm}$ long, appressed brown puberulous, in fruit to $0.6 \mathrm{~cm}$ long. Fruit globose or broadly ellipsoid, $4.5-5 \times 4-5.3 \mathrm{~cm}$, sometimes to $7 \mathrm{~cm}$ long, rounded or truncate at base and apex, dark green to yellow, maturing orange-yellow, smooth (or sometimes verrucose), at first tomentose or appressed puberulous, glabrescent, pulp firm, edible, sweet-tasting; seeds $2(-4)$, depressed-ellipsoid or plano-convex, 1.7 $\times 1.3 \times 1.1$ to $2.5(-3.3) \times 1.8 \times 1.4 \mathrm{~cm}$, rounded at the ends, testa hard, smooth, shining, scar broad, adaxial and often extending around the base, $0.6-1.1 \mathrm{~cm}$ wide.

Notes. Tree to $40 \mathrm{~m}$ high and 90 $\mathrm{cm}$ diam., with steep, slender buttresses or trunk strongly fluted from base, bole usually fluted above, bark reddish brown, with fine vertical cracks or fissures, scaling in long thin strips, slash pale brown or cream, exuding sticky white latex, wood red; in Suriname and N Brazil, black bearded sakis (Chiropotes satanas chiropotes) (Frazão, 1992) were seen predating on the immature seeds of this species, whereas red-faced black spider monkeys (Ateles paniscus) swallowed the ripe pulp together with the seeds and dispersed the seeds endochorically; 


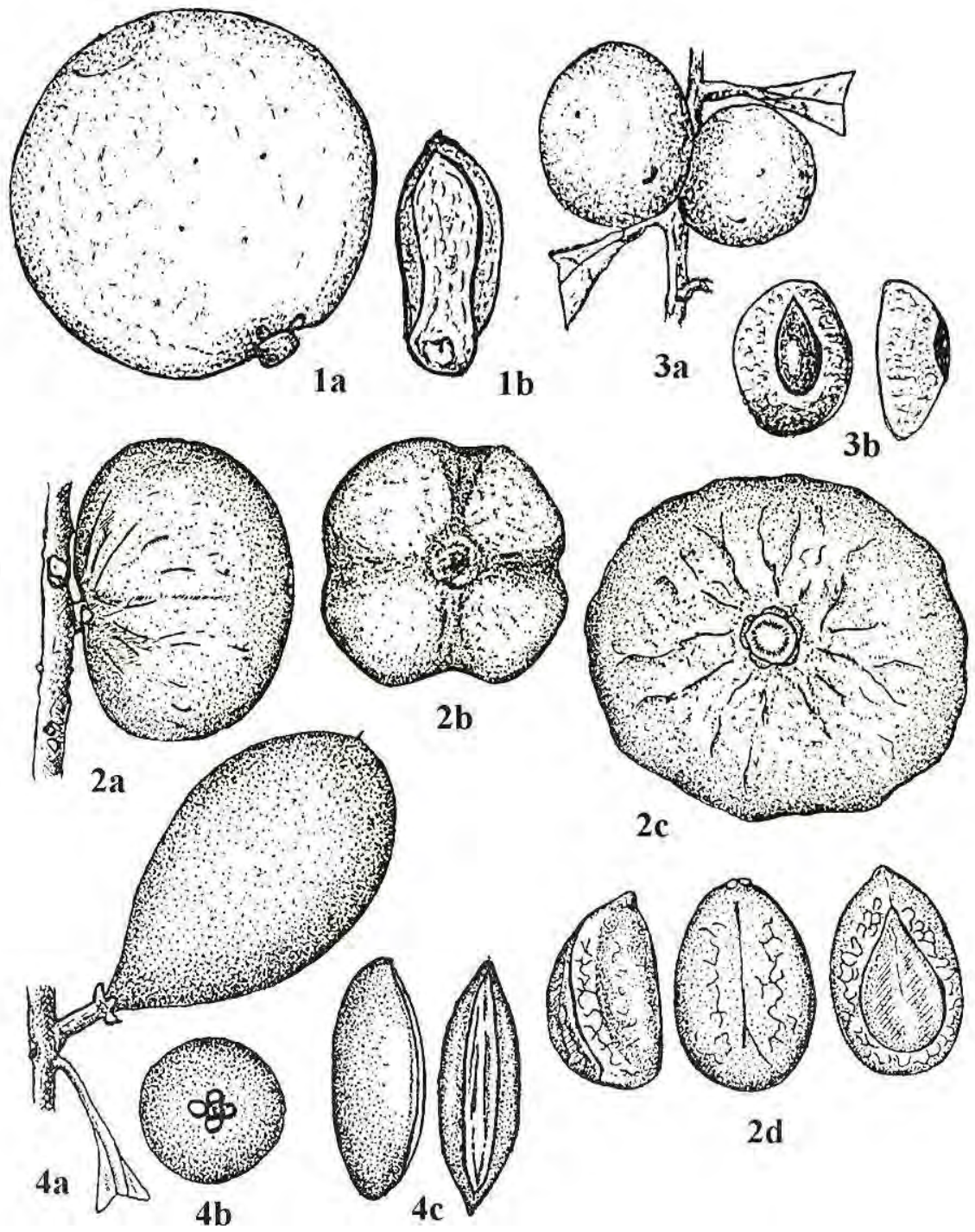

PI. 25. Figs. 1-4. SAPOTACEAE. 1. Pouteria franciscana, a. fruit; b. seed (Van Roosmalen 174). 2. P. glomerata subsp. glomerata, a. fruit; b. fruit from below; c. larger fruit from below; d. secd, lateral and frontal view (Van Roosmalen 116, 117). 3. P. glomerata subsp. stylosa, a. infructescenee; b. seed, frontal and lateral view (Davidse et al. 18222; Pennington \& Poveda 11553). 4. P. gomphiifolia, a. fruit; b. fruit from below; c. seed, lateral and frontal view (Van Roosmalen 130b). 
terra-firme rain forest, also found in wet montane and cloud forest to 2,500 $m$ altitude.

Distribution. Am Bolivia, Colombia, Am Brazil (Amapá, Amazonas, Pará, Rondônia), Guianas, Am Peru, Venezuela.

\section{Pouteria hispida Eyma}

asipoko, atakamaraballi, kamahorà (A); abiurana-braba/caramuri (B) PI. 26, fig. 2

Leaves clustered, spirally arranged, thinly coriaceous, sparsely villose or pubescent below, glabrescent, with 8-18 pairs of secondary veins. Fascicles densely clustered below the leaves, 2-6-flowered, flowers unisexual, sepals $4,0.2-0.4 \mathrm{~cm}$ long, sericeous(-hispid); pedicels $0-0.15 \mathrm{~cm}$ long, hispid or sericeous. Fruit broadly ovoid to globose, $2.4 \times 1.6 \mathrm{~cm}$ to 3.3 x 3.1 to $4.5 \times 4.1 \mathrm{~cm}$, sometimes to 8 $\mathrm{cm}$ long, apex obtuse to rounded, base rounded or truncate, maturing yellow or orange to red, smooth, brown pilose to densely velutinous, pulp thick, firm, with a $0.2-0.3 \mathrm{~cm}$ thick yellow juicy edible jelly surrounding the seed; seeds 1(-3), ellipsoid or plano-convex, sometimes shaped like the segments of an orange, $1.7 \times 0.9 \times 0.8 \mathrm{~cm}$ to 2.1 $2.5 \times 1.4 \times 1.2 \mathrm{~cm}$, sometimes to 3.5 $\mathrm{cm}$ long, obtuse at both ends, testa smooth, shining, scar adaxial, sometimes extending around the base, 0.2$0.4 \mathrm{~cm}$ wide, dull brown.

Notes. Tree to $35 \mathrm{~m}$ high and 1 $\mathrm{m}$ diam., with steep branched buttresses to $5 \mathrm{~m}$ high, bole usually fluted, bark dark or reddish-brown, scaling in thin irregular pieces, slash cream to pale orange or pink, exuding copious sticky white latex; goldenfaced sakis (Pithecia pithecia chrysocephala) (Setz, 1993) and black bearded sakis (Chiropotes satanas chiropotes) (Frazão, 1992) were seen predating on the immature seeds of this species north of Manaus, Am Brazil, whereas Peres (1993) observed two species of tamarin (Ávila Pires' saddle-back/Saguinus fuscicollis avilapiresi and red-cap moustached tamarin/Saguinus mystax pileatus) feeding on the ripe pulp in the R. Urucú region, Central Amazonia, Brazil, and Defler (pers. com.) saw Humboldt's woolly monkeys (Lagothrix l. lagotricha) feeding on the pulp of this species in the R. Apaporis region, Am Colombia; terrafirme rain and savanna forest up to $900 \mathrm{~m}$ altitude.

Distribution. Bolivia, Am Brazil (Amapá, Amazonas, Pará, Rondônia, Roraima), Am Colombia, Guianas, Am Peru, Venezuela.

\section{Pouteria juruana Krause}

Leaves loosely clustered, spirally arranged, , chartaceous, with 6-8 pairs of secondary veins. Fascicles axillary, 1-3flowered, sepals $4,0.2-0.35 \mathrm{~cm}$ long, sparsely and minutely appressed puberulous; pedicels ca. $0.3 \mathrm{~cm}$ long, finely appressed puberulous. Fruit not known.

Notes. Tree to $10 \mathrm{~m}$ high; lowland rain forest to $225 \mathrm{~m}$ altitude.

Distribution. Brazil (W Amazonas, only once collected), Colombia (Putumayo, a single collection).

Pouteria lucens (Martius \& Miquel) Radlkofer

abiurana (B) Pl. 27, fig. 1

Leaves thinly coriaceous, gla- 


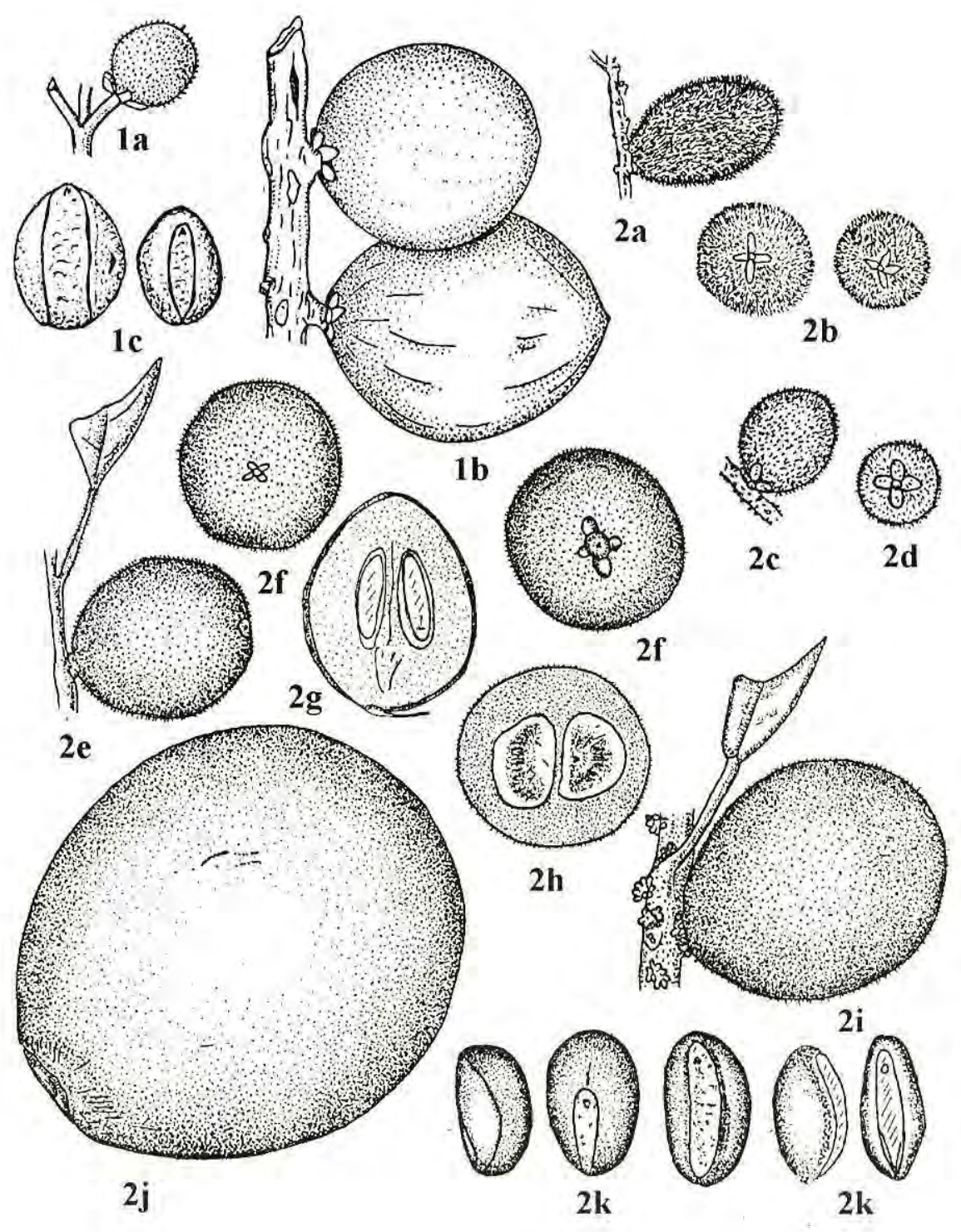

PI. 26. Figs. 1-2. SAPOTACEAE. 1. Pouteria guianensis, a. young fruit; b. infructescence; c. two types of seed, frontal view (Van Roosmalen S109; Steyermark \& Davidse 116748; De Granville 5256). 2. P. hispida, a,c,e, i and j. different fruit types; b, d,f. fruit from below; g. longitudinal section of fruit; $h$. cross section of fruit; $k$. seed, lateral and frontal views (Van Roosmalen 136, 155, 158, 159, 161, 165; Defler 236; Peres 499). 
brous, with 9-13 pairs of secondary veins. Fascicles axillary and below the leaves, 3-5-flowered, flowers unisexual, sepals 4 , ca. $0.35 \mathrm{~cm}$ long, glabrous; pedicels $0.3-0.4 \mathrm{~cm}$ long. Fruit broadly ellipsoid, ca. $5 \times 3 \mathrm{~cm}$, slightly constricted between the seeds when dry, apex obtuse, with prickle, base abruptly narrowed forming a 0.5-0.7 $\mathrm{cm}$ long stipe, smooth, subglabrous; seeds 4 , shaped like the segment of an orange, ca. $3.5 \mathrm{~cm}$ long, testa smooth, shining, scar adaxial, full-length, 0.8$1.2 \mathrm{~cm}$ wide.

Notes. Tree to $12 \mathrm{~m}$ high and 10 $\mathrm{cm}$ diam., slash exuding white latex; permanently black-water flooded (igapó) forest.

Distribution. Brazil (NW Amazonas, upper R. Negro and R. Japurá).

Pouteria macrocarpa (Martius) Dietrich 27, fig. 2

abiú-grande, abiurana (B) Pl.

Leaves densely clustered, spirally arranged, thinly coriaceous, minutely appressed whitish-puberulous below, with 19-28 pairs of secondary veins. Fascicles axillary and below the leaves, 20-30-flowered, flowers unisexual, sepals 4, 0.4-0.5 cm long, outer two appressed puberulous; pedicels ca. $0.1 \mathrm{~cm}$ long, minutely appressed puberulous, in fruit $0.2-1 \mathrm{~cm}$ long. Fruit irregularly globose or depressed globose, 3.5-6.5 x 4.3-5 cm, often broader than long, apex often with asymetrically placed firm prickle, brownish to orange when ripe, finely puberulous, glabrescent, pericarp hard, pulp yellow and edible; seeds 1-4, globose or plano-convex, $2.7 \times 2 \times 1.8 \mathrm{~cm}$ to $5 \mathrm{~cm}$ long, testa smooth, reduced to a narrow abaxial strip, testa woody, scar covering most of the seed surface, rough, dull brown.

Notes. Tree to $30 \mathrm{~m}$ and $65 \mathrm{~cm}$ diam., with fluted bole, bark scaling, slash exuding white latex; juvenile trees have terminal clusters of massive, up to $80 \mathrm{~cm}$ long leaves; lowland and montane rain forest to $1,800 \mathrm{~m}$ altitude.

Distribution. Am Brazil (Amazonas, Pará), Colombia.

\section{Pouteria maguirei (Aubréville)} Pennington Pl. 27, fig. 3

Leaves loosely clustered, spirally arranged, thinly coriaceous, glabrescent, with 6-8 pairs of secondary veins. Fascicles axillary and below the leaves, 4-6-flowered, flowers bisexual, sepals 4 , ca. $0.25 \mathrm{~cm}$ long, appressed puberulous; pedicels ca. $0.1 \mathrm{~cm}$ long, appressed puberulous. Fruit broadly ellipsoid or subglobose, $7-10 \mathrm{~cm}$ long, , apex obtuse, base with a ca. $1.5 \mathrm{~cm}$ long and $2 \mathrm{~cm}$ wide stipe (when dry), yellowish-green to rusty or mealybrown, smooth to irregularly crested, densely brown-puberulous, sometimes glossy and glabrous, pulp white or yellowish, soft, edible; seeds $2-4$, broadly ellipsoid, ca. $2.5-3.5 \mathrm{~cm}$ long, rounded at the ends, testa smooth, shining, adherent to the pericarp, scar adaxial, full-length, ca. $1.8 \mathrm{~cm}$ wide, tapering from apex to base, rough.

Notes. Tree to $20 \mathrm{~m}$ high and 20 cm diam., slash exuding white latex; permanently black-water flooded (igapó) forest to $150 \mathrm{~m}$ altitude.

Distribution. NW Brazil (Amazonas), S Venezuela. 
Pouteria pariry (Ducke) Baehni pariri (B) Pl. 27, fig. 4

Leaves loosely clustered, spirally arranged, chartaceous, glabrous, with 16-20 pairs of secondary veins. Fascicles below the leaves, 5-10-flowered, flowers bisexual, sepals (4-)5, ca. $0.3 \mathrm{~cm}$ long, puberulous; pedicels ca. $0.4 \mathrm{~cm}$ long, puberulous. Fruit depressed globose, $7.5-10 \mathrm{~cm}$ diam., green to orange when mature, scented, smooth, glabrous, pulp pale yellowish green, soft-fibrous, juicy, edible; seeds 2-3, plano-convex or shaped like the segment of an orange, $3-5 \times 3 \times 2-2.2 \mathrm{~cm}$, testa smooth, shiny, scar adaxial, covering about half the seed surface or more.

Notes. Tree to $30 \mathrm{~m}$ high and 80 $\mathrm{cm}$ diam., bark dark greyish, scaling, slash exuding white latex; sometimes cultivated for the edible fruits; lowland terra-firme rain forest.

Distribution. Am. Brazil (Amazonas, Pará, Rondônia).

\section{Pouteria petiolata Pennington}

abiurana-cutiti (B)

Leaves clustered, spirally arranged, chartaceous, subglabrous or appressed white-puberulous below, with 12-14 pairs of secondary veins. Fascicles axillary and below the leaves, sepals 4 , ca. $0.6 \mathrm{~cm}$ long, outer two appressed puberulous; pedicels 0.1-0.25 cm long, appressed brownpuberulous. Fruit not known.

Notes. Tree to $15 \mathrm{~m}$ high and 12 $\mathrm{cm}$ diam., slash exuding white latex; terra-firme rain forest over clay.

Distribution. Brazil Amazonas, N Pará).

Pouteria plicata Pennington abiurana-do-igapó/de-várzea (B)

\section{PI. 28, fig. 1}

Leaves spaced or loosely clustered, spirally arranged, chartaceous, glabrous, with (10-)13-23 pairs of secondary veins. Fascicles axillary and clustered below the leaves, 5-10-flowered, sepals 4, outer two appressed puberulous; pedicels $0-0.15 \mathrm{~cm}$ long, appressed puberulous. Fruit irregularly globose, $2-4 \mathrm{~cm}$ diam., rounded at the ends, maturing yellowish, pericarp soft and fleshy, squashing flat in drying, glabrous; seeds several, broadly ellipsoid, $1.8-2 \mathrm{~cm}$ long, sometimes tapering toward apex, testa smooth, adherent to pericarp, scar adaxial, sometimes extending around the base, $0.4-1 \mathrm{~cm}$ wide.

Notes. Tree to $30 \mathrm{~m}$ high and 40 cm diam., bark reddish-brown, scaling, slash exuding white or yellow latex; fruit reported to be consumed by fish; periodically white-water flooded (várzea) and permanently black-water flooded (igapó) forest, up to $300 \mathrm{~m}$ altitude.

Distribution. Am Bolivia, Am+NE Brazil (Amazonas, Maranhão, Mato Grosso, Pará), Am Peru, Venezuela.

\section{Pouteria singularis Pennington PI. 28, fig. 2}

Leaves clustered, spirally arranged, thiny coriaceous, glabrous, with 6-8 pairs of secondary veins. Fascicles axillary, 1(-3)-flowered, sepals 4 , ca. $0.5 \mathrm{~cm}$ long; pedicels $0.4-0.5 \mathrm{~cm}$ long, scaly. Fruit ellipsoid or narrowly obovoid, 3.5-4 x 2-2.5 cm, apex obtuse, base tapered forming a short stipe, maturing yellow, epicarp smooth, powdery-granular; seeds 1 , $2.1-2.5 \times 0.8-0.9 \times 0.6-0.7 \mathrm{~cm}$, later- 


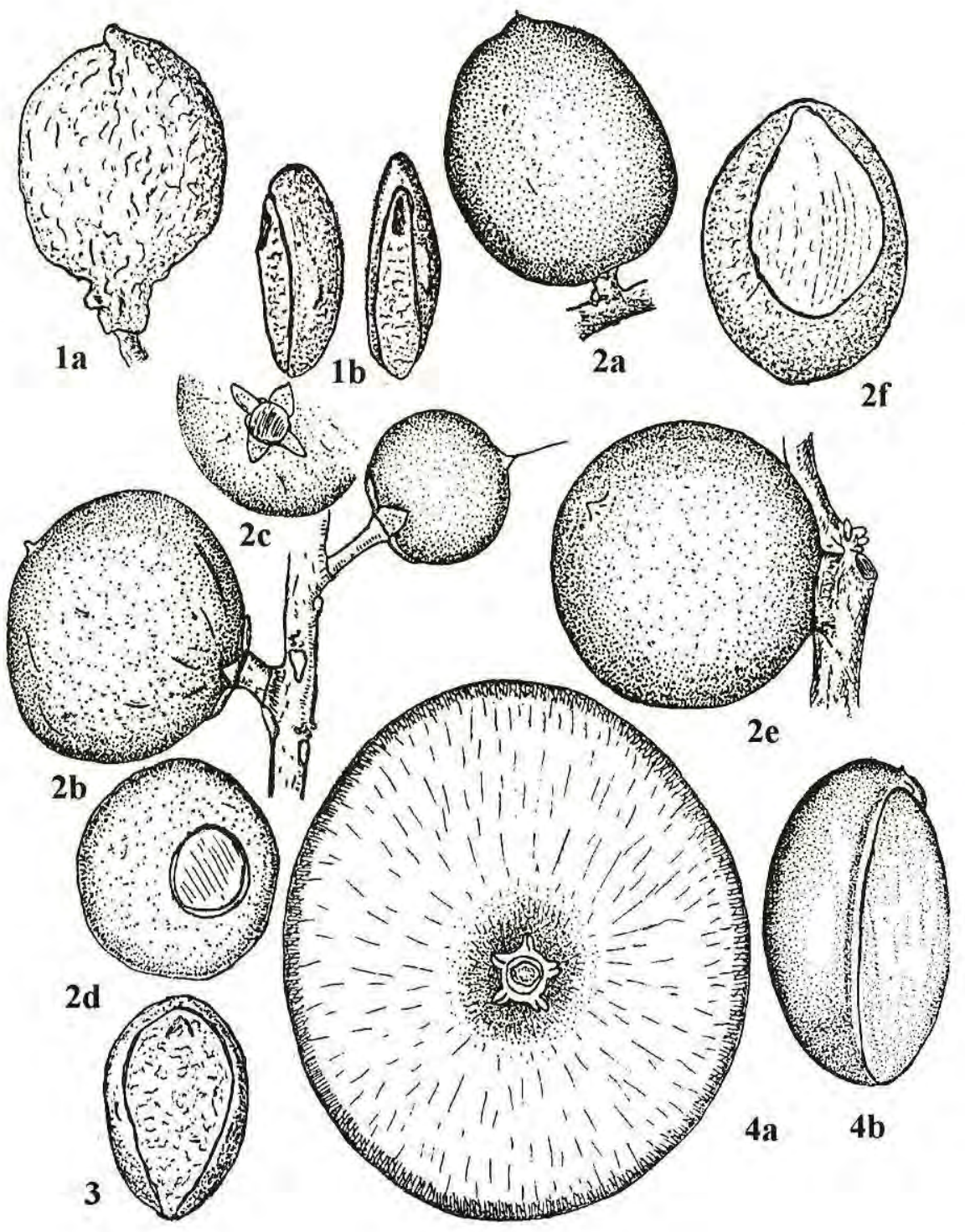

PI. 27. Figs. 1-4. SAPOTACEAE. 1. Pouteria lucens, a. fruit; b. seed, lateral and frontal view (Fróes 835A). 2. P. macrocarpa, a. fruit; b. infructescence; c. fruit from below; d. cross section of fruit; e. sessile fruit; $f$. seed, frontal view (Van Roosmalen 140, 142; Peres 561, 593; Mexia 4995). 3. P. maguirei, seed, frontal view (Guanchez 1234). 4. P. pariry, a. fruit from below; $b$. seed, lateral view (Van Roosmalen 147). 
ally compressed, base acute, testa smooth or transversely wrinkled, shiny, scar adaxial, almost full-length, unusually narrow, $0.25-0.35 \mathrm{~cm}$ wide.

Notes. Tree to $20 \mathrm{~m}$ and $40 \mathrm{~cm}$ diam., slash exuding white latex; lowland terra-firme rain forest.

Distribution. Brazil (Amapá), Fr. Guiana.

\section{Pouteria stipitata Cronquist Pl. 28,} fig. 3

Leaves loosely clustered, spirally arranged, chartaceous, glabrous, with 7-12 pairs of secondary veins. Fascicles axillary and below the leaves, 5 10-flowered, flowers unisexual, sepals $4,0.3 \mathrm{~cm}$ long; pedicels $0.15-0.3 \mathrm{~cm}$ long, appressed puberulous. Fruit obovoid or ellipsoid, 3-4 $\mathrm{cm}$ long, apex rounded, base tapered forming a short stipe, maturing yellow, smooth or slightly verrucose, the lower half covered with indumentum; seeds 1-4, broadly ellipsoid or plano-convex (when 2-seeded), testa smooth, shining, scar adaxial, elliptic, 0.7-0.9 cm wide, verruculose.

Notes. Tree to $15 \mathrm{~m}$ high and 30 $\mathrm{cm}$ diam., bark reddish-brown, shallowly fissured and flaking, slash white or pale brown, exuding white latex with an unpleasant odor; seasonal semi-evergreen forest, also in (semi-)deciduous forest, up to $200 \mathrm{~m}$ altitude.

Distribution. Panama to N Venezuela, once collected in Am Brazil (Rondônia).

\section{Pouteria tenuisepala Pires \&} Pennington Pl. 28, fig. 4

Leaves spaced or loosely clustered, spirally arranged, chartaceous, glabrous, with $10-12$ pairs of secondary veins. Fascicles axillary and below the leaves, 5-10-flowered, sepals 4, 0.3-0.4 cm long, finely appressed puberulous; pedicels $0.25-0.4 \mathrm{~cm}$ long, appressed puberulous. Fruit only examined when immature, globose, ca. $1.5 \mathrm{~cm}$ diam., smooth, pubescent; seeds not seen.

Notes. Tree to $15 \mathrm{~m}$ high and 30 $\mathrm{cm}$ diam., bark pale, slash exuding white latex; periodically white-water flooded (várzea) forest and forest transitional between várzea and terrafirme rain forest.

Distribution. NE Brazil (Amapá, Pará), Fr. Guiana.

\section{Pouteria torta (Martius) Radlkofer}

Leaves clustered, spirally arranged, pubescent or tomentose below, mixed with crisped hairs, or glabrous, with 14-25(-37) pairs of secondary veins. Fascicles usually clustered below the leaves, few-flowered, flowers bisexual, sepals 4, 0.3-1.5(-2) cm long, crisped pubescent to sericeous outside; pedicels $0-0.2 \mathrm{~cm}$ long, pubescent or tomentose. Fruit ellipsoid, ovoid or globose, $3-6.5 \mathrm{~cm}$ long, apex obtuse or rounded, base rounded to truncate, maturing yellow, smooth to verrucose, finely pubescent to densely covered in short hairy processes; seeds $1-4$, ellipsoid, $1.7-3.5 \mathrm{~cm}$ long, rounded at the ends, often plano-convex, sometimes slightly laterally compressed, testa smooth, shining, scar adaxial, often extending around the base, $0.2-1 \mathrm{~cm}$ wide.

Pouteria torta subsp. torta guapeva (B) Pl. 28, fig. 5

Leaves with 13-18 pairs of sec- 
ondary veins, crisped hairy below. Fruiting sepals $0.4 \times 0.5 \mathrm{~cm}$, brown pubescent outside; fruiting pedicels to $0.1 \mathrm{~cm}$ long. Fruit ellipsoid, $2 \times 1.5 \mathrm{~cm}$ to $3-3.5 \mathrm{~cm}$ long, yellow, smooth, densely brown pubescent, apiculate.

Notes. Shrub or gnarled tree to $15(-20) \mathrm{m}$ high and $75 \mathrm{~cm}$ diam., bark greyish-brown, deeply fissured, slash exuding white latex; dry cerrado and open campo, also in savanna (campina) and savanna forest (campinarana).

Distribution. $\mathrm{C}$ and Coastal Brazil, north into Pará and Rondônia.

Pouteria torta subsp. glabra Pennington

asipoko(balli) (A); abiuranacaranazal/gutta, coquirana-do-igapó (B) PI. 28, fig. 6

Leaves with 17-39 pairs of secondary veins, glabrous below. Fruiting sepals $0.8 \times 0.8 \mathrm{~cm}$, reddish-brown pubescent; fruiting pedicels $0-0.1 \mathrm{~cm}$ long. Fruit globose, $3 \times 3 \mathrm{~cm}$, sometimes to $5 \mathrm{~cm}$ long, at first green, maturing yellow-orange, finely rugulose, reddish-brown pubescent with caducous irritant hairs, apex with sunken, $0.2 \mathrm{~cm}$ long style remnant, pulp edible, sweet-tasting; seeds ellipsoid, 1.5 x $1.0 \times 0.9 \mathrm{~cm}$, sometimes to $3.5 \times 1.8$ $x 1.6 \mathrm{~cm}$, scar extending around base, 0.4-0.6 cm wide.

Notes. Tree to $32 \mathrm{~m}$ high and 50 $\mathrm{cm}$ diam., with up to $4 \mathrm{~m}$ high buttresses and fluted trunk, bark brown or greyish-white, scaling or shallowly fissured, slash pink to pale brown, exuding little white latex; at 20 and $80 \mathrm{~km}$ north of Manaus, golden-faced sakis (Pithecia pithecia chrysocephala) were seen predating on the immature seeds of this subspecies (Setz, 1993); periodically flooded forest and terrafirme rain and savanna forest, also found in lower montane forest, up to $1,000 \mathrm{~m}$ altitude.

Distribution. Bolivia, Am Brazil (Acre, Amapá, Amazonas, Pará, Rondônia, Roraima), Colombia, Fr. Guiana, Guyana, Peru, Venezuela.

Pouteria torta subsp. tuberculata

(Sleumer) Pennington

abiurana-de-goma (B) PI. 28, fig. 7

Leaves with 17-37 pairs of secondary veins; fruiting calyx accrescent, crisped pubescent outside, inner pair of sepals $1.5 \times 1.5 \mathrm{~cm}$, outer two $2 \times 1.5 \mathrm{~cm}$; fruits sessile. Fruit globose, $4.5-6.5 \mathrm{~cm}$ diam., green, maturing orange-yellow, verrucose, densely covered with coriaceous, tomentose, to 0.5 $\mathrm{cm}$ long bristles; seeds to $4,2 \times 1.3 \times$ 1.1 to $2.5 \times 1.4 \times 1.2 \mathrm{~cm}$, scar $0.4 \mathrm{~cm}$ wide.

Notes. Tree to $35 \mathrm{~m}$ high and 60 $\mathrm{cm}$ diam., with slender buttresses and fluted bole, bark dark brown, scaling with thin longitudinal pieces, sometimes shallowly fissured, slash cream, exuding white latex; in the R. Urucú region, Amazonas, Brazil, Peres (1994) saw Geoffroy's woolly monkeys (Lagothrix lagotricha cana) feeding on the ripe pulp, swallowing the seeds, and at $20 \mathrm{~km}$ north of Manaus, Amazonas, Brazil, golden-faced sakis (Pithecia pithecia chrysocephala) (Setz, 1993) were seen predating upon the immature seeds of this subspecies, whereas red-faced black spider monkeys (Ateles paniscus) fed on the mature pulp, dispersing the seeds 

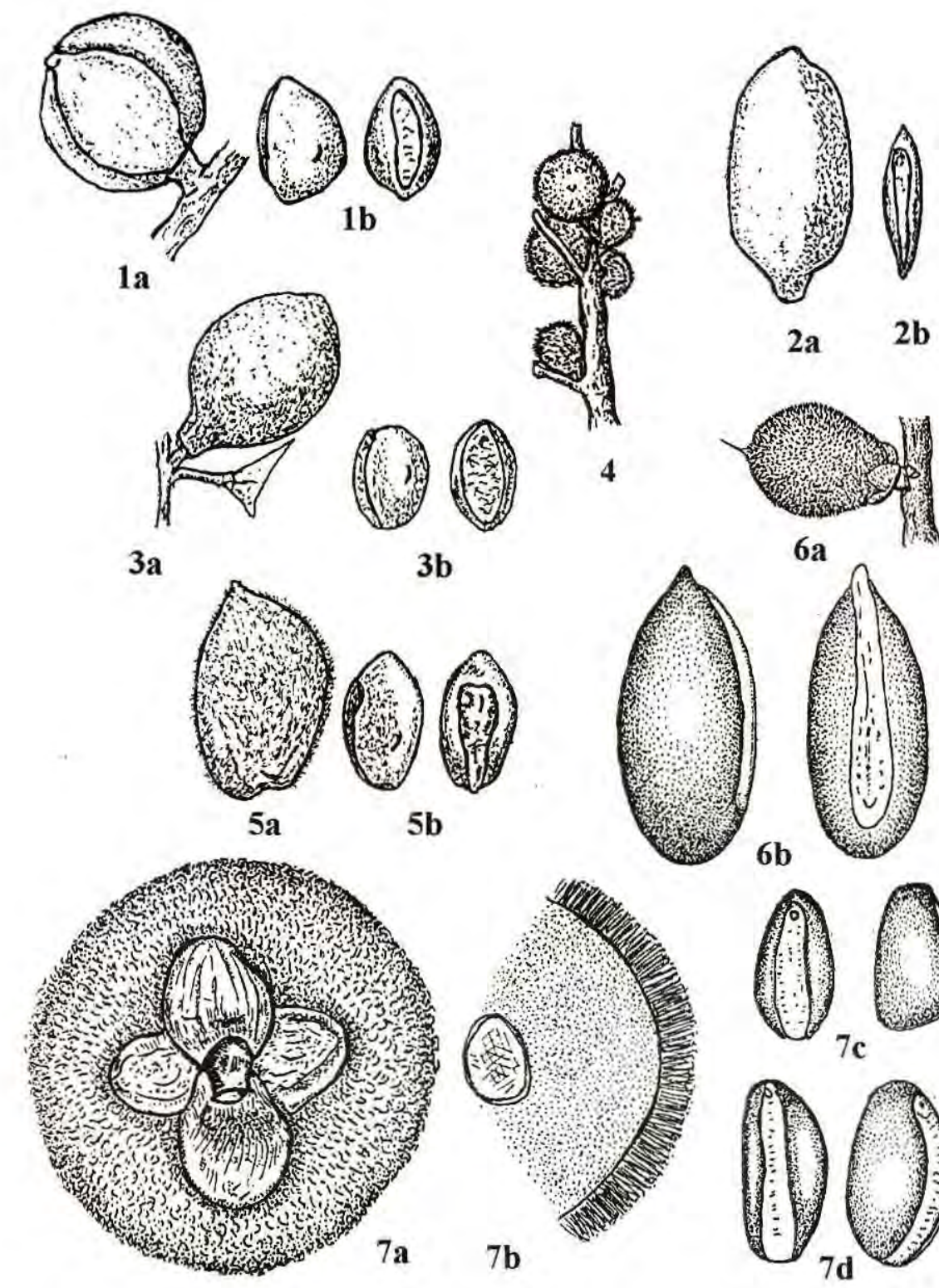

$6 b$
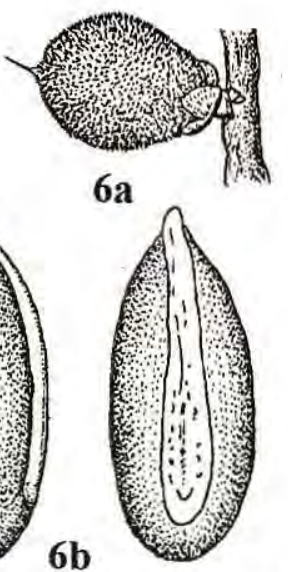

PI. 28. Figs. 1-7. SAPOTACEAE. I. Pouteria plicata, a. fruit; b. seed, lateral and frontal view (Revilla 2250; Rodrigues \& Lima 2270). 2. P. singularis, a. fruit; b. seed, frontal view (Pires et al. 50723). 3. P. stipitata, a. fruit; b. seed, lateral and frontal view (Croat 6116; Aristeguieta 12592). 4. P. tenuisepala, young infructescence (Oldeman 932). 5. P. torta subsp. torta, a. fruit; b. seed, lateral and frontal view (Eiten \& Campos 3450). 6. P. torta subsp. glabra, a. young fruit; b. ripe seed; lateral and frontal view (Van Roosmalen 16, 163, 164). 7. P. torta subsp. tuberculata, a. fruit from below; b. cross section of part of fruit; $c, d$, seed, frontal and lateral view (Van Roosmalen 17, 18, 19, 108). 
endochorically; lowland terra-firme rain forest.

Distribution. Brazil (Acre, Amazonas), Colombia, Fr. Guiana, Peru.

\section{Pouteria Section 7. Aneulucuma}

(Radlkofer) Pennington

Leaves with often oblique tertiary venation. Calyx of (4-)6(-11), usually spirally arranged sepals. Seeds usually broadly ellipsoid, testa smooth, verruculose, striate or finely pitted, scar adaxial, broad, covering half to $3 / 4$ of the seed surface.

\section{Pouteria ephedrantha (A.C. Smith)} Pennington PI. 29, fig. 1

Leaves spaced, spirally arranged, coriaceous, with a very close pale greyish or white appressed indumentum on the lower surface, with 12-20 pairs of secondary veins. Fascicles axillary and below the leaves, 3-10-flowered, flowers bisexual, sepals 6 , outer ones $0.15 \mathrm{~cm}$ long, inner ones $0.35 \mathrm{~cm}$ long, appressed puberulous; fruits sessile. Fruit obovoid, $3.2-4 \mathrm{~cm}$ long, apex rounded, base obtuse, smooth, at first pubescent, maturing brown and glabrous, epicarp thin; seeds $1-2$, broadly ellipsoid or plano-convex, $2.7-3.3 \mathrm{~cm}$ long, rounded or obtuse at the ends, testa rough, finely pitted, adherent to the pericarp, scar $1.3-1.7 \mathrm{~cm}$ wide, strongly pitted and verrucose.

Notes. Tree to $40 \mathrm{~m}$ high and 65 $\mathrm{cm}$ diam., slash exuding white latex; periodically white-water flooded (várzea) forest and alluvial flood plains, at $100-700 \mathrm{~m}$ altitude.

Distribution. Am Brazil (Acre, S Amazonas), Am Peru.
Pouteria procera (Martius) Pennington abiurana-cascuda, caramuri-devárzea, maçaranduba-de-várzea (B) Pl. 29, fig. 2

Leaves spaced, spirally arranged, thinly coriaceous, glabrous, with 9-15 pairs of secondary veins. Fascicles axillary and below the leaves, 3-12flowered, flowers bisexual, sepals 56 , arranged in a short spiral, outer ones 0.15-0.2 cm long, inner ones 0.3-0.35 $\mathrm{cm}$ long, appressed puberulous to glabrous outside, sericeous inside; pedicels to $0.2 \mathrm{~cm}$ long, sometimes bearing 1-2 small bracts. Fruit broadly obovoid, $3.5-4 \mathrm{~cm}$ long, apex rounded, base attenuate, yellow or orange when ripe, smooth, epicarp thin (shrinking on drying), covered with appressed puberulous indumentum; seeds $1-2$, broadly ellipsoid, $2-3 \mathrm{~cm}$ long, rounded at the ends, testa smooth to slightly verruculose, scar usually extending around the base, $0.6-1.2 \mathrm{~cm}$ wide, rough

Notes. Tree to $45 \mathrm{~m}$ high and 1 $\mathrm{m}$ diam., with up to $2 \mathrm{~m}$ high buttresses, slash exuding white latex; Guianan brown capuchin monkeys (Cebus apella apella) fed on the ripe pulp, $80 \mathrm{~km}$ north of Manaus, Amazonas, Brazil (Spironelo, pers. comm.); wet lowland rain forest, often on periodically flooded land, up to $700 \mathrm{~m}$ altitude.

Distribution. Am Bolivia, Am Brazil (Acre, Amapá, Amazonas, Pará, Rondônia), Am Peru.

Pouteria Section 8. Gayella (Pierre) Pennington

Leaves with oblique or reticulate, often obscure higher venation. Calyx of 4-5(-6) sepals. Seeds ellip- 
soid, testa smooth or slightly wrinkled, scar adaxial, broad or narrow.

Pouteria decussata (Ducke) Baehni preguiçera (B)

Leaves loosely clustered, opposite (decussate), coriaceous, with 1213 pairs of secondary veins. Fascicles axillary and below the leaves, 3-5flowered, sepals 4-5, lanceolate, 0.3 cm long, appressed pubescent; pedicels $0.4-0.7 \mathrm{~cm}$ long, appressed pubescent. Fruit not known.

Notes. Tree to $15 \mathrm{~m}$ high and 25 cm diam.; hill forest.

Distribution. Brazil (Pará).

Pouteria eugeniifolia (Pierre) Baehni

abiú-farinha-seca, abiú-ucuuba, batinga (B) Pl. 29, fig. 3

Leaves spaced, opposite and spirally arranged, thinly coriaceous, glaucous below, glabrous, with $15-22$ pairs of secondary veins. Fascicles axillary and below the leaves, 3-25-flowered, flowers bisexual, sepals (4-)5(-6), 0.1$0.15 \mathrm{~cm}$ long, appressed puberulous, in fruit to $0.2 \mathrm{~cm}$ long; pedicels $0.3-1$ $\mathrm{cm}$, in fruit up to $1.5 \mathrm{~cm}$ long, sparsely appressed puberulous. Fruit subglobose, 1.5-2 x 1.3-1.5 cm long, apex rounded, base rounded or slightly tapered, russet when mature, smooth, appressed puberulous with ferruginous hairs; seeds 1 , broadly ellipsoid or subglobose, $1-1.3 \mathrm{~cm}$ long, testa smooth, scar adaxial, $0.3-0.5 \mathrm{~cm}$ wide.

Notes. Tree to $40 \mathrm{~m}$ high and 60 $\mathrm{cm}$ diam., with steep buttresses merging into a fluted bole, bark scaling in large irregular pieces, slash pinkish brown, exuding creamy-white latex; black bearded sakis (Chiropotes satanas chiropotes) were seen predat- ing on the immature seeds, $80 \mathrm{~km}$ north of Manaus, Amazonas, Brazil (Frazão, 1992); terra-firme rain forest up to $1,100 \mathrm{~m}$ altitude.

Distribution. Am Brazil (Amazonas, Pará), Guianas, Venezuela.

\section{Pradosia Liais}

Leaves often opposite or verticillate, sometimes spirally arranged, with often impressed venation on upper surface; minute paired stipels sometimes present on petiole. Inflorescences usually cauliflorous or ramiflorous, less frequently axillary; flowers bisexual, corolla often dark red, calyx with a single whorl of usually 5 sepals. Fruit a drupe, often slightly asymmetric, endocarp thinly cartilaginous; seeds 1 , with smooth, shining testa and adaxial scar, extending the full length of the seed.

Notes. Trees, with 23 species in South America and one species extending into Central America, mostly confined to lowland rain forest.

\section{Pradosia atroviolacea Ducke PI. 29, fig. 4}

Leaves clustered, spirally arranged or verticillate, chartaceous or thinly coriaceous, glabrous, with 15 16 pairs of secondary veins, stipels present, ca. $0.1 \mathrm{~cm}$ long, fixed $0.5-1$ $\mathrm{cm}$ above base of petiole. Fascicles on twigs and larger branches, many-flowered, flowers dark violet, sepals (4-)5, $0.25-0.3 \mathrm{~cm}$ long, finely appressed puberulous; pedicels $0.2-0.3 \mathrm{~cm}$ long, finely appressed puberulous. Fruit broadly oblong-ellipsoid, asymmetric, 4-5 cm long, acute at the ends, smooth, finely appressed puberulous.

Notes. Tree to $40 \mathrm{~m}$ high and 1 
m diam., bole cylindrical, slash exuding white latex, bark bitter and astringent tasting; periodically flooded forest and terra-firme lowland rain forest, to $100 \mathrm{~m}$ altitude.

Distribution. W Am Brazil (Acre, W Amazonas), Am Colombia.

Pradosia cochlearia (Lecomte) Pennington

Leaves clustered, verticillate or spirally arranged, chartaceous, with 10-12 pairs of secondary veins, stipels absent. Fascicles clustered below the leaves, 5-10-flowered, sepals 5, ca. 0.2 $\mathrm{cm}$ long, appressed puberulous; pedicels $0.05-0.3 \mathrm{~cm}$ long, appressed puberulous. Fruit ellipsoid, to $3.8-5$ $\mathrm{cm}$ long, when dried with long tapered acute apex, smooth, subglabrous; seed oblong, to $2.2-2.8 \mathrm{~cm}$ long, not laterally compressed, apex rounded or acute, base acute, scar 0.6-0.7 cm wide.

Pradosia cochlearia (Lecomte)

Pennington subsp. cochlearia

casca-doce, pau-doce (B)

Leaves finely rufous sericeous below, tertiary venation obscure. Flowers greenish with somewhat reddish pubescence.

Notes. Tree to $40 \mathrm{~m}$ high, trunk slightly fluted, buttresses large; lowland terra-firme rain forest.

Distribution. Brazil (Pará), French Guiana.

Pradosia cochlearia (Lecomte) Pennington subsp. praealta (Ducke) Pennington

casca-doce, miraceem, pau-doce (B) Pl. 29, fig. 5

Leaves glabrous, tertiary venation visible. Flowers greenish, gla- brous. Fruit ellipsoid, $2.1 \times 1.6$ to 2.7 $\mathrm{x} 1.7 \mathrm{~cm}$, green, maturing pale yellow, weighing $150 \mathrm{~g}(\mathrm{n}=40)$; seed 1.6-1.9 x $1.1-1.2 \times 0.9 \mathrm{~cm}$, weighing $14 \mathrm{~g}$ $(n=40)$.

Notes. Tree to $50 \mathrm{~m}$ high, buttresses to several metres high, bark smooth, greyish-white, sweet-tasting; in the R. Urucú region, Peres (1993) saw two species of tamarin (Saguinus mystax pileatus and $S$. fuscicollis avilapiresi) feeding on the mature pulp, whereas parrots and parakeets (Pionites and Pyrrhura) predated upon the immature seeds; lowland terrafirme forest on sandy soil.

Distribution. Am Brazil (Amazonas, Pará, Rondônia).

\section{Pradosia decipiens Ducke}

Leaves clustered, spirally arranged, coriaceous, minutely brown puberulous below, with 11-13 pairs of secondary veins, stipels absent. Fascicles densely clustered below the leaves, 10-15-flowered, flowers white, sepals ca. $0.3 \mathrm{~cm}$ long, glabrous; pedicels $0.5-0.7 \mathrm{~cm}$ long, glabrous. Fruit obliquely oblong-ovoid, ca. 3,4 $\mathrm{x} 1.5 \mathrm{~cm}$, apex obtuse, base attenuate, one side straight, other side curved.

Notes. Tree to $30 \mathrm{~m}$ high, trunk with buttresses, bark smooth, pale yellowish, astringent-tasting; lowland terra-firme rain forest.

Distribution. Brazil (C Amazonas, only once collected along R. Tarumã).

Pradosia granulosa Pires \& Pennington PI. 29, fig. 6

Leaves spaced, subverticillate, 
coriaceous, finely short puberulous below, with 16-20 pairs of secondary veins, stipels absent. Fascicles axillary and below the leaves, 10-15-flowered, flowers reddish-green, sepals ca. 0.2 $\mathrm{cm}$ long, appressed puberulous; pedicels $0.2-0.3 \mathrm{~cm}$ long, appressed puberulous. Fruit broadly oblong-elliptic, 3-3.5 cm long, sometimes asymmetric, apex obtuse or apiculate, base obtuse, maturing yellow, shallowly and irregularly ribbed and verruculose, granular-papillose; seed oblong-ellipsoid, $2-2.5 \mathrm{~cm}$ long, slightly asymmetric, not laterally compressed, scar $0.2-0.3 \mathrm{~cm}$ wide.

Notes. Tree to $10 \mathrm{~m}$ high, slash exuding white latex; lowland terrafirme rain forest up to $250 \mathrm{~m}$ altitude.

Distribution. Brazil (Maranhão, S Pará).

\section{Pradosia huberi (Ducke) Ducke}

pau-doce, pracuuba (B)

Leaves spaced or loosely clustered, opposite, chartaceous, glabrous, with $10-15$ pais of secondary veins, stipels absent. Fascicles clustered below the leaves, 2-5-flowered, flowers whitish, sepals ca. $0.2 \mathrm{~cm}$ long, appressed puberulous; pedicels 0.1-0.4 $\mathrm{cm}$ long, appressed puberulous. Fruit ovoid or elliptic, $3-3.5 \mathrm{~cm}$ long, apex and base rounded, glabrous.

Notes. Tree to $30 \mathrm{~m}$ high with large buttresses, bark greyish-white and sweet-tasting; swamp and permanently flooded forest.

Distribution. Brazil (Pará), French Guiana.

\section{Pradosia ptychandra (Eyma)}

Pennington kimboto (S); kimboto, kwatabobi, wetimalobi (P) PI. 29, fig. 7

Leaves clustered, spirally, arranged, chartaceous, glabrous, with $10-$ 13 pairs of secondary veins, stipels absent. Fascicles many-flowered, borne on finger-thick twigs and trunk, flowers wine red, sepals ca. $0.2 \mathrm{~cm}$ long, finely appressed puberulous; pedicels 0.9-1.2 $\mathrm{cm}$, in fruit to $2 \mathrm{~cm}$ long and stout; fruits solitary or in clusters. Fruit globose or broadly ellipsoid, $3.3-4 \times 2.8-5 \mathrm{~cm}$, rounded at the ends, apex sometimes abruptly acuminate, at first green, maturing bright orange-yellow, smooth, glabrous, the outer pericarp $(0.4 \mathrm{~cm})$ is yellow and rather hard, the inner $0.3 \mathrm{~cm}$ is soft, transparent, and sweet-tasting; seed oblong-ellipsoid, ca. $2.5 \mathrm{~cm}$ long, slightly laterally compressed, testa cartilaginous, smooth or horizontally striate, scar $0.8-0.9 \mathrm{~cm}$ wide, rough.

Notes. Tree to $25 \mathrm{~m}$ high and 55 $\mathrm{cm}$ diam., trunk cylindrical, bark greyish-brown, smooth or with dense depressions, often with vertical rows of lenticels, slash cream with orange streaks, exuding sticky white latex; fruits consumed and seeds dispersed by Guianan red howling monkeys (Alouatta seniculus macconnelli); terra-firme rain forest over clay and sand, at $200-600 \mathrm{~m}$ altitude.

Distribution. Fr. Guiana, Suriname.

Pradosia schomburgkiana (A. de Candolle) Cronquist

Leaves spaced, opposite, thinly coriaceous, with 14-22 pairs of secondary veins, stipels absent. Fascicles clustered below the leaves, 5-25-flow- 

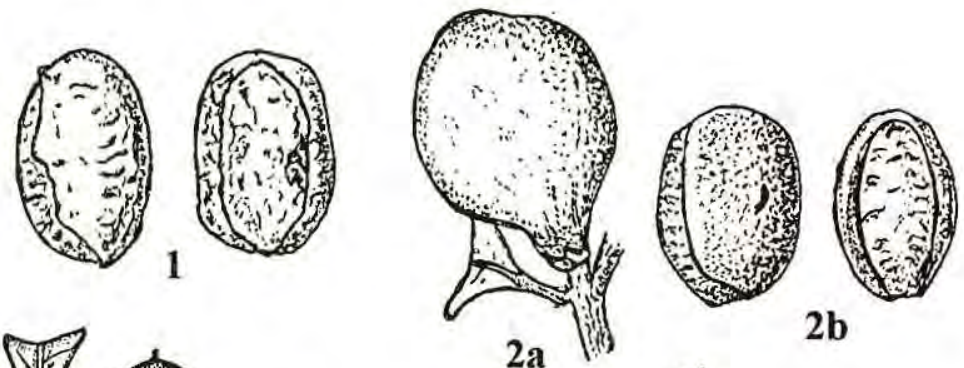

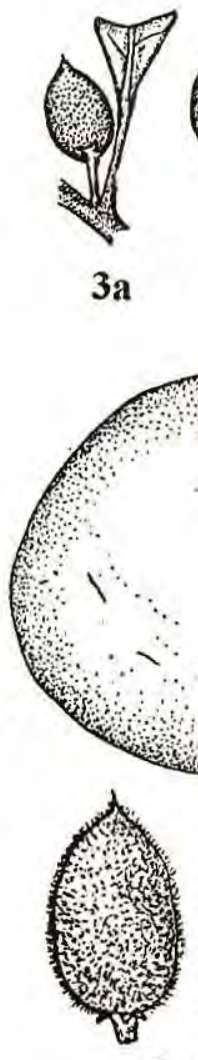

$6 \mathbf{a}$

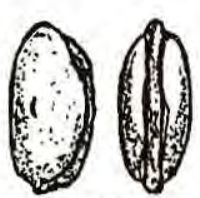

6b
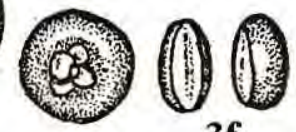

3f

3d
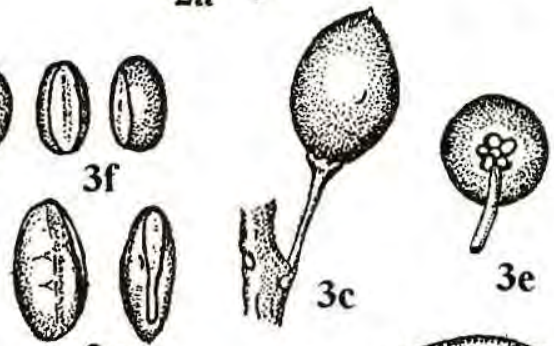

$3 \mathbf{e}$

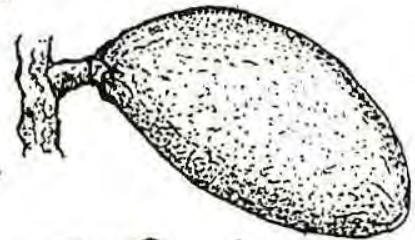

4

PI. 29. Figs. 1-7. SAPOTACEAE. 1. Pouteria ephedrantha, seed, lateral and frontal view (Forster \& Janson 8487). 2. P. procera, a. fruit; b. seed, lateral and frontal view (Van Roosmalen 182; Steyermark et al. 101941; Curran 25). 3. P. eugeniifolia, a. young fruit; b, c. fruit; d, e. fruit from below; $f$, g. seed, lateral and frontal view (Van Roosmalen 150, 173). 4. Pradosia atroviolacea, fruit (Rimachi 4335). 5. P. cochlearia subsp, praealta, fruit (Ducke 1663). 6. Pradosia granulosa, a. fruit; b. seed, lateral and frontal view (Maciel et al. 533). 7. P. ptychandra, a. infructescence; b. seed, lateral and frontal view (Van Roosmalen S57; Pennington \& Mori 12103). 
ered, sepals (4-)5(-6), 0.1-0.25 cm long, appressed puberulous or glabrous; pedicels $0.1-0.9 \mathrm{~cm}$ long, appressed puberulous to glabrous. Fruit broadly ellipsoid or obovoid, $1.2-2 \mathrm{~cm}$ long, apex rounded, sometimes apiculate, base rounded or tapered, smooth, minutely appressed puberulous; seed subglobose to ellipsoid, usually slightly compressed, $0.85-1.5 \mathrm{~cm}$ long, scar about $2 / 3$ the seed length, $0.2-0.5 \mathrm{~cm}$ wide.

Pradosia schomburgkiana (A. de

Candolle) Cronquist subsp.

\section{schomburgkiana}

cacarrowa, kakarua (A); ajarahy, casca-doce, pau-doce, miraceem (B) Pl. 30, fig. 1

Leaves glabrous. Flowers greenish-white. Fruit maturing yellow or orange, subglabrous, pulp edible, sweettasting.

Notes. Shrub or tree to ca. $10 \mathrm{~m}$ high in (scrub) savanna, campina and savanna woodland over shallow, often white sands, also tree up to $36 \mathrm{~m}$ and $50 \mathrm{~cm}$ diam., with buttresses, in savanna forest and wallaba (Eperua) forest in montane region (of Guyana), up to $1,400 \mathrm{~m}$; bark light brown to reddish, scaling, with sweet-tasting inner bark, slash exuding white latex.

Distribution. N + C Am Brazil (Amazonas, Pará, Roraima), Am Colombia, Guyana, Suriname, S Venezuela.

Pradosia schomburgkiana (A. de Candolle) Cronquist subsp. sericea

Pennington PI. 30, fig. 2

Leaves finely golden-brown or grey sericeous below. Flowers greenishyellow. Fruit appressed puberulous, ferruginous-brown.

Notes. Shrub or small tree to 10 $\mathrm{m}$ high, crown broad and dense, slash exuding white latex; open savanna and scrub savanna, at 100-1,400 m altitude.

Distribution. Brazil (NAmazonas - Serra Aracá), S Venezuela.

\section{Pradosia subverticillata Ducke}

casca-doce, pau-doce (B) Pl. 30, fig. 3

Leaves clustered, subverticillate, thinly coriaceous, glabrous, with 15 18 pairs of secondary veins, stipels absent. Fascicles densely clustered in leaf axils and below the leaves, many-flowered, flowers greenish, sepals 5, 0.25-0.3 $\mathrm{cm}$ long, appressed pubescent; pedicels $0.4-0.6 \mathrm{~cm}$, in fruit to $0.8 \mathrm{~cm}$ long. Fruit subfalcate-oblong, $2.5-4 \times 1-1.5 \mathrm{~cm}$, apex acuminate over to $0.4 \mathrm{~cm}$ or apiculate, one side straight, the other strongly arcuate-convex, base tapered over to $0.4 \mathrm{~cm}$, smooth, subglabrous; seed subfalcate-oblong, $2.4 \times 1.1 \times 1$ $\mathrm{cm}$, testa shining, with an oblong, 0.3 $0.4 \mathrm{~cm}$ wide, dull-brown scar extending around the base.

Notes. Tree to $20 \mathrm{~m}$ high, bole cylindrical, bark yellowish-grey, smooth, sweet-tasting; terra-firme rain and savanna forest over sandy soils.

Distribution. Am Brazil (C Amazonas, Pará).

Pradosia surinamensis (Eyma)

Pennington

kimboto (S); boesisoké, monkisomi (P) Pl. 30, fig. 4

Leaves spaced or loosely clustered, spirally arranged, coriaceous, glabrous, with 9-14 pairs of secondary veins, stipels absent. Fascicles below the leaves, few-flowered, flowers greenish-yellow, sepals 5 , ca. $0.15 \mathrm{~cm}$ long, minutely appressed puberulous, in fruit to $0.6 \mathrm{~cm}$ long; pedicels 0.1 - 
$0.2 \mathrm{~cm}$ long, appressed puberulous, in fruit 0.3-0.4(-0.9) cm long. Fruit ellipsoid to globose, $2.5 \times 1.4 \mathrm{~cm}$ to $4 \mathrm{~cm}$ diam., apex obtuse, base sometimes slightly tapered, green to light yellow, maturing orange-red, smooth, finely appressed puberulous, glabrescent, pulp light yellow, sweet-tasting; seed oblong-elliptic, $1.2 \times 1 \times 0.9 \mathrm{~cm}$ to 2.5 $x 1.4 \mathrm{~cm}$, slightly laterally compressed, base slightly tapered, testa dark brown, smooth, shining, scar adaxial, $0.4-0.9 \mathrm{~cm}$ wide, full-length.

Notes. Tree to $32 \mathrm{~m}$ high and 80 $\mathrm{cm}$ diam., with up to $1 \mathrm{~m}$ high buttresses and fluted bole, bark dark brown, slash exuding white latex; lowland terra-firme rain and savanna (campinarana) forest, especially along creek and river margins.

Distribution. Brazil (Pará, Roraima), Guyana, Suriname, Venezuela (Bolivar).

\section{Pradosia verticillata Ducke Pl. 30, fig. 5}

Leaves loosely to densely clustered, verticillate, in whorls of 5-7, coriaceous, dark brown-pubescent below, with 23-26 pairs of secondary veins, stipels absent. Fascicles on branches and twigs, 5-10-flowered, flowers dark violet, sepals 5 , ca. $0.2 \mathrm{~cm}$ long, appressed puberulous; pedicels ca. 0.1 $\mathrm{cm}$ long, appressed puberulous, in fruit $0.25 \mathrm{~cm}$ long. Fruit narrowly obovoid, $3.5-5 \times 3 \mathrm{~cm}$, asymmetric, one side straight or concave, the other convex, apex rounded, base tapered, smooth, glabrous; seed 2.5-3.1 x 1.3-0.8 x 0.5 $\mathrm{cm}$, laterally compressed, apex rounded, base acute, asymmetric, testa smooth, shining, scar adaxial, ca. 0.4 $\mathrm{cm}$ wide, full-length.

Notes. Tree to $33 \mathrm{~m}$ high and 35 $\mathrm{cm}$ diam., with simple, stout and to 50 $\mathrm{cm}$ high buttresses, bark pale buffbrown, peeling in large irregular thin pieces, becoming dippled, slash orange-brown, exuding sticky white latex, crown broad, with massive twigs and dense terminal leaf clusters; lowland terra-firme rain and savanna forest, up to $400 \mathrm{~m}$ altitude.

Distribution. Brazil

(C Amazonas), French Guiana.

\section{Sarcaulus Radlkofer}

Leaves spaced, alternate and distichous or less frequently weakly spirally arranged. Flowers unisexual, calyx a single whorl of usually 5 sepals. Fruit a berry; seeds 1-several, laterally compressed, testa smooth or wrinkled, shining, scar adaxial, full-length, narrow.

Notes. Trees; 5 species in tropical South America.

Sarcaulus brasiliensis (A. de Candolle) Eyma subsp. brasiliensis fig. 6 guajara (do igapó) (B) Pl. 30,

Leaves spaced, spirally arranged or alternate and distichous, chartaceous or thinly coriaceous, glabrous, with 8-12 pairs of secondary veins. Fascicles axilary and below the leaves, 1-8-flowered, sepals 0.15-0.25 $\mathrm{cm}$ long, appressed puberulous; pedicels $1-1.5 \mathrm{~cm}$ long, often recurved or coiled, appressed puberulous. Fruit subglobose to ellipsoid, $2.2 \times 1.8 \mathrm{~cm}$ to $3.2 \mathrm{~cm}$ long, apex acute to rounded, base rounded to tapered, yellow, smooth, glabrous or sparsely appressed puberulous, pulp sticky white; 
seeds 1-2, depressed ellipsoid, 1.2-1.7 $\times 1.1 \times 0.6 \mathrm{~cm}$, rounded at the ends, testa brown, shining, smooth, scar $0.2-$ $0.4 \mathrm{~cm}$ wide, usually extending around the base, dull brown.

Notes. Tree to $30 \mathrm{~m}$ high and 35 $\mathrm{cm}$ diam,, bark smooth or slightly scaling, pale greyish, bole cylindrical, slash pinkish-red, exuding copious white latex, crown small with horizontally spreading branches; lowland terra-firme and lower montane rain forest, also on periodically flooded land (várzea).

Distribution. Am Bolivia, Am Brazil (Amapá, Amazonas, Pará), Guianas, Am Peru.

\section{Sarcaulus inflexus (A.C. Smith)}

Pennington

cramary (B) Pl. 30, fig. 7

Leaves spaced, alternate and distichous, thinly coriaceous, glabrous, with 7-9 pairs of secondary veins. Fascicles mostly below the leaves, 3-8flowered, sepals ca. $0.4 \mathrm{~cm}$ long, sericeous; pedicels 1.8-2(-3) cm long, appressed puberulous. Fruit not known in mature stage.

Notes. Tree to $12 \mathrm{~m}$ high, slash exuding white latex; terra-firme rain forest.

Distribution. Am Brazil (C Amazonas, Mato Grosso).

\section{Sarcaulus vestitus (Baehni) Pennington}

Leaves spaced, alternate and distichous, chartaceous, appressed whitish-puberulous below, with 9-13 pairs of secondary veins. Fascicles axillary and below the leaves, 2-5-flowered, sepals ca. $0.2 \mathrm{~cm}$ long, appressed puberulous; pedicels $0.3-0.4 \mathrm{~cm}$ long, appressed puberulous. Fruit ellipsoid, ca. $2 \mathrm{~cm}$ long, apex acute, base obtuse, yellow, smooth, glabrous; seeds 1 , ca. $1.6 \mathrm{~cm}$ long, laterally compressed, rounded at the ends, testa finely transversely wrinkled, shining, scar ca. 0.4 $\mathrm{cm}$ wide.

Notes. Tree to $12 \mathrm{~m}$ high, slash exuding white latex; periodically white-water flooded forest (várzea).

Distribution. Am Brazil (Acre, W Amazonas).

\section{ACKNOWLEDGEMENTS}

We would like to thank Mrs. Lambertha Blijenberg for illustrating the fruits and seeds. The following students and researchers kindly shared data on fruit and seed consumption by animals: Dr. Carlos A. Peres, Dra. Eleonore Z.F. Setz, Dr. Jean-Philippe Boubli, Dr. Thomas R. Defler, Silvia Egler, Edson da Rocha Frazão, and Wilson Spironelo.

\section{Literature cited}

Aguiar, J.P.L.; Marinho, H.A.; Rebelo, Y.S.; Shrimpton, R. 1980. Aspectos nutritivos de alguns frutos da Amazônia. Acta Amazonica, 10:755-758.

Aguirre, A.C. 1971. O mono Brachyteles arachnoides (E. Geoffroy). A situação atual da espécie no Brasil. Academia Brasileira de Ciencias, Rio de Janeiro, Brazil.

Alencar, J.; Almeida, R.A.; Fernandes, N.P. 1979. Fenologia de espécies florestais em floresta tropical úmida de terra firme na Amazónia Central. Acta Amazonica, 9(1): 163-198 

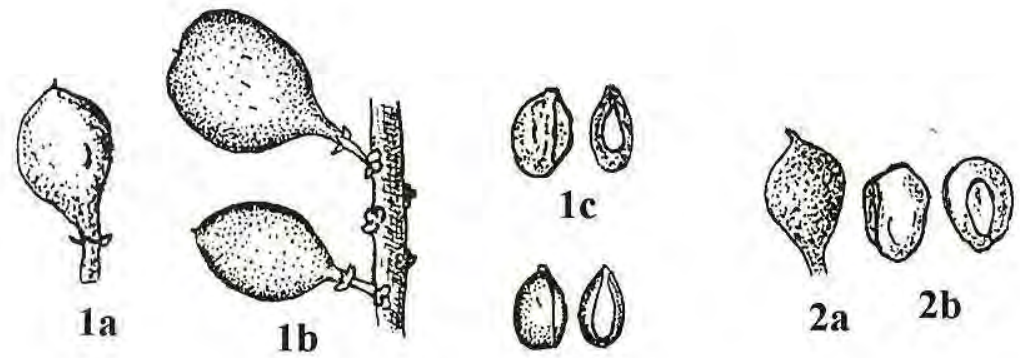

$2 \mathrm{a}$

2b

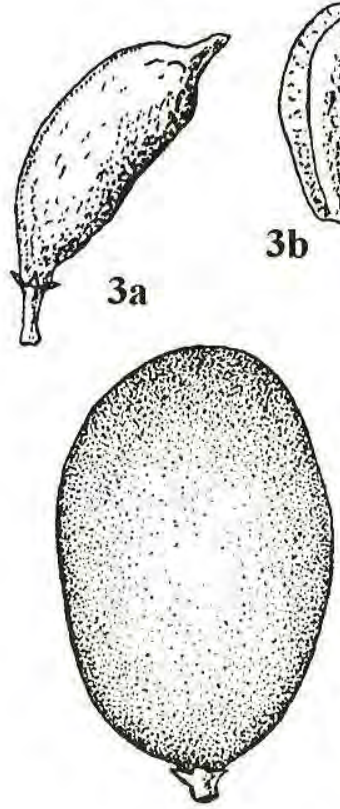

5a

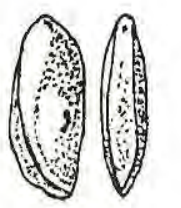

$5 b$
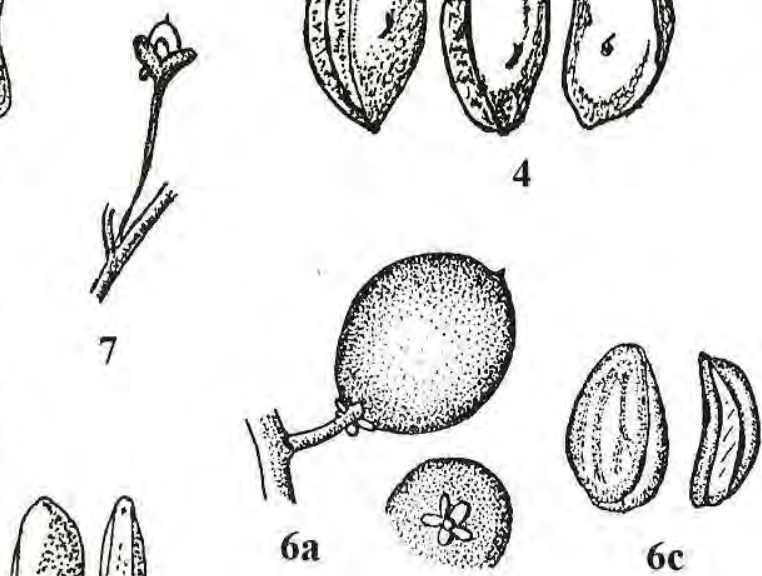

6b

PI. 30. Figs. 1-7. SAPOTACEAE. 1. Pradosia schomburgkiana subsp. schomburgkiana, a. fruit; b. infructescence; $\mathrm{c}$, d. seed, lateral and frontal view (Van Roosmalen 105). 2. P. schomburgkiana subsp. sericea, a fruit; b, seed, lateral and frontal view (Huber 1772). 3. P. subverticillata, a fruit; b. seed (Van Roosmalen 119, 120). 4. P. surinamensis, seed. 5. P. verticillata, a. fruit; b. seed, lateral and frontal view (Ducke 881). 6. Sarcaulus brasiliensis subsp. brasiliensis, a. fruit; b. fruit from below; c. seed, lateral and frontal view (Van Roosmalen 106). 7. S. inflexus, young fruit (Rodrigues et al. 2852). 
Ayres, J.M. 1981. Observações sobre a ecologia e o comportamento dos cuxiús (Chiropotes albinasus e Chiropotes satanas, Cebidae: Primatas). Fadesp/ Gráfica, Belém, Brazil, 142 pp.

Ayres, J.M. 1986. Uakaris and Amazonian flooded forest. Cambridge University, Cambridge, U.K.

Ayres, J.M. 1989. Comparative feeding ecology of the uakari and bearded saki, Cacajao and Chiropotes. Journal of Human Evolution, 18: 697-716.

Ayres, J.M. 1993. As matas de várzea do Mamirauá. Rio de Janeiro, MCT-CNPq.

Boubli, J.P. 1997. Ecology of the black uakari monkey, Cacajao melanocephalus melanocephalus, in Pico da Neblina National Park, Brazil. Unpublished Ph. D. Dissertation, Department of Anthropolgy, University of California, Berkeley, U.S.A.:218pp.

Buchanan, D.; Mittermeier, R.A.; Van Roosmalen, M.G.M. 1981. The saki monkeys, genus Pithecia, In: Ecology and Behavior of Neotropical Primates. Vol. I. Coimbra-Filho A. \& Mittermeier, R.A. eds. Academia Brasileira de Ciências, Rio de Janeiro, Brazil:391-417.

Cavalcante, P.B. 1976. Frutas comestiveis da Amazónia. Ed. Frahia Neto, $2^{\circ}$ Ed. Belém, Brazil, Falangola, 146 pp.

Cavalcante, P.B. 1988. Frutas comestiveis da Amazônia. $4^{\text {th }}$ ed. rev.- Belém: Museu Paraense Emílio Goeldi, 279 pp.

Charles-Dominique,P.; Atramentowicz, M.; CharlesS-Dominique, M.; Gerard, H.; Hladik, A; Hladik, C.M.; Prevost, M.F. 1981. Les mammifères frugivores arboricoles nocturnes d'une forêt Guyanaise: Interrelaions plantes-animaux. Revue d'Écologie (Terre et Vie), 35:341435.

Ducke, A. 1949. Árvores Amazônicas e sua popagaçâo. Adaptação de frutos ou sementes de árvores Amazônicas a diversos meios de propagação em espécies de estreita afinidade botânica, porém $\mathrm{em}$ condições mesológicas diferentes. Boletim do Museu Paraense Emílio Goeldi.
Vol.X. Belém-Pará, Brazil: 81-92.

Foster, M.S. 1977. Ecological and nutritional effects of food scarcity on a tropical frugivorous bird and its fruit source. Ecolgy, 58:73-85.

Frazão, E.R. 1992. Dieta e estratégia de forragear de Chiropotes satanas chiropotes (Cebidae: Primatas) na Amazònia Central Brasileira. Unpublished Masters dissertation INPA/FUA, ManausAM, Brazil: 98pp.

Freese, C.M.; Oppenheimer, J.R. 1981. The capuchin monkeys, genus Cebus. In: Coimbra-Filho, A.; Mittermeier, R.A. (eds) Ecology and Behavior of Neotropical Primates Vol I. , Academia Brasileira de Ciências, Rio de Janeiro, Brail: 331390.

Gautier-Hion, A.; Duplantier, J.M.; QurisS, R.; Freese, F.; Sourd, C.; Decoux, J.P.; Dubost, G.; Emmons, L.; Erard, C.; Heckets, W.P.; Mounganzi, A.; Rounilion, C.; Thiolla, J.M. 1985. Fruits as a basis of fruit choice and seed dispersal in a tropical forest vertebrate community. In: Oecologia (Berlin), 65:324-337.

Goulding, M. 1980. The fishes and the forest. Berkeley, University of California Press. Berkeley. 200 p.

Grandlemire, S.J. 1988. An ecological comparison of two sympatric primates Saguinus fuscicollis and Callicebus moloch of Amazonian Peru. Primates, 29 (4): $\quad 465-475$.

Howe, H.F. 1977. Bird activity and seed disersal of a tropical wet forest tree. Ecology, 58:539-550.

Howe, H.F. 1979. Fear and frugivory. The American Society of Naturalist, 114 (6):925-931.

Howe, H.F. 1980. Monkey dispersal and waste of a neotropical fruit. Ecology, 61 (4): 944-959.

Howe, H.F. 1983. Annual variation in a tropial seed-dispersal system. In: Tropial rain forest: ecology and management. Eds. Sutton, S.L.; Whitmore, T.C. \& Chadewich, A.C. Blacke Well Scientific Publications, Oxford London Edinburg 
Boston Melbourne:211-227.

Howe, H.F.; Estabrook, G.F. 1977. On intraspecific competition for avian dispersers in tropical trees. American Naturalist, 111: 817-832.

Howe, H.F.; Van De Kerckhove, G. 1979. Fecundity and seed dispersal of a tropical tree. Ecology, 60 (1):180-189.

Howe, H.F;; Smallwood, J. 1982. Ecology of seed dispersal. Ann. Rev. Ecol. Syst., 13:201-228.

Huber, J. 1910. Matas e madeireiras Amazônicas. Boletim do Museu Paraense Emilio Goeldi, 6::91-225.

Izawa, K. 1975. Foods and feeding behavior of monkeys in the upper Amazon basin.

Primates, 16 (3):295-316.

Janzen, D.H. 1969. Seed-eaters versus seed size, number, toxicity and dispersal. Evolution, 23(1):1-27.

Janzen, D.H. 1970. Herbivores and the number of tree species in tropical forests. American Naturalist, 104:501-528.

Janzen, D.H. 1971. Seed predation by animals. Ann. Rev. of Ecol., 2, Sept.:465-492.

Janzen, D.H. 1975. Fruit and seed biology. In: Ecology of plants in the tropics. Ed. Edward Harold:26-34.

Kinzey, W.G. 1981. The titi monkeys, genus Callicebus. In: Coimbra-Filho, A.; Mittermeier, R.A. (eds) Ecology and Behavior of Neotropical Primates. Vol. I. Academia Brasileira de Ciências, Rio de Janeiro, Brazil:241-276.

Kinzey, W.G. 1992. Dietary and dental adaptations in the Pitheciinae. American Journal of Physical Anthropology, 88(4):499-514.

Kinzey, W.G.; Norconk, M.A., 1990. Hardness as a basic of fruit choice in two sympatric primates. American Journal of Physical Anthropology, 81(1):5-16.

Kinzey, W.G.; Norconk, M.A. 1993. Physical and chemical properties of fruit and seeds eaten by Pithecia and Chiropotes in Surinam and Venezuela. International Journal of Primatology, 14:207-227.

Macedo, M. 1977. Dispersão de plantas lenhosas de uma campina Amazônica. Acta Amazonica, 1: 69pp.

McKey, D, 1975. The ecology of coevolving seed dispersal systems. In: Coevolution of Animals and Plants. Gilbert \& Raven, P.H. eds. University of Texas Press., Texas. U.S.A: 159-191.

Mittermeier, R.A.; Van Roosmalen, M.G.M.. 1981. Preliminary observations on habitat utilization and diet in eight Surinam monkeys. Folia Primatol., 36:1-39.

Pennington, T.D. 1990. Sapotaceae. Monograph 52. Flora Neotropica. The New York Botanical Garden, New York: 770pp.

Peres, C.A. 1991, Ecology of mixed-species groups of tamarins in Amazonian terra firme forests. $\mathrm{Ph}$. D. dissertation, Department of Veterinary Anatomy, Cambridge University, Cambridge, U.K.: 239 pp.

Peres, C.A. 1993. Notes on the ecology of buffy saki monkeys Pithecia albicans Gray 1860: a canopy seed predator. American Journal of Primatology, 31(2): 129-140.

Peres, C.A. 1993. Diet and feeding ecology of saddle-back (Saguinus fuscicollis) and moustached ( $S$. mystax) tamarins in na Amazonian terra firme forest. J. Zool. Lond., 230:567-592.

Peres, C.A. 1994. Diet and feeding ecology of gray woolly monkeys (Lagothrix lagotricha cana) in central Amazonia: comparisons with other Atelines. International Journal of Primatology,15 (3): 333-372.

Pires, J.M.; Prance, G.T. 1985. The vegetation types of the Brazilian Amazon. Amazonia. G.T. Prance, ed. Oxford Pergamon Press: 109-145.

Prance, G.T. 1990. The floristic composition of the forests of central Amazonian Brazil. Four Neotropical Rainforests. G.H. Gentry, ed. London, Yale University Press.

Ramirez, M. 1988. The woolly monkeys, genus Lagothrix. In: Mittermeier, R.A.; Rylands, A.B.; Coimbra-Filho, A.; Fonseca, G.A.B. (eds). Ecology and 
Behavior of Neotropical Primates. Vol. II. World Wildlife Fund, Washington, D.C., U.S.A.:539-610.

Richards, P.W. 1996. The tropical rain forest. Cambridge University Press, Cambridge, U.K.

Ridley, H.N. 1930. The dispersal of plants throughout the world. L. Reeve. Ashford: 744 pp.

Rylands, A.B. No Date. Primates communities in Amazonian forests. Their habitats and food resources. Divisâo de Bioecologia, INPA, Manaus-AM, Brazil.

Setz, E. 1993. Ecologia alimentar de um grupo de parauacús (Pithecia pithecia chrysocephala) em um fragmento florestal na Amazônia central. Unpublished Ph.D. dissertation, Unicamp, University of São Paulo at Campinas-SP, Brazil: 237 pp.

Smythe, N. 1986. Competition and resource partitioning in the guild of neotropical territorial frugivorous mammals. Ann. Rev. Ecol. Syst., 17:169-188.

Snow, D.W. 1970. Evolutionary aspects of fruit-eating by birds. Ibis, 113:194-202.

Snow, D.W. 1981. Tropical frugivorous birds and their food plants: A world survey. Biotropica, 13(1):1-14.

Snowdon, T.S.; Soini, P. 1988. The tamarins, genus Saguinus. In: Mittermeier, R.A.; Rylands, A.B.; Coimbra-Filho, A.; Fonseca, G.A.B.(eds) Ecology and Behavior of Neotropical Primates. Vol. II. World Wildlife Fund, Washington, D.C., U.S.A.: 223-298.

Soini, P. 1988. The pygmy marmoset, genus Cebuella. In: Mittermeier, R.A.; Rylands, A.B.; Coimbra-Filho, A.; Fonseca, G.A.B.(eds) Ecology and Behavior of Neotropical Primates. Vol. II. World Wildife Fund, Washington, D.C., U.S.A.: 79-129.

Stevenson, M.F.; Rylands, A.B. 1988. The marmosets, genus Callithrix. In: Mittermeier, R.A.; Rylands, A.B.; Coimbra-Filho, A.; Fonseca, G.A.B.(eds) Ecology and Behavior of Neotropical Primates. Vol. II. World Wildlife Fund,
Washington, D.C., U.S.A.:131-142.

Van Der Pijl, L. 1982. Principles of disersal in higher plants. Springer-Verlag, Berlin, Germany.

Van Roosmalen, M.G.M. 1985. Fruits of the Guianan Flora. Institute of Systematic Botany, Utrecht University, and Silicultural Department of Wageningen Agricultural University, Wageningen, The Netherlands: 483 pp.

Van Roosmalen, M.G.M. 1985. Habitat preferences, diet, feeding strategy and social organization of the black spider monkey (Ateles paniscus Linnaeus 1758) in Suriname. Acta Amazônica, Vol. 15 4) supl.: $238 \mathrm{pp}$.

Van Roosmalen, M.G.M.; Mittermeier, R.A.; Milton, K. 1981. The bearded sakis, genus Chiropotes. In: Coimbra-Filho, A.; Mittermeier, R.A. (eds) Ecology and Behavior of Neotropical Primates. Vol. I. Academia Brasileira de Ciências, Rio de Janeiro, Brazil: 419-441.

Van Roosmalen, M.G.M.; Mittermeier, R.A.; Fleagle, J.G. 1988. Diet of the northern bearded saki (Chiropotes satanas chiropotes): a neotropical seed predator. Amer. J. of Primatology, 14:11-35.

Van Roosmalen, M.G.M.; Klein, L. 1988. The spider monkeys, genus Ateles. In: Mittermeier, R.A.; Rylands, A.B.; Coimbra-Filho, A.; Fonseca, G.A.B.(eds) Ecology and Behavior of Neotropical Primates. Vol. II. World Wildlife Fund, Washington, D.C., U.S.A.:455-537.

Van Roosmalen, M.G.M.; Bardales, M.; Del Pilar Diaz; Cruz Gomes Garcia, O.M. 1996. Frutos da Floresta Amazônica. Parte I: Myristicaceae. Acta Amazonica, 26(4): 209-264.

Wheelwright, N.T. 1985. Competition for dispersers, and the timing of flowering in a guild of tropical trees. Oikos, 44: 465-77.

Wheelwright, N.T. 1988. Fruit-eating birds and bird-dispersed plants in the tropics. Tree, Vol. 3(10).

Wright, P. 1981. The night monkeys, genus Aotus. In: Coimbra-Filho, A.; Mittermeier, 
R.A. (eds). Ecology and Behavior of Neotropical Primates. Vol. I. Academia

Brasileira de Ciências, Rio de Janeiro, Brazil: 221-240. 